\title{
Vascular access for haemodialysis : long term results, costs and the effects of percutaneous transluminal angioplasty
}

Citation for published version (APA):

Burger, H. (1994). Vascular access for haemodialysis : long term results, costs and the effects of percutaneous transluminal angioplasty. [Doctoral Thesis, Maastricht University]. Rijksuniversiteit Limburg. https://doi.org/10.26481/dis.19940616hb

Document status and date:

Published: 01/01/1994

DOI:

10.26481/dis.19940616hb

Document Version:

Publisher's PDF, also known as Version of record

Please check the document version of this publication:

- A submitted manuscript is the version of the article upon submission and before peer-review. There can be important differences between the submitted version and the official published version of record.

People interested in the research are advised to contact the author for the final version of the publication, or visit the DOI to the publisher's website.

- The final author version and the galley proof are versions of the publication after peer review.

- The final published version features the final layout of the paper including the volume, issue and page numbers.

Link to publication

\footnotetext{
General rights rights.

- You may freely distribute the URL identifying the publication in the public portal. please follow below link for the End User Agreement:

www.umlib.nl/taverne-license

Take down policy

If you believe that this document breaches copyright please contact us at:

repository@maastrichtuniversity.nl

providing details and we will investigate your claim.
}

Copyright and moral rights for the publications made accessible in the public portal are retained by the authors and/or other copyright owners and it is a condition of accessing publications that users recognise and abide by the legal requirements associated with these

- Users may download and print one copy of any publication from the public portal for the purpose of private study or research.

- You may not further distribute the material or use it for any profit-making activity or commercial gain

If the publication is distributed under the terms of Article 25fa of the Dutch Copyright Act, indicated by the "Taverne" license above, 


\section{Vascular Access for Haemodialysis}

Long term results, costs and the effects of percutaneous transluminal angioplasty 


\section{VASCULAR ACCESS FOR HAEMODIALYSIS}

Long term results, costs and the effects of percutaneous transluminal angioplasty

\section{PROEFSCHRIFT}

ter verkrijging van de graad van doctor aan de Rijksuniversiteit Limburg te Maastricht, op gezag van de Rector Magnificus,

Prof. Dr. H. Philipsen, volgens het besluit van het College

van Dekanen

in het openbaar te verdedigen

op donderdag, 16 juni 1994, om 16.00 uur

door

Hendrik Burger

geboren te Alkmaar 


\section{Promotores:}

Prof. dr. G. Kootstra

Prof. dr. P.J.E.H.M. Kitslaar

Beoordelingscommissie:

Prof. dr. J.P. van Hooff (voorzitter)

Dr. A. Ament

Prof. dr. B. Janevski

Prof. dr. R.A. Janknegt

Prof. dr. H. van Urk, Erasmus Universiteit Rotterdam 
"We believe to be able to keep patients suffering from uraemia and anuria alive so long as bloodvessels for puncture are available"

W.J. Kolff, 1944

"Although vascular access surgery does not have the drama and glamour of major cardiovascular surgery, for the individual patient, vascular access is a lifeline"

M. Haimov, 1987

"In the last 20 years, the many and most delicate techniques involved in creating and maintaining vascular access have become significant and demanding parts of one of the most rapidly growing specialties, vascular surgery."

W.F. Barker, 1988

Aan de dialyse patiënten, die bebben leren leven met bun kwetsbare toegang tot de bloedbaan.

Aan mijn ouders.

Aan mijn vrouw en kinderen. 
De uitgave van dit proefschrift is financieel gesteund door bijdragen van de Nier Stichting Nederland en de Stichting Ontwikkelingsfonds Drechtsteden Ziekenhuis.

Voorts hebben bijgedragen W.L. Gore \& Ass., Cadsand Medica B.V., Dupont de Nemours Nederland B.V., Sigma Medical B.V., Cobe B.V., Glaxo Nederland B.V., Schering Nederland B.V., Hoechst Holland N.V. Pharma, Johnson \& Johnson Medical B.V., Medicor Nederland B.V., Gambro B.V., Baxter B.V. en Hospal B.V.

C.IP.GEGEVENS KONINKUJKE BIBLIOTHEEK, DEN HAAG

Burger. Hendrik

Vascular access for haemodialysis : long term results, costs and the effects of percutaneous transhuminal angioplasty / Hendrik Burger. - [S.I. : s.n. ], - Ill. Proefschrift Maastricht. - Met lit. opg. - Met samenvatting in het Nederlands. ISBN 90.9007278 .0

Trefw: hemodialyse

O H. Burger, Dordrecht, 1994. All rights reserved. 


\section{CONTENTS}

List of abbreviations

viii

PREFACE

CHAPTER 1

General introduction

Historical notes on vascular access surgery. Vascular access in the nineties: types of vascular access, complications associated with them and treatment of the complications. Percutaneous transluminal angioplasty for vascular access

CHAPTER 2.

A survey of vascular access in the Netherlands

Nephrology Dialysis Transplantation 1991; 6: 5-10

\section{CHAPTER 3}

Percutaneous transluminal angioplasty improves longevity in fistulae and shunts for haemodialysis

Nephrology Dialysis Transplantation 1990; 5: 608.611

CHAPTER 4

Survival of arteriovenous fistulae and shunts for haemodialysis European Journal of Surgery (in press)

CHAPTER 5

Cost analysis of vascular access for haemodialysis

Submitted

CHAPTER 6

General discussion and conclusions

CHAPTER 7

Summary

CHAPTER 8

Samenvatting

Literature

Dankwoord

Curriculum vitae

Appendix 


\title{
List of abbreviations
}

\author{
A. $\mathrm{V}$ : arteriovenous \\ CAPD : continuous ambulant peritoneal dialysis \\ CCPD : continuous cyclic peritoneal dialysis \\ Dfl : Dutch guilder \\ ESRD : end-stage renal disease \\ n : number \\ No : number \\ PTA : percutaneous transluminal angioplasty \\ PTCA : percutaneous transluminal coronary angioplasty \\ PTFE : (expanded) polytetrafluoroethylene \\ USD : United States dollar
}




\section{Preface}

The loss of function of the kidneys, called end-stage renal disease (ESRD), can be treated by haemodialysis, peritoneal dialysis, or kidney trans. plantation. Haemodialysis was practiced with success for the first time by Kolff [1] on 17 March 1943 at Kampen in the Netherlands. He had constructed an artificial kidney with the technical help of Berk. Access to the circulation proved to be an insurmountable problem after twelve dialyses and for the last five accesses the help of a surgeon was required.

To make long term haemodialysis feasible for a patient, a permanent access to his circulation is needed. This access, which has been called vascular access or angioaccess, is the subject of this thesis.

On 1 January 1992, the Netherlands had a population of 15129150 , 6447 of whom were on dialysis or living with a functioning transplant ( 1 out of every 2347 men or women) ${ }^{1}$ Out of a group of 3311 patients on dialysis and being treated in 53 centres, including some centres for home dialysis, 2447 were on haemodialysis and 864 on peritoneal dialysis. All patients on haemodialysis require a vascular access. To establish and maintain this vascular access, about 0.8 surgical interventions per patient per year are needed.

After many trials and errors, Quinton et al. succeeded in 1960 [2] in constructing a permanent vascular access, that made it possible to offer prolonged treatment for ESRD. They created a connection between an artery and a vein with Teflon and silicon rubber tubing. This external arteriovenous (A.V) shunt could be used several times a week and remained patent for a longer period. Other and more effective types of vascular access have been found since, especially the A.V fistula developed by Brescia et al. in 1966 [3]. The general term "shunt" is still used for all sorts of accesses in which an artery and a vein are linked together to provide an access to the circulation of the blood. The term includes the subcutaneous kind, which requires skin puncture for each dialysis and the transcutaneous kind, which permanently penetrates through the skin.

Another treatment for ESRD, peritoneal dialysis, was at first only practical for acute dialysis during a limited time period [4]. Latter a

\footnotetext{
' Newsletter Registration Renal Replacement Therapy the Netherlands. Foundation RENINE, Rotterdam, 1992
} 
permanent access to the peritoneal cavity was developed and continuous ambulant peritoneal dialysis (CAPD) and its variants among them continuous cyclic peritoneal dialysis (CCPD), are now practical alternatives [5]. It is estimated that more than a million people all over the world are being kept alive by means of haemodialysis and peritoneal dialysis.

The third and most desirable treatment for ESRD, kidney transplantation, has become a standard procedure and gives the best results with regard to quality of life [6]. Yet, kidneys for transplantation cannot be obtained in sufficient numbers, a compatible kidney is often not available and not all patients are suitable for transplantation. Also, a number of transplanted kidneys are rejected by patients, in spite of modern immunosuppressive medication and patients then have to rely on dialysis again.

The lifetime of an A.V shunt is threatened by several complications, the most serious being stenosis. The diagnosis and treatment of stenosis of shunts is vital for the maintenance of vascular access. Balloon dilatation, percutaneous transluminal angioplasty (PTA), a relatively new vascular intervention technic, has been proven to be quite useful in vascular access for the treatment of stenotic complications.

The present thesis consists of studies about the state of vascular access surgery for haemodialysis and its results in the Netherlands, as well as the influence of PTA on the number of surgical interventions required to maintain vascular access, the survival of shunts and the costs of shunt surgery.

\section{The aims of this study are:}

1. To establish the state of vascular access for haemodialysis in the Netherlands.

2. To investigate the long term results of the different types of vascular access and the effect of PTA on the results.

3. To investigate the effects of the routine application of PTA for treatment of stenotic complications in vascular access on the number of surgical interventions needed to maintain an adequate vascular access for haemodialysis.

4. To investigate the costs of vascular access surgery and PTA and the effects of routine application of PTA on the total costs of vascular access. 


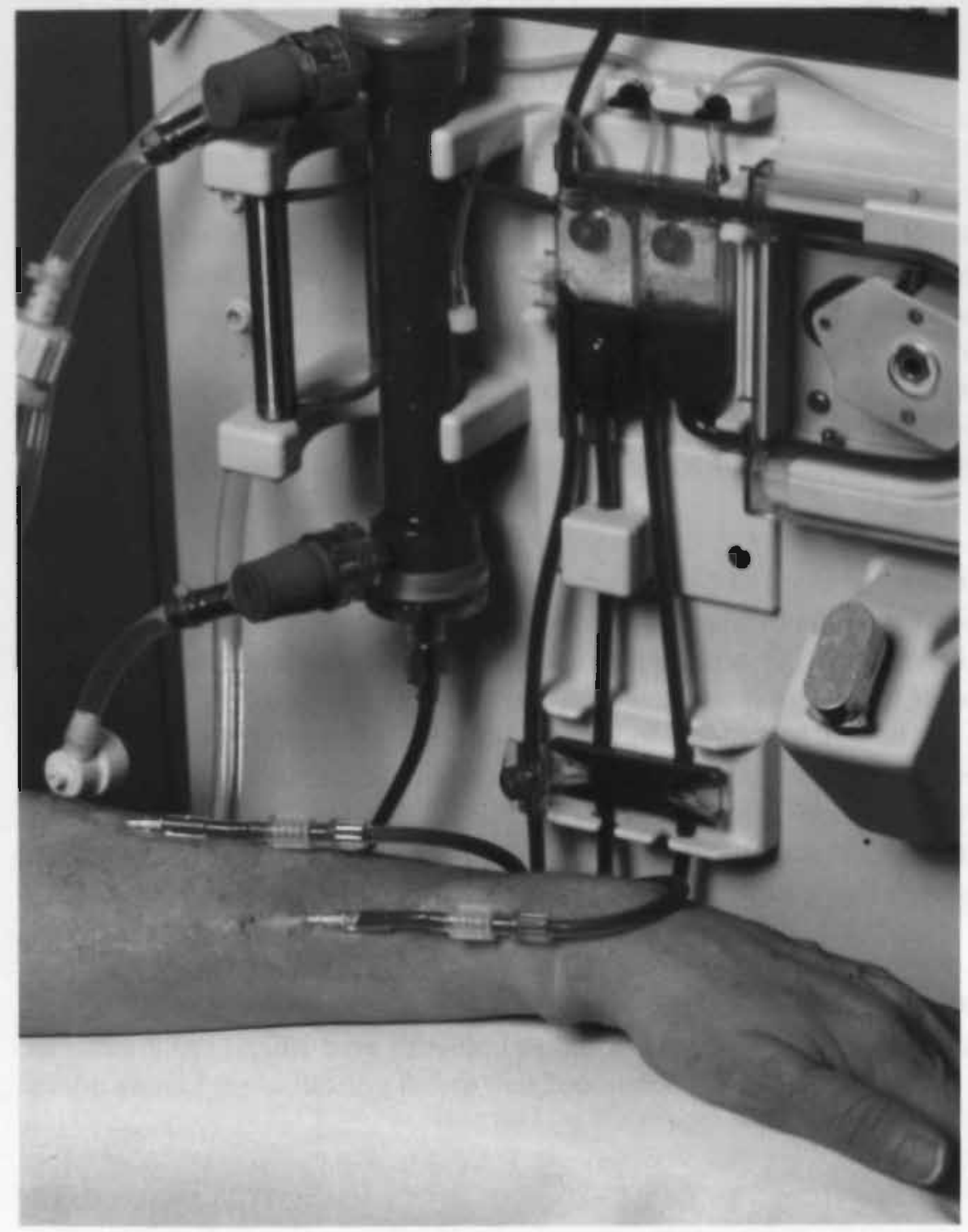

Patient connected to a dialysis macbine by way of an arteriovenous fistula. 



\section{General Introduction}

Access to the blood circulation is a precondition for haemodialysis. Vascular access surgery concerns itself with creating and maintaining such an access. It is called a shunt or dialysis shunt; the Index Medicus refers to it as "arteriovenous shunt, surgical". More specifically the word "shunt" is often reserved for the partly external arteriovenous (A.V) shunt. The entirely internal A.V shunt complex is called an A.V fistula. The term blood access also covers the central venous or arterial catheters which can be used for haemodialysis.

Publications about vascular access have appeared in abundance over the years since 1960. Monographs on vascular access surgery have been published, among them the books of Bell and Calman [7], Haimov [8] and Wilson [9], an issue of Current Problems in Surgery by Marx, Landmann and Harder [10] and the atlases of Rubio and Farrell [11] and Ota [12]. In some atlases and handbooks on vascular surgery chapters on vascular access, as well as dialysis contain good overviews by authorities in their field $[13,14]$. In the Netherlands, theses by Bast [15], Slooff [16], Zijlstra [17] and Tordoir [18] have highlighted aspects of vascular access.

International congresses on vascular access surgery in 1982 and 1990 in Maastricht $[19,20]$ have provided a platform for establishing the state of the art and for indicating future developments.

\section{HISTORICAL NOTES}

The history of successful surgery for a permanent vascular access for haemodialysis started in 1960 with the construction of an A.V shunt by Quinton et al. [2]. Surgery in the service of haemodialysis was first performed by Kehrer at the request of Kolff on 6 April 1943 at Kampen in the Netherlands. The difficult and fateful endeavors to prolong the first effective haemodialysis in a human being are well described by Kolff in his articles in the Dutch medical press in $1943[21,22]$ and 
in Acta Medica Scandinavica in 1944 [1] as well as in his thesis in 1946 [23].

One is tempted to recall Carrel's first A-V anastomoses in 1902 [24]. He and Guthrie probably did not foresee the use of these anastomoses for a permanent access to the superficial veins, but they certainly did see the possibilities of transplantation surgery and they immediately did some kidney autotransplantations [25]. Brescia et al. were able to build on their experience when they constructed an A.V fistula at the wrist to provide a permanent access to the circulation for haemodialysis in 1966.

The founding of centres for haemodialysis in the sixties and seventies required adequate vascular access surgery and so from modest beginnings the latter has become an established branch of vascular surgery. While in most patients vascular access can be established for long periods without many interventions, a number of patients requires several operations and persistent efforts to sustain an access or create new ones.

\section{VASCULAR ACCESS IN THE NINETIES}

Vascular access, defined as a temporary or permanent access to the blood circulation, is an important condition for much diagnostic and therapeutic medical work. It ranges from a simple intravenous infusion or a venous puncture to draw blood for analysis to central venous carheters, access ports for chemotherapy and A.V fistulas and shunts, meant to provide a permanent access for haemodialysis. The last two forms of access usually call for surgical intervention. Surgery that concerns itself with creating and maintaining access to the blood circulation is called vascular access surgery.

Access surgery for haemodialysis has become more sophisticated than it used to be because a wide range of possibilities of gaining and maintaining access to the circulation has become available.

The first choice for a vascular access for haemodialysis is an autogenous distal A.V fistula at the wrist, as described by Brescia et al. [3]. Usually this fistula must ripen for 3-6 weeks before it can be used and, therefore, it is important to make such a fistula in time. When an immediate dialysis is wanted, a central venous catheter is placed. Shaldon pioneered the catherisation of the femoral vein [26]. Later the subclavian vein became popular and lately the jugular vein is preferred. The alternative acute access, an A.V shunt, preferably in the leg in order to spare the arm vessels, is presently used less frequent but is not obsolete. 
When a primary or first choice access is not possible, other accesses can be constructed that function well [27]. These so-called secondary or second choice accesses include more proximal A.V fistulas, graft A.V fistulas and implantable systems. Second choice accesses can be very useful but they should, indeed, be second choice because they are associated with more complications and their survival is inferior to first choice accesses. The problem is knowing when a first choice access has a good chance functioning well. Still, when the patient and his physician are well motivated, it is worthwhile trying to make a first choice access. The patient may need an access for years and it is wise to conserve more proximal vessels for the future.

Several varieties of the A.V shunt and fistula have proven to be useful in clinical practice.

\section{The A.V sbunt}

The A.V shunt is based on the simple principle of cannulation of an artery and a vein in a limb connected by tubing that perforates the skin. For dialysis, the tubes are disconnected outside the skin and linked to the artificial kidney. This method, already explored by Kolff and Alwall

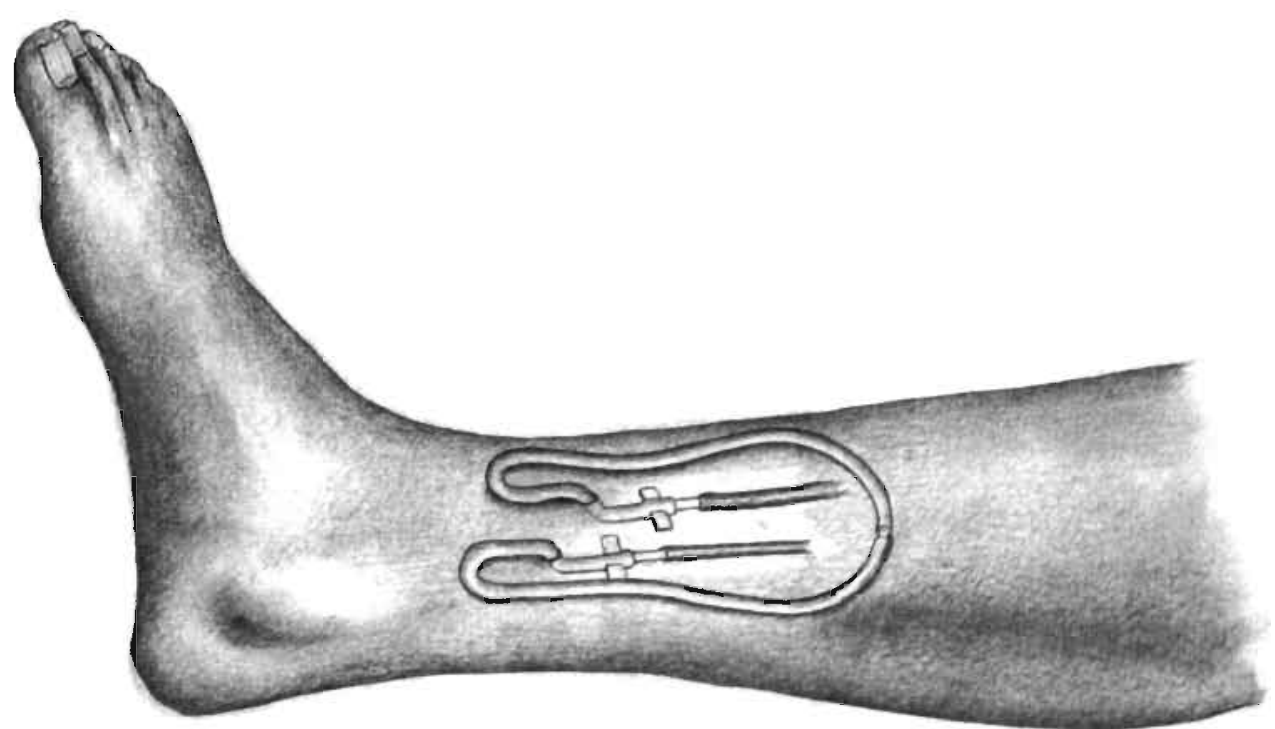

Figure 1. The A-V shunt in the leg. The Scribner shunt in the Ramirez variation, with an external bend. 


\section{Chapter 1}

[28], was made practicable by Quinton et al. $[2,29]$ by using Teflon cannulas and Silastic tubing. Ramirez suggested a variation of the Scribner A.V shunt [30] (Fig. 1). The Ramirez shunt does not have a subcutaneous bend for better fixation like the original Scribner shunt, but it has straight subcutaneous tubing with wings for fixation which facilitates the passage of catheters to treat complications [17].

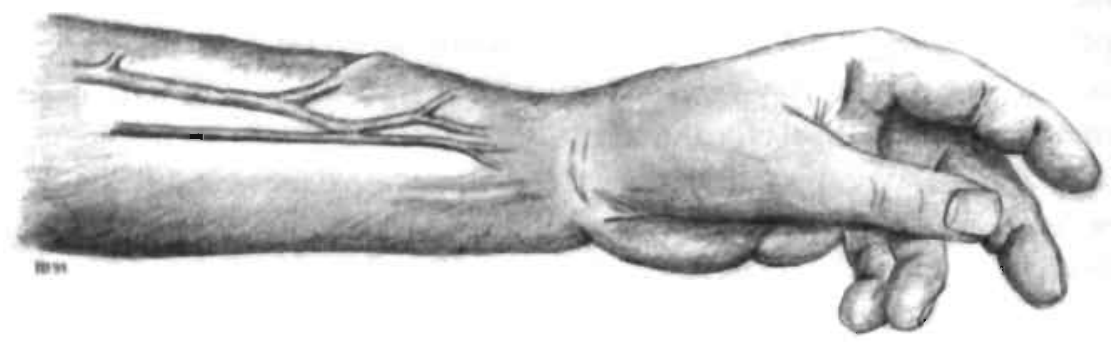

Figure 2. The radiocepbalic distal A V fistula side to side in the arm, the Cimino fistula.

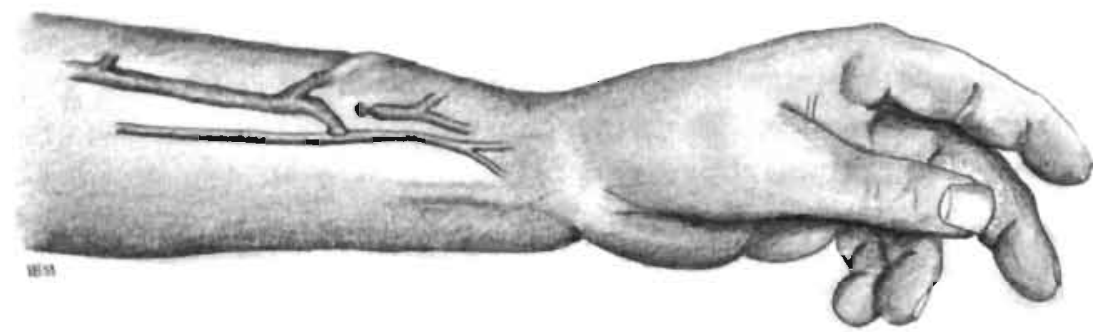

Figure 3. The radiocepbalic distal A.V fistula side to end in the arm, the Cimino fistula.

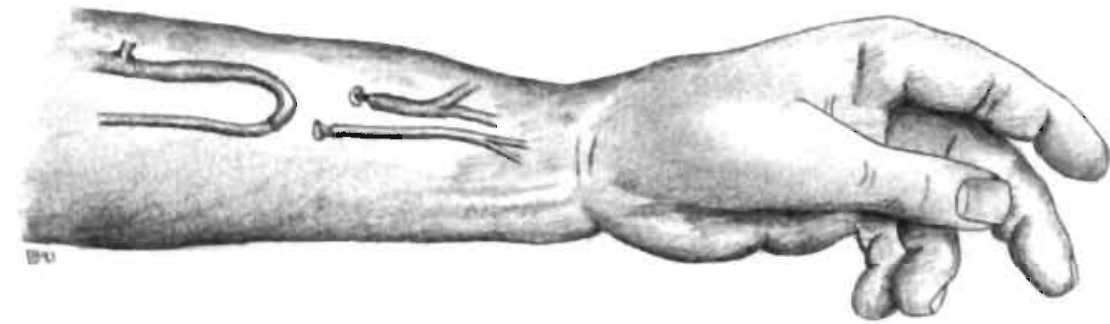

Figure 4. The radiocepbalic distal A.V fistula end to end in the arm, a Cimino fistula ivariation 
To create a useful A-V fistula a connection is made between an artery and a superficial vein, which results in perfusion of the veins with a strong blood flow. Under arterial pressure the veins tend to dilate, allowing an easier puncture of the veins. Repeated puncture of the superficial veins is quite possible and provides a flow of blood that is sufficient for regular haemodialysis. However, in the course of time, stenoses do occur in the arterialised veins. Brescia et al. first reported on the A-V fistula between the radial artery and the cephalic vein at the wrist for vascular access in 1966 [3] (Fig. 2-4). Several variations have been found useful, but essentially this same $\mathrm{A} \cdot \mathrm{V}$ fistula has proven to be the best access available [31]. Some surgeons have reported good or even better results for a still more distal A.V fistula, the anatomical snuffbox, the "tabatière anatomique" fistula [32].

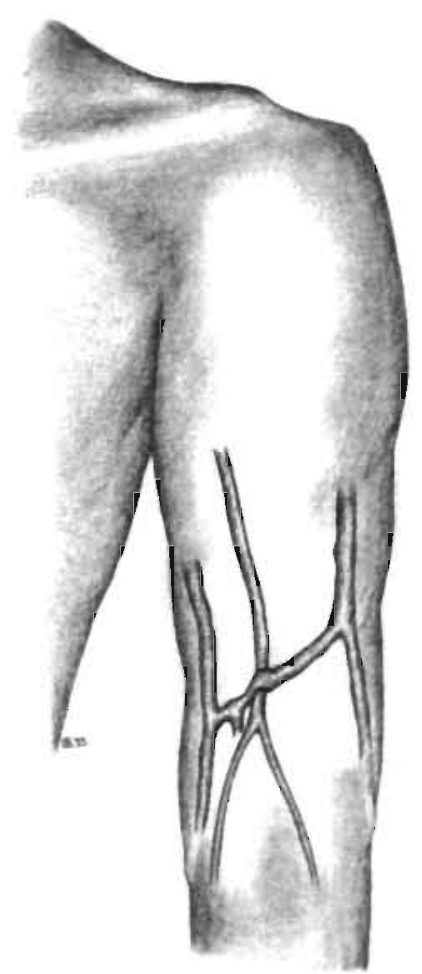

Figure 5. The autogenous A.V fistula at the elbow between the bracbial artery and a cubital vein. A side to side variation. 


\section{Cbapter 1}

\section{The proximal A-V fistula}

When a distal fistula fails, a more proximal fistula is sometimes possible in the elbow region [33, 34] (Fig. 5). This A.V fistula often supplies a good flow of blood. Whether this second choice A.V fistula is useful depends on whether the superficial veins are sufficient and whether the circulation to the hand is not compromised.

\section{The graft A-V fistula}

Whenever there are not enough superficial veins available, a superficially placed graft between an artery and a vein can provide a good access (Fig. 6). The saphenous vein as an autotransplant (May et al. 1969) [35] has been used with good results by a number of surgeons [36]. Others have reported negative results [37] and sufficient veins for grafting may not always be available. In general the saphenous vein is still used, albeit to a limited extent, for $\mathrm{A} \cdot \mathrm{V}$ graft fistulas. In the late seventies, the bovine artery graft was extensively used [37], but it has since been discarded because there were too many complications [38]. Extended polytetrafluoroethylene (PTFE) grafts have now been in use for more than 10 years and are probably the most popular grafts these days [39,

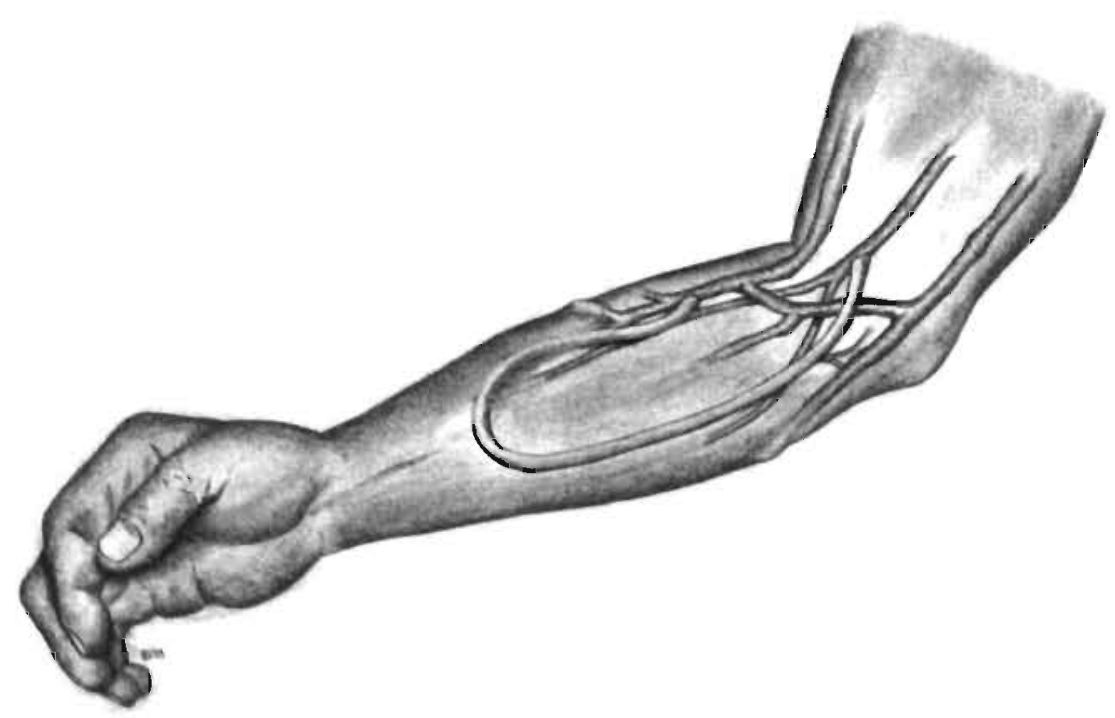

Figure 6. The graft A.V fistula in the arm. A PTFE loop witb anastomoses at the elbow. 
40]. The homologous saphenous vein graft, a saphenous vein from another person that has undergone a process of denaturation to prevent immune rejection, seems a reasonable alternative to the autologous vein [41].

\section{Implantable systems}

Implantable vascular access systems with a transcutaneous connection, that can easily be attached to the artificial kidney have been used with varying degrees of success (Fig. 7). Most experience has been gained with Biocarbon ${ }^{*}[42]$ and Hemasite systems ${ }^{\circledR}$ [43]. They can function well, but because they perforate the skin they are susceptible to infection. New systems are being tried out, but none is, as yet, regularly employed for clinical haemodialysis.

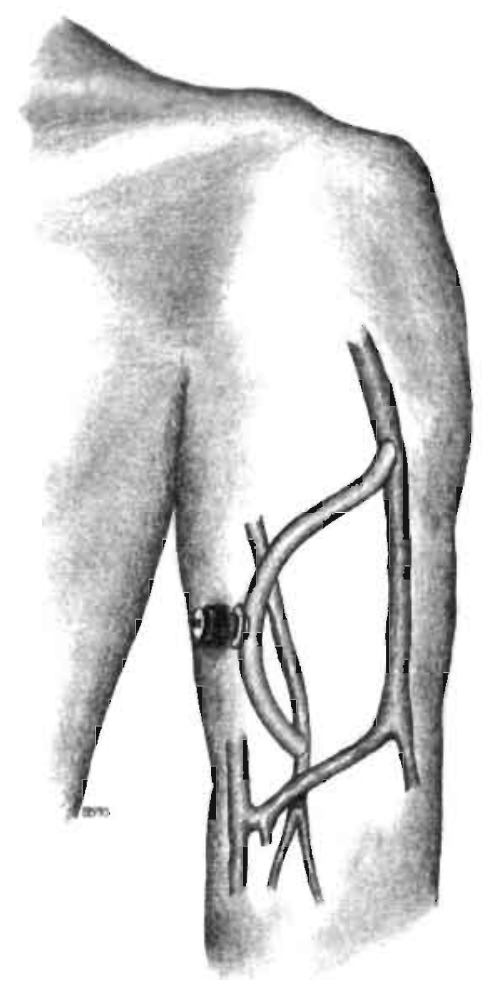

Figure 7. An external vascular access device (Biocarbon? ). The device, fixed on a MTFE grafi wbich is anastomosed with the brachial artery and the cephalic vein, offers access by using a special plug. 
Good surveillance of vascular access means careful daily monitoring of blood flow by auscultation by the patient or the attending medical staff and observation of signs of infection, abnormal dilatation of veins and signs of ischemia or venous hypertension. During dialysis, blood flow and venous pressure must be monitored. Vacuum suction with a blood flow of more than $300 \mathrm{ml} / \mathrm{min}$ and a venous pressure higher than 150 $\mathrm{mm} \mathrm{Hg}$ during three consecutive dialysis sessions must be regarded as abnormal and is often indicative of stenotic problems within the vascular access [44]. Recirculation of the blood in the shunt may also indicative of stenoses and a monthly recirculation test is sensible. New dialysis equipment also allows one to measure arterial pressures.

\section{Diagnostic metbods to evaluate access surgery}

\section{Invasive methods}

Angiography of a vascular access is the preferred method for imaging and remains the golden standard $[45,46]$. To perform angiography from various angles is not easy. The high-pressure inflow with a low-pressure outflow demands a special technique. To make an angiogram immediately after dialysis obviates a new puncture, but puts a certain amount of pressure on the radiology department. Conventional film techniques are preferred [17], although some report advantages for digital subtraction angiography [47].

\section{Noninvasive methods}

Duplex scanning, combining the use of ultrasonic vessel imaging and pulsed Doppler examination, has proven to be useful in diagnosing, stenoses in a vascular access [18]. The colour Doppler technique may improve that method by visualizing the direction of the blood flow in colour [48].

\section{Complications of vascular access}

From the time it was first used until today, the most serious complications of vascular access have been thrombosis, stenosis and infection [49]. To these must be added prolonged bleeding, decubitus, venous hypertension, aneurysm, steal syndrome, subclavian vein thrombosis $[50,51]$ and accidental disconnection of an external shunt. Prevention of these complications and, when possible, early treatment may save a vascular 
access. Prevention includes performing the operation in a meticulous way, with careful assessment of the blood flow on completion of the anastomosis and after closure of the skin, anticoagulant therapy when needed and prompt reintervention in the case of thrombosis.

\section{Treatment of the most serious complications of vascular access}

\section{Tbrombosis}

Three methods are available to treat thrombosis: surgical thrombectomy, thrombolysis and percutaneous thrombectomy. While postponing treatment for a few hours is acceptable and a thrombectomy can be attempted even after days of occlusion, prompt treatment is the best choice. Thrombolysis of Scribner shunts with streptokinase has been used for a long time and with good results. A Scribner shunt can also be cleared with the help of catheters. Surgical thrombectomy is usually still the method of choice for $\mathrm{A} \cdot \mathrm{V}$ fistulas. Thrombectomy by percutaneous catherization is sometimes also successful with A-V fistulas. Percutaneous catheter techniques for thrombolysis, combined with balloon dilatation of stenoses, possibly promise good results and do not require surgical interventions [52].

Lately, the frequency of thrombotic complications in vascular access for end-stage renal disease (ESRD) has risen considerably, maybe because of the use of erythropoietin in dialysis patients. This new medicine not only raises the hemoglobin level but also restores the impaired coagulation of the ESRD patient $[53,54]$. A more active thrombosis prophylaxis is warranted for patients receiving erythropoietin.

Although thrombosis may occur without serious endovascular stenosis, it is always wise to search for a stenosis in the event of a shunt thrombosis. Prevention of thrombosis with anticoagulants must also be considered for patients with heterologous grafts, Scribner A.V shunts and high hemoglobin levels, as well as for patients with a manifest disposition for thrombosis. Coumarin derivates (Sintrom mitis ${ }^{\circledR}$ ), acetyl salicylic acid and dipyridamol (Persantin $\left.{ }^{(}\right)$[55] can be used; the latter two may be especially helpful when one does not want to risk bleeding.

\section{Stenosis}

Stenosis is the most serious complication of vascular access. It is caused by the repeated punctures and by the abnormal bloodflow, which results in hyperplasia of the intima. When caused by the abnormal bloodstream, this intimal hyperplasia typically occurs just proximal of the A-V anastomosis in Cimino fistulas, at the graft-venous anastomosis of graft A.V 


\section{Chapter 1}

fistulas and in the efferent vein of graft A.V fistulas. Repeated puncture of the vessel wall may lead to dilatation and the formation of aneurysms, but most often it leads to stenosis [18].

Two methods of treatment are available: surgical and radio-interventional. The surgical treatment can be a dilatation operation with the help of a patch, such as autologous vein or PTFE. Sometimes a bypass or an interposition is a better solution to the problem of stenosis, utilizing a transplanted vein or a PTFE graft. The radio-interventional method - the balloon dilatation - is still gaining ground, as more radiologists acquire experience and enthusiasm for the method. It is a more patientfriendly method and the results justify continuation [56].

\section{Infection}

Infection of a vascular access poses a threat to the access itself and to the patient. The skin-perforating accesses like the Scribner A.V shunt are most prone to infection. The heterologous graft A.V fistulas are also susceptible to infection. Prophylactic and therapeutic use of antibiotics may prevent an infection and save an access $[51,57]$. Not only very strict surgical discipline is needed to help to prevent infection but also discipline on the part of the patient and of the haemodialysis department. Infected grafts may have to be taken out. Infected catheters demand a very active antibiotic regimen and often removal of the catheter [58].

\section{Vascular access for acute baemodialysis}

Acute haemodialysis demands immediate vascular access. Catheters are used in the femoral vein (Shaldon) [26], the subclavian vein [59], or the internal jugular vein [60] to provide access in acute situations for patients on chronic haemodialysis or for patients with a rapidly developing uremia. The subclavian vein catheter and the internal jugular vein catheter have also been used as a semipermanent or even a permanent access [57]. Their associated complications - notably stenosis, thrombosis and infection of central veins - are more serious than the same complications in more distal veins.

While an A.V shunt of the Scribner type is useful as an acute and semipermanent access, in most dialysis departments the access of choice for acute and semipermanent access is a catheter in the subclavian vein [61]. A catheter in the femoral vein has fewer serious complications, but is far less practical as an access for more than a few days. The internal jugular vein has been used more and more lately as a good access vessel for catheters $[62,63]$. Over the past years, there has been a growing 
awareness of the complications of upper central venous catheters [57, 64-66], especially thrombosis. An obstruction of the subclavian vein obviates the possibilities for a vascular access in the corresponding arm [67].

\section{Percutaneous transluminal angioplasty ( PTA)}

The technique of dilating stenoses in blood vessels, often called trans. luminal angioplasty, was originally developed by Dotter and Judkins. [68] and Grüntzig and Hopff [69]. Dilatation can be accomplished during an operation or percutaneously. Percutaneous dilatation is less invasive and tends to be more patient-friendly.

Percutaneous transluminal coronary angioplasty (PTCA), balloon dilatation for arteriosclerotic stenosed coronary arteries, has acquired a wide reputation, making coronary heart surgery sometimes superfluous. In peripheral arteries too balloon dilatation is regularly used with success. The right indications for PTA and PTCA are still a matter of debate, but a consensus is developing [70].

The fibrotic stenoses that tend to develop in the arterialised veins, grafts and anastomoses of A-V fistulas and shunts can also be dilated, often percutaneously. This method is increasingly used for vascular access $[17,54,71-73]$.

\section{REFERENCES TO THE PREFACE AND CHAPTER 1}

1. Kolff WJ, Berk HT, Welle ter $M$, Ley van der AJW, Dijk van EC, Noordwijk van J. The artificial kidney: a dialyser with a great area. Acta Med Scand 1944; 67: 122. 134

2. Quinton W, Dillard D, Scribner BH. Cannulation of bloodvessels for prolonged hemodialysis. Trans Am Soc Artif Intern Organs 1960; 6: 104-113.

3. Brescia MI, Cimino JF, Appel K, Hurwich JB. Chronic Hemodialysis using venipuncture and a surgically created arieriovenous fistula. New Eng J Med 1966; 275: 1089-1092.

4. Boen ST, Mion CM, Curtis FK, Shilipetar G. Periodic peritoneal dialysis using the repeated puncture technique and an automatic cycling machine. Trans Am Soc Arif Intern Organs 1964; 10: 409-414.

5. Lindblad A, Novak JW, Nolph KD eds. Continuous ambulatory peritoneal dialysis in the USA Final report of the National CAPD Registry 1981-1988. Dordrecht: Kluwer, 1989.

6. Kootstra G. Quality-of -life assessment in end-stage renal disease. Theor Surg 1992; 7:24.26.

7. Beil PRF, CaIman KC. Surgical aspects of haemodialysis. Edinburgh: Churchill livingstone, 1974.

8. Haimov M ed. Vascular Access, a Practical Guide. New York: Futura Publishing Company, 1987 
9. Wilson SE. Vascular Access Surgery. 2nd ed., Chicago: Year Book Medical Publishers, 1988.

10. Marx AB, Landmann J, Harder FH. Surgery for vascular access. Current Problems in Surgery 1990; 27: 1-48.

11. Rubio PA, Farrell EM. Atlas of Angioaccess Surgery. Chicago: Year Book Medical Publishers, 1983.

12. Ota K. An atlas of vascular access. Edinburgh: Churchill Livingstone, 1987.

13. Effeney DJ, Stoney RJ. Acute and chronic access to the circulation. In Wylie's atlas of vascular surgery, volume VI. Philadelphia: J.B. Lippincott, 1993: 72-113.

14. Bell PRF, Veitch PS. Vascular access for haemodialysis. In: Clinical dialysis. Nissenson AR, Fine RN, Gentile DE eds. London: Prentice Hall Int., 1990: 26-44.

15. Bast T. De toegang tot de bloedbaan voor geregelde dialyse behandeling [Dissertation]. Amsterdam, 1974.

16. Slooff MJH. Secondary access surgery for hemodialysis and chemotherapy [Dissertation], Groningen, 1981.

17. Zijlstra IJ. Percutaneous transluminal angioplasty in vascular access for hemodialysis. A manual for the radiologist [Dissertation]. Utrecht, 1989.

18. Tordoir JHM. Noninvasive diagnostic studies of arteriovenous fistulas for hemodialysis [Dissertation]. Maastricht, 1989.

19. Kootstra G, Jorning PJG eds. Access Surgery. Proceedings of the international congress on access surgery, Maastricht 1982. Lancaster: MTP Press Lid,

20. Tordoir JHM, Kitslaar PJEHM, Kootstra G eds. Progress in access surgery. Proceedings of the 2nd international congress on access surgery, Maastricht 1990. Maastricht: Datawyse, 1990.

21. Kolff WJ, Berk HTJ. De kunstmatige nier: een dialysator met groot oppervlak. Geneesk Gids 1943: 21: $409-421$.

22. Kolf W], Berk hiij. De Kunstmatige nier. Een dialysator met groot oppervlak. Ned Tijdschr Geneeskd 1943: 87: 1684 1688.

23. Kolff W]. De kunstmatige nier [Dissertation]. Kampen: Kok, 1946.

24. Carrel A. La technique opératoire des anastomoses vasculaires et les transplantations des viscères. Lyon Med 1902; $98: 859$.

25. Carrel A. Guthrie CC. Functions of a transplanted kidney. Science 1905; 22: 473.

26. Shaldon S, Chiandussi L. Higgs, B. Haemodialysis by percutaneous catheterization of femoral artery and vein with regional heparinisation. Lancet 1961; 2: 857.859

27. Kootstra G. Secondary procedures for A.V fistula failure. Proc Eur Dial Transplant Assoc 1982; 19: 99.105.

28. Alwall N, Norviit L. Steins AM. On the artificial kidney VII Acta Med Scand 1949; 132: $589 \cdot 602$.

29. Scribner BH, Caner JEZ, Buri R, Quinton W. The technique of continuous hemodialysis. j Am Soc Artif Int Organs 1960; 6: 88:103.

30. Ramirez O, Swartz C, Onesti G, Mailloux L, Brest AN. The winged in line shunt. Trans Amer Soc Artif Intern Organs 1966; 12: 220-221.

31. Fernando $\mathrm{ON}$. Arteriovenous fistulas by direct anastomosis. In: Vascular Access Surgery, Wilson SE ed. 2nd ed. Chicago: Yearbook Medical Publishers, 1988: 197-212.

32. Bonalumi D, Civalleri D, Rovida S, Adami GF, Gianetta E, Griffanti-Bartoli F. Nine years experience with end to end arteriovenous fistula at the "anatomical snuffbox" for maintenance haemodialysis. Br J Surg 1982; 69: 486-488.

33. Kinnaert $P$, Moris $C$. Arteriovenous fistula at the elbow for maintenance haemodialysis. In Access Surgery, Kootstra G, Jorning PJG eds. Lancaster: MTP Press, 1983: 25-29.

34. Gracz, KC, Ing TS, Soung LS, Armbruster KF, Seim SK, Merke! FK. Proximal forearm fistula for maintenance hemodialysis. Kidney Int 1977: 11: 71.75.

35. May J. Tiller D, Johnson J, Stewart J, Ross Sheil AG. Saphenous vein arterio-venous fistula in regular dialysis treatment. $\mathrm{N}$ Engl J Med 1969; 280: 770-771. 
36. Valenta J, Bilek J, Opatmry K. Autogenous saphenous vein graft as secondary vascular access for hemodialysis. Dial Transplant 1985; 14: 567.571 .

37. White GH, May J. Use of autogenous vein for fistulas and interpositional grafts. In: Vascular access surgery, Wilson ed., 2nd ed. Chicago: Year book Medical Publishers. 1988: $263 \cdot 272$.

38. Haimov M, Jacobson JH. Experience with modified bovine arterial heterografting peripheral vascular reconstruction and vascular access for hemodialysis. Ann Surg 1974; 180: 291.295.

39. Müller Wiefel H. Graft AV fistulas. In Progress in access surgery, Tordoir JHM, Kitslaar PJEHM, Kootstra G. eds. Maastricht: Datawyse, 1990: 14-17

40. Sabanayagam P, Schwartz AB, Soricelli RR, Chinitz JL, Lyons P. Experience with one hundred reinforced expanded PTFE grafts for angioaccess in hemodialysis. Trans Am Soc Artif Intern Organs 1980; 26: 582.583

41. Bonnaud Ph, Man NK. Ten years experience on 310 homologous vein grafts for arteriovenous fistula. In: Access Surgery, Kootstra G, Jorning PJG eds. Lancaster: MTP Press, 1983: 117.

42. Smits PJH, Slooff MJH, Lichtendahl DHE, Van Der Hem GK. The Biocarbon vascular access device (DiaTAB) for haemodialysis. Proc EDTA 1984; 21: 267.269.

43. Collins AV, Shapiro FL, Keshavia P, Ilstrup K, Andersen R, O'Brien T, Cosinto LC. Multicentre clinical experience with the Hemasite blood access device. In: Access Surgery Kootstra G, Joming PJG eds. Lancaster: MTP Press, 1983: 297.301

44. Turmel Rodrigues L, Pengloan J, Blanchier D, Abaza M, Birmelé B, Haillot O, Blanchard D. Insufficient dialysis shunts: Improved long term patency rates with close hemo dynamic monitoring, repeated percutaneous balloon angioplasty and stent placement. Radiology 1993; 187: 273-278.

45. Anderson CB, Gilula LA, Harter HR, Etheredge EE. Venous angiography and the surgical management of subcutaneous hemodialysis fistulas. Ann Surg 1977: 187: 194-204.

46. Berne TV, Turner A, Barbour BH. Angiographic evalution of Quinton-Scribner shum malfunction. Surgery 1971; 69: 588-594.

47. Boomsma JH, Beukhof JR, Geerlings W. Intravenous digital subtraction angiography of arteriovenous fistulas and shunts for hemodialysis. Diagn Imag Clin Med 1984; 22: $258 \cdot 261$.

48. Middleton WD, Picus DD, Marx MV, Melson GL. Color Doppler sonography of hemodialysis vascular access: Comparison with angiography. AJR 1989; 152: 633639.

49. Schwab, SI, Raymond JR, Saeed M, Newman GE, Dennis PA, Randal Bollinger R. Prevention of hemodialysis fistula thrombosis. Early detection of venous stenoses. Kidney Int 1989; 36: 707-711.

50. Zibari GB, Rohr MS, Landreneau MD, Brídges RM, Devault GA, Petty FH, Costley KJ. Brown ST, McDonald JC. Complications from permanent hemodialysis vascular access. Surgery 1988; 104: 681-686.

51. Ballard JL, Bunt TJ. Malone JM. Major complications of angioaccess surgery. Am J Surg 1992; 164: 229-232.

52. Davis GB, Dowd CF, Maroney TP, Lang EV, Halasz N. Thrombosed Dialysis Grafts: Efficacy of intrathrombic deposition of concentrated urokinase, clot maceration and angioplasty: AJR 1987; 149: 177-181.

53. Macdougall IC, Davies ME, Hallett I, Cochlin DL, Hutton RD, Coles GA, Williams JD. Coagulation studies and fistula blood flow during erythropoietin therapy in haemodialysis patients. Nephrol Dial Transplant 1991; 6: 862-867.

54. Tayior JE, McLaren M. Henderson IS, Belch JJF, Stewart WK. Prothrombotic effect of erythropoietin in dialysis patients. Nephrol Dial Transplant 1992; 7: 235.239.

55. Schulz V, Zehle J, Kindler J, Sieberth HG. Dipyridamol-Azetylsalizylsăure zur Prophylaxe von Shunt Thrombosen bei chronischen Dialysepatienten. Nieren-und Hochdruckkrankheiten 1981; 10: 49-52. 


\section{Chapter 1}

56. Glanz S, Gordon DH, Butt KMH, Hong J, Lipkowitz GS. The role of percutaneous angioplasty in the management of chronic hemodialysis fistulas. Ann Surg 1987; 206: 777.781.

57. Anderson CB, Jendrisak MJ. Complications of prosthetic arteriovenous fistulas. In: Progress in Access Surgery. Tordoir JHM, Kitslaar PJEHM, Kootstra G eds. Maastricht: Datawyse, 1990: $58-65$.

58. Vanholder $\mathrm{V}$, Hoenich $\mathrm{N}$, Ringoir $\mathrm{S}$. Morbidity and mortality of central venous catheter hemodialysis: A review of ten years experience. Nephron 1987; 47:274.279.

59. Erben J, Kvasnicka J, Bastecky J, Vortel V. Experience with routine use of subclavian vein cannulation in hemodialysis. Proc Eur Dial Transplant Assoc 1969; 6: 59-64.

60. Bambauer R, Jutzler GA. Transcutaneous insertion of the Shaldon catheter through the internal jugular vein as access for acute hemodialysis. Dial Transplant 1982; 11: 766-773.

61. Tapson JS. Temporary vascular access in British hemodialysis units. Artif Organs 1985; 9: $239 \cdot 242$.

62. Canaud B, Beraud J. Joyeux H, Mion C. Internal jugular vein cannulation using two silastic catheters. Nephron 1986; 43: 133-138.

63. Canand B, Cristol JP, Klouche K, Béraud J. Mion C. Silastic twin catheters: A flexible solution for temporary or long term vascular access problems in hemodialysis patients. In: Blood Purification in perspective. Man NK, Botella J, Zuchelli P. eds. Cleveland: ICAOT Press, 1992: 25.29.

64. Kluchert SA. Vena Axillaris obstructie [Dissertation], Leiden, 1982.

65. Clark DD, Albina JE, Chazan JA. Subclavian vein stenosis and thrombosis: a potential serious complication in chronic hemodialysis patients. Am J Kidney Dis 1990; 15: 265.268 .

66. Surratt RS, Picus D, Hicks ME, Darcy MD, Kleinhoffer M, Jendrisak M. The importance of preoperative evaluation of the subclavian vein in dialysis access planning. AJR 1991; 156: 623 625

67. Kahn D, Pontin AR, Jacobson JE, Matley P, Beningfield S, van Zijl-Smit R. Arteriovenous fistula in the presence of subclavian vein thrombosis: a serious complication. Brit J Surg 1990; 77: 682 .

68. Dotter CT, judkins MP. Transluminal treatment of arteriosclerotic obstruction. Circulation 1964: 30: 654-670.

69. Grüntzig A, Hopff H. Perkutane Rekanalisation chronische arterielle Verschlusse mit einem netien Dilatationskatheter. Modifikarion der Dotter Technik. Dtsch Med Wochenschr 1974; 99: 2502-2505.

70. Frankl WS. A comparison of coronary artery bypass surgery and percutaneous transluminal angioplasty in the treatment of coronary artery disease, part 2. Modern Concepts Cardiovasc Dis 1990; 59: 37-42.

71. Lawrence PF, Franklin JM, Mineau E. Balloon catheter dilatation in patients with failing arteriovenous fistulas. Surgery 1981; 89: 439-442.

72. Dapunt O, Feurstein M, Rendl KH, Prenner K. Transluminal angioplasty versus conventional operation in the treatment of haemodialysis fistula stenosis: Results from a 5 year study. Br J Surg 1987; 74: 1004-1005.

73. Burger H, Zijlstra J. Kluchen SA, Kootstra G. Long term results of routine application of percutaneous transluminal angioplasty as an adjuvant to access surgery. In: Progress in access surgery. Tordoir JHM, Kitslaar PJEHM, Kootstra G eds. Maastricht: Datawyse, 1990: $165-170$. 
CHAPTER 2

\section{A survey of haemodialysis in the Netherlands}

H. Burger, G. Kootstra\#, F. de Charro*, P.Leffers+

From the Departments of Surgery, Diakonessenhuis Refaja, Dordrecht and the University Hospital Maastricht, "the Renal Replacement Registry Netherlands Rotterdam and + the Department of Epidemiology, University of Limburg.

Nephrology Dialysis Transplantation 1991; 6: 5-10 


\section{ABSTRACT}

After nearly 30 years of access surgery for haemodialysis, a survey of vascular access in a large population seemed relevant in order to analyze the state of the art.

On January 1, 1988, 2195 patients in 52 centres in the Netherlands (population 14714 900) were on long term haemodialysis and 588 on continuous ambulant peritoneal dialysis (CAPD) for renal insufficiency.

A questionnaire was mailed out, to which there was $100 \%$ response. Of all the patients on Iong term haemodialysis, $70 \%$ had a Cimino fistula, $22 \%$ a graft fistula and $6 \%$ a more proximal arm fistula. The remaining $2 \%$ had a Scribner shunt. Of all the graft fistulas, the expanded polytetrafluoroethylene (PTFE) graft was the one most used (58\%), followed by the homologous vein graft (25\%), the autologous vein graft (13\%) and those made of other other materials (4\%).

Preference for acute access was recorded; catheterization of the subclavian vein was used almost exclusively in 17 centres, while in 24 centres it was chosen in more than $50 \%$ of the cases. The femoral vein was almost always the choice for acute access in 6 centres and it was selected in more than $50 \%$ of the cases in 17 centres. Another alternative, the Scribner shunt, was applied in selected cases in 22 of the 52 centres.

Percutaneous transluminal angioplasty (PTA), as a method for treating stenoses in vessels used for vascular access, was applied routinely in 5 centres and occasionally in 19 centres. 


\section{INTRODUCTION}

Nearly 30 years ago, more than 15 years after the first successful haemodialysis by Kolff in 1943, a useful vascular access was created by Quinton, Scribner and Dillard. Since then, the technique and the results of access surgery for haemodialysis have been the subject of extensive research.

Information about vascular access is needed in order to provide professionals in the field with basic data about the extent of the problem, to provide data for the planning of facilities and to facilitate comparison of the use of different procedures all over the world. Such data about the actual state of vascular access for long term haemodialysis in larger populations turn out to be scarce.

Porter et al. reported on vascular access among haemodialysis patients in an area with over 12 million inhabitants in Ohio, U.S.A. [1]. In 2562. patients, the following types of vascular access were found: autogenous arteriovenous (A.V) fistula (65\%), graft fistula (34\%) and external Scribner shunt (1\%).

In the Netherlands, the centres for haemodialysis and continuous ambulant peritoneal dialysis (CAPD) are regularly surveyed regarding many aspects of dialysis and transplantation by RENINE, the renal replacement registry of the Netherlands. However, until now, vascular access has not received much attention. Only two studies thus far have been carried out in the Netherlands. In its 1978 annual report, the European Dialysis and Transplantation Association (EDTA) [2] gave data about vascular access in 14 European countries and compared them with 1975 data. In 1985, a postal survey about the state of access surgery in the Netherlands was conducted (Tordoir) [3]; hovever, this has not been published.

To gain a more current insight into vascular access and changes in practice over time, a questionniare was distributed to all centres for renal replacement in the Netherlands.

\section{MATERIALS AND METHODS}

A questionnaire about vascular access on January 1, 1988 was mailed to all the centres for renal replacement therapy in the Netherlands. On that date the population of the Netherlands was 14714900 [4].

The data registered included the number of patients with various types of vascular access: A-V fistula (Cimino), A.V shunt (Scribner), primary access (i.e., radiocephalic A.V fistula or first choice $A \cdot V^{\prime}$ shuni) and 
secondary access (i.e., all access other than primary access), as well as the number with vascular grafts: autologous vein, homologous vein (Vascogref ${ }^{\ominus}=$ Varivas $^{\ominus}$, Dardik ${ }^{\ominus}$, heterologous vessel (bovine), artificial vessel (expanded polytetrafluoroethylene (PTFE)), A-V fistula in the elbow and some other special forms of access. Centres were asked if the single needle method (the method of puncturing the A-V fistula with only one needle instead of the usual two) was used incidentally or routinely. There were also questions about the percentage of cases of long term haemodialysis, in which subclavian vein catheter, femoral vein catheter, A.V shunt (Scribner) or other access methods were used. Another topic was the frequency of application of percutaneous transluminal angioplasty (PTA): routinely, incidentally, or not at all. Finally, there were questions about whether the operating team included one surgeon, some surgeons, all surgeons, or surgical residents.

Permission was requested to allow RENINE to provide information about the age and sex distribution of patients per centre, the number of patients on CAPD, the number of patients who were previously transplanted but who were now back on dialysis and about the number of patients with diabetes mellitus.

\section{RESULTS}

All of the questionnaires were filled out and returned. It was found that as of January 1, 1988, 2807 patients (1503 men and 1304 women) were on renal replacement therapy in 52 centres. Of these, 2195 (78\%) were on long term haemodialysis. Another 588 patients (20\%) were on CAPD, while for 24 the type of treatment was unknown.

The 52 centres included 12 academic dialysis units, 35 dialysis units in general hospita!s and 5 other units.

Two centres were foi home dialysis only, three centres for hotel dialysis only, three centres for children and one centre for CAPD only. A fourth centre for children was incorporated into the dialysis centre of a university hospital.

There was a wide range in the number of patients in the different centres (3.115, mean 42). There were 13 centres with more than 70 patients and 9 with less than 30 patients.

A total of 2170 patients were found to have a vascular access. The different types of shunts are listed in Table 1. Some 1517 (70\%) of the patients had a radiocephalic (Cimino) A.V fistula, $474(22 \%)$ a graft A.V fistula and $139(6 \%)$ an elbow A.V fistula. Thirty-eight (2\%) A.V (Scribner) shunts were counted and two Biocarbon ${ }^{\circ}$ access devices. Among the 
graft A.V fistulas with their respective percentage of grafts were: PTFE (58\%), autologous vein (13\%), homologous vein Varivas ${ }^{8}$ (25\%) or Dardik $^{\ominus}(1 \%)$ and heterologous vein bovine (3\%) (Table 2).

Table 1. Distribution of types of access among all patients with a vascular access Distribution of centres according to prevalence of the specific type of vascular access per centre.

Number of patients Proportion of patients per centre with specified type of access

\begin{tabular}{lllll}
\hline $0-19 \%$ & $20-39 \%$ & $40-59 \%$ & $60-79 \%$ & $80-100 \%$
\end{tabular}

A V fistula

(Cimino)

1517

$(70 \%) \quad 1$

3

8

26

13

A.V fistula

(graft)

474

( $22 \%) \quad 28$

18

4

2

0

A. $V$ fistula

(elbow)

$139 \quad(6 \%) \quad 49$

30

3

0

A. $V$ shunt

(Scribner)

38

( $2 \%) \quad 52$

$0 \quad 0$

$0 \quad 0$

Other shunt

Biocarbon

$$
2 \quad(0.1 \%) \quad 52
$$

$0 \quad 0$

0

)

All types vascu-

lar access $\quad 2170 \quad(100 \%)$

Table 2. Graft fistulae, their distrihution and the centres where certain types of access were present.

\begin{tabular}{|c|c|c|c|c|}
\hline & $\begin{array}{l}\text { Number of } \\
\text { patients }\end{array}$ & $\begin{array}{l}\text { Proportion of all } \\
\text { types of access }\end{array}$ & $\begin{array}{l}\text { Proportion of } \\
\text { grafts }\end{array}$ & $\begin{array}{l}\text { Number of } \\
\text { centres where } \\
\text { graft is used }\end{array}$ \\
\hline All grafts & 474 & $22 \%$ & $100 \%$ & 47 \\
\hline PTFE: & 274 & $13 \%$ & $58 \%$ & 35 \\
\hline Auttologous vein & 63 & $3 \%$ & $13 \%$ & 22 \\
\hline Homologous vein & 119 & $6 \%$ & $25 \%$ & 20 \\
\hline Bovine graft & 13 & $0.6 \%$ & $3 \%$ & 7 \\
\hline Dardik graft & 5 & $0.2 \%$ & $1 \%$ & 2 \\
\hline $\begin{array}{l}\text { Other types of } \\
\text { vascular access }\end{array}$ & 1696 & $78 \%$ & & \\
\hline $\begin{array}{l}\text { All types of vascu. } \\
\text { lar access }\end{array}$ & 2170 & $100 \%$ & & \\
\hline
\end{tabular}


The four centres for children, which are all academic, treated a total of 62 patients. They apply an age limit of approximately 16 years (mean age 10 years). Some young children were also treated in centres that are not specifically paediatric. There was a high percentage of A.V fistulae: $86 \%$. CAPD was the dialysis method in $43 \%$ of the children.

The percentage of diabetic patients among the whole dialysis population was $7 \%$. The percentage of diabetic patients in the different centres varied widely. Diabetes mellitus was found in a frequency of more than $10 \%$ in 13 centres. No correllation was found between a high frequency of diabetes and a certain pattern of vascular access, e.g. more secondary access.

The use of the single needle technique was the first choice in four centres (75\%-100\% of the patients on single needle technique), while five others $(25 \%-74 \%)$ used it as a good alternative. The majority used it only when the two needle technique failed or not at all (Table 3 ).

Table 3. Single needle technique as routine for access to A.V fistulae in the different centres. Number of patients on single-neecile access and percentage of all patients in haemodialysis.

\begin{tabular}{lcc}
\hline & Number of centres & $\begin{array}{l}\text { Number of patients in these centres } \\
\text { (percentage of all patients) }\end{array}$ \\
\hline $\begin{array}{l}\text { Single needle } \\
95.100 \% \text { routine }\end{array}$ & $85 \quad(4 \%)$ \\
$\begin{array}{l}\text { Single needle } \\
50.94 \% \text { routine }\end{array}$ & $76 \quad(3.5 \%)$ \\
$\begin{array}{l}\text { Single-needle } \\
25.49 \% \text { routine }\end{array}$ & $47 \quad(296)$ \\
$\begin{array}{l}\text { Single needle } \\
1.24 \% \text { routine }\end{array}$ & $46 \quad 3.5 \%)$ \\
Single needle never & 19 & 0 \\
Total & 52 & $284(13 \%)$ \\
\hline
\end{tabular}

PTA was used routinely in 5 centres, occasionally in 19 centres and never in 28 centres.

Access surgery was done mainly by one surgeon (more than $80 \%$ of the operations) in 13 centres, by a group of surgeons in most centres, but rarely by residents. Differences in access were not found in relation to the number of surgeons employed in access surgery. 
Acute access methods in long term haemodialysis were analysed. Catheterization of the subclavian vein was the first choice in 17 centres. Twenty-four centres used the subclavian vein in more than $50 \%$ of the cases. The femoral vein was used nearly exclusively in 6 centres and in more than $50 \%$ of the cases in 17 centres. The Scribner shunt, as an alternative acute access, was in use in 22 centres and in more than $5 \%$ of the cases in 11 centres. Jugular vein catheterization was only practiced in two centres.

The number of patients with failed transplants ( 572 patients) varied very much per centre, from $0 \%$ to $75 \%$ (on the average 11 patients per centre). In 11 centres more than $30 \%$ of the patients had transplants that failed ( 220 patients). These included 9 of the 12 academic centres, which, in turn, included the centres for children only.

Correlations between types of vascular access and characteristics of the centres were explored. Mean age, percentage of patients 65 years and older, predominance of men or women, percentage of patients with diabetes mellitus, percentage of patients on CAPD, percentage of patients with failed transplants and number of surgeons occupied with vascular access did not correlate with any special type of vascular access or percentage of primary or secondary access.

\section{DISCUSSION}

The different types of access call for a close examination.

\section{The Cimino-Brescia A-V fistula and its variations}

There is a consensus in the literature that the A.V fistula in the forearm, the radiocephalic fistula, offers the best vascular access when, in fact, it is possible to create such a fistula or a variation of it [5]. Maintaining this sort of access in $61 \%-80 \%$ of the patients is apparently not possible or desirable in 12 centres. On the other hand, in 14 centres, $81 \%$ or more of the patients have a Cimino A V fistula (Table 1). Factors such as intensity of treatment and diagnostics before the stage of terminal renal insufficiency was reached, damaging veins and arteries and, on the other hand, an active policy of sparing vessels, play a role.

\section{The Scribner A-V sbunt}

The first serviceable vascular access is still in use but in a decreasing number of centres [6]. Only 38 Scribner shunts were registered, the shunt being largely replaced for acute access by semipermanent catheters. In two centres more than 5 shunts, meant as a primary access (first 
choice) or secondary access (second choice) were counted. In five centres more than $5 \%$ of the patients receiving haemodialysis ( $6 \%-15 \%)$ had an A-V shunt. There may still be a valid place for the Scribner shunt as a safe and easy access as it has few serious complications when constructed with great care and maintained with the help of percutaneous transluminal angioplasty $[7,8]$.

\section{Primary and secondary access}

In the present survey, primary access was defined as an A.V fistula (Cimino) or a first choice A.V shunt (Scribner). We presume that whenever possible a Scribner shunt is replaced by a Cimino fistula, the latter being the best access available.

There was a wide variation (100\%-38\%) in the percentage of patients with a primary access (Cimino fistula or Scribner shunt as first choice) in the different centres. In some patient populations the state of the vessels may be better than in others, something which makes comparison difficult. On the other hand, some centres seem to prefer a certain form of secondary access (e.g., a homologous venous graft fistula). Many centres strongly prefer an A-V fistula and will spend a good deal of energy trying to create and preserve one. Others choose a graft fistula as a very acceptable alternative for many of their patients.

\section{Vascular grafts}

When a piimary access is not possible, several choices aie available. The most popular option among vascular surgeons nowadays seems to be an artificial graft, the PTFE graft (Goretex ${ }^{\circledR}$ or Impra ${ }^{\circledR}$ ). The autologous vein graft has been tried extensively and is still in use. The homologous vein (Varivas ${ }^{\circledR}$, formerly called Vascogref(), a prepared human vein, is now being used increasingly (Table 2). Several other grafts have been used extensively (bovine, Dardik ${ }^{\oplus}$ ) but do not appear to have proved to be satisfactory in most hands. The same is true for implants like the Biocarbon ${ }^{\circledR}$ and Hemasite devices.

\section{The centres for children}

Dialysis in children's centres has different characteristics, especially with regard to the frequent application of CAPD in young children [10]. The pattern of vascular access is also distinctive, with a high percentage of A. $\mathrm{V}$ fistulae. 


\section{Cbanges in vascular access patterns}

The 1985 questionnaire [3] had a $74 \%$ response rate ( 37 of the then 50 centres), which represented $80 \%$ of all patients on renal replacement therapy.

During the last 10 years, the percentage of patients with an A.V fistula of the forearm (Cimino), generally accepted as the first choice for vascular access, has not changed substantially (Table 4). However, there has been a significant change in the frequency of other types of access. The Scribner shunt is used much less. Among the grafts, the use of PTFE and the homologous vein (Varivas ${ }^{*}$ ) is steadily increasing and the use of the autologous vein is decreasing (Fig.1).

\section{Diabetes mellitus}

There is no simple explanation for the fact that only $7 \%$ of the patients on dialysis had diabetes mellitus. The prevalence of diabetes mellitus in the population of the Netherlands is estimated at $2.3 \%$ ( $0.3 \%$ type I and 2\% type II). This is not much different from the overall situation in the US (prevalence estimated at 2.6\%), although there are considerable variations between the different states. The prevalence of diabetes mellitus in Europe varies greatly. In the Nordic countries there is a large population of young type I diabetes mellitus, while in the south there is a preponderance of elderly type II patients. Acceptance policies for elderly diabetics may differ.

\section{Perculaneous transluminal angioplasty}

Results of PTA of vascular access were not asked for in the questionnaire. In a recent study [8] an immediate success rate of $90 \%$ of PTA was recorded. An extended longevity for Scribner shunts of 9 weeks and for A-V fistulae of 10 months for each PTA was computed, early failures not excluded [8].

The varying patterns of vascular access in the different centres seem to be influenced primarily by the choice of the vascular surgeon, the nephrologist and the nursing staff of the dialysis centres. None of the recorded characteristics of the centres correlated with a particular type of vascular access.

The quality of vascular access should have a high priority in the care of patients who need haemodialysis. In the Netherlands a working group for access surgery was established in 1989 to advance that specialty.

This survey of vascular access among more than 2000 patients, reflects the choices presently available to surgeons who seek to establish and 


\section{Chapter 2}
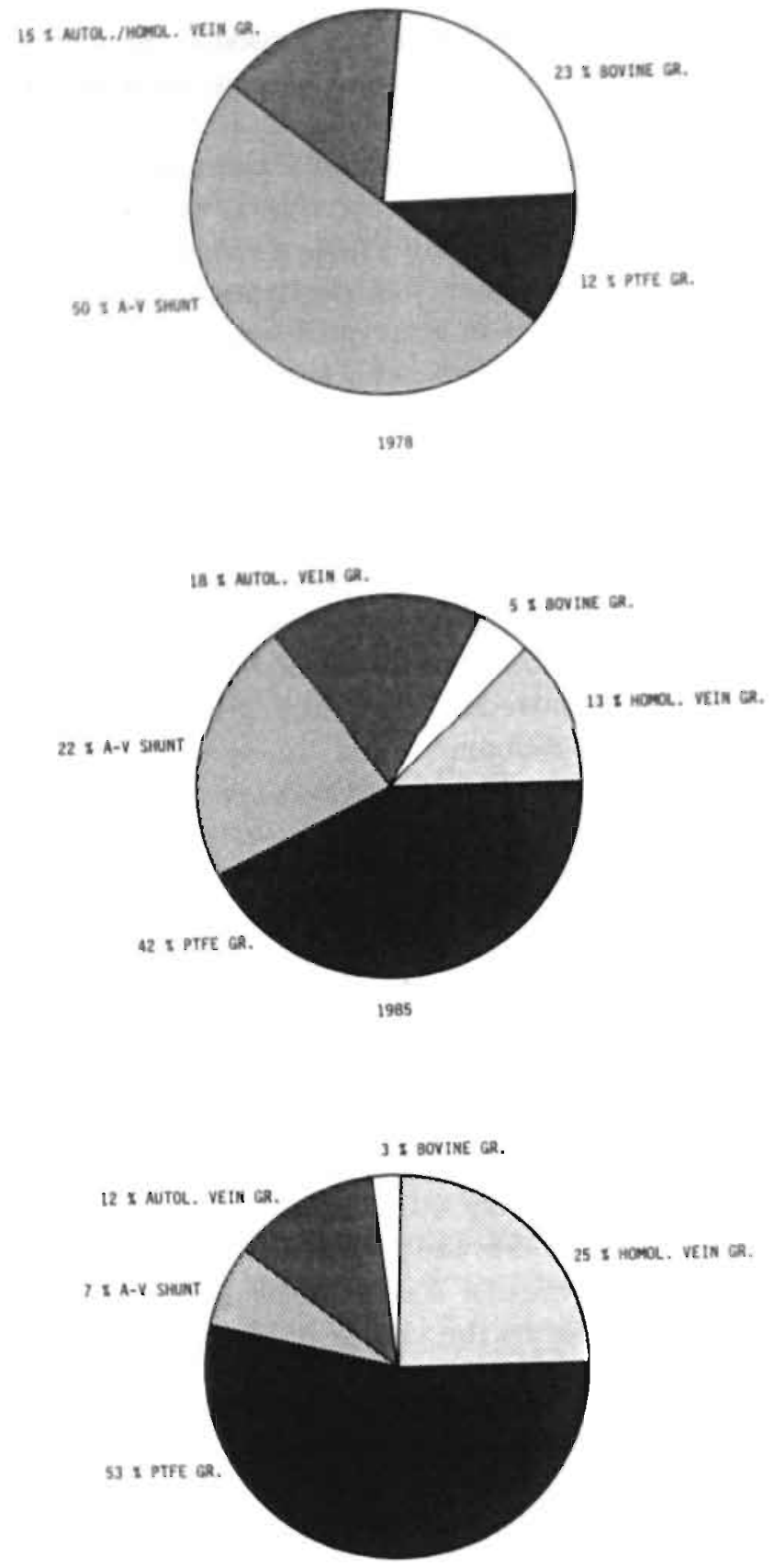

1989

Figure 1 . Distribution of types of vascular access, excluding the autogenous A.V fistula, in 1978, 1985 and 1988. 
maintain the lifeline for patients on haemodialysis. Research in controled, multicentre studies (e.g., comparing the results of the autologous vein graft, the homologous vein graft and the PTFE graft) may lead to more consensus about secondary vascular access.

\section{Acknowledgements}

We are indebted to RENINE and to the many nephrologists, surgeons and other staff members for their cooperation in providing the authors with the necessary data. We also thank dr. J.H.M. Tordoir for generously placing the data from the 1985 access survey at our disposal.

\section{REFERENCES}

1. Porter JA, Sharp WV, Walsh EJ. Complications of vascular access in a dialysis population. Current Surgery 1985; 42: 298:300.

2. Pocket Yearbook 1988. Netherlands Central Bureau of Statistics. The Hague: Staats uitgeverij 1988

3. Tordoir J. A survey of vascular access in the Netherlands in 1985. Personal com munication.

4. EDTA (European Dialysis and Transplantation Association) Report. 1978, 53-56.

5. Haimov $M$. The peripheral subcutaneous arteriovenous fistula. In: Haimov $M$, ed. Vascular Access, New York: Futura Publishing Company 1987; 41-58.

6. Singer $\mathbf{A}$. The external arteriovenous silastic cannula shum. In: Haimov $\mathbf{M}$, ed. Vascular Access. New York: Futura Publishing Company 1987: 25.39.

7. Zijlstra J, Scholten AP, Kluchert SA, Burger H. First results of percutaneous transluminal angioplasty of Scribner shunts and Cimino-fistulas. Journal of Medical Imaging 1987; 1: 155,159 .

8. Burger H, Zijlstra IJ. Kluchen SA, Scholten AP. Kootstra G. Improvement of longevity of vascular access by percutaneous transluminal angioplasty. Nephrol Dial Transpl 1990; 5: 608.611.

9. Broyer M, Brunner FP, Brynger $H$, Fassbinder W, Guillou PJ, Oules R: EDTA Registry Centre Survey, 1985. Nephrol Dial Transplant 1987; 2: 475-487.

10. Monnens LAH, Donckerwolcke RAMG. Ploos van Amstel SLB, Ten Velden GHM, WolfI ED. Children with terminal renal failure in the Netherlands 1979-1986. Ned Tijdschi Geneeskd 1989; 133: 1364-1366. 
CHAPTER 3

\section{Percutaneous Transluminal Angioplasty \\ Improves Longevity of Arteriovenous Shunts and Fistulas for Haemodialysis}

H. Burger, J.J. Zijlstra*, S.A. Kluchert\#, A.P. Scholten\# and G. Kootstra+

From the Departments of Surgery, "Radiology and \#Nephrology, Diakonessenhuis Refaja, Dordrecht and the +Department of Surgery of the University Hospital, Maastricht, the Netherlands.

Nephrology Dialysis Transplantation 1990; 5: 608-611. 


\begin{abstract}
Percutaneous transluminal angioplasty (PTA) has proved to be an effective method for dilating stenoses in veins and arteries used for vascular access in haemodialysis. Not only can stenoses of arteriovenous fistulas (Cimino and other types) be treated, but stenoses of arteriovenous shunts (Scribner) can also be successfully dilated.

Over a period of 3 years, PTA was applied 94 times in a haemodialysis population of about 50 patients. It reduced the number of surgical interventions required to maintain permanent vascular access by $30 \%$. The longevity of external and internal shunts was increased by nearly 2 months and 1 year, respectively, with a PTA. Repeated PTA's were often possible.

During the 3 years that PTA was practiced routinely, there was a $50 \%$ reduction in the number of operations with stenosis as indication as compared to the 3 preceding years.
\end{abstract}




\section{INTRODUCTION}

Percutaneous transluminal angioplasty (PTA), developed by Dotter in 1964 [1], was introduced in the early 1980's for dilatation of stenoses occurring after the development of arteriovenous (A-V) fistulas. Most authors report satisfying results [2-9], although one observed an increase in costs and a shorter patency [10]. Extensive experience has been gathered concerning the dilatation of stenoses caused by degenerative lesions in the coronary and peripheral arteries. It has also been established that good results can be obtained when PTA is used for vascular access. The fibrous stenoses that most often result from repeated punctures and changed bloodstream characteristics can be dilated successfully.

While initially only stenoses of A.V fistulas were treated, it later became evident that the well-known stenoses at the end of an implanted vessel tip of an external A.V shunt (i.e., the Scribner shunt) could also be treated with PTA. The Scribner shunt plays a reduced role in vascular access. It comprises now only $2 \%$ of all forms of access in the Netherlands [13]. It still has a place in selected patients and as an acute access or a semipermanent secondary access. The technique of using PTA for the Scribner shunt was developed by Zijlstra et al. [11, 12]. They employed modified catheters for internal and external shunts, which are now commercially available (Schneider Europe AG Zurich, Switzerland). The Ramirez variation of the Scribner shunt, which has a straight subcutaneous tubing and an optional external bend, is recommended for easier catheterization. Stenosis may recur after a dilatation, but dilatations can be repeated successfully. $[9,11,12]$

Although Brooks et al. [10] report an increase in costs, we have calculated that the cost of a PTA on an out-patient basis is considerably lower than the costs of an operation plus an average of several days in the hospital [12]. Of course some surgical interventions may take only one or two days in hospital, but others require an extended hospitalization. A PTA has to be repeated more often than a treatment of stenosis by surgical means, but on a yearly basis the cost of a PTA is still lower.

\section{PATIENTS AND METHODS}

From January 1983 until January 1989, an average of 50 patients were treated with chronic haemodialysis in the Department of Nephrology of the Refaja Hospital in Dordrecht, The Netherlands. Characteristics of the group of patients were the followving: Mean number of patients 49 
(range 46.54), mean age 51 years (range 48-56), mean duration of haemodialysis 5.1 years (range 4.7-5.4).

During the study period, most of the operations and PTA's were carried out by the same surgeon (HB) and radiologist (JJZ).

The effect of PTA on the number of interventions for stenosis of the artery or vein involved in the access was analyzed by counting all the interventions before and after the application of PTA. Except for the first access operation, all operations were counted as reinterventions. In order to gain a fair insight into the effect of PTA, the assumption was made that any malfunctioning of a vascular access could be related to a stenosis.

Since March 1986, PTA has been used more and more often in the Refaja Hospital and since $1987 \mathrm{it}$ has been the treatment of choice for all stenoses. Rising venous pressure or diminished arterial pressure during haemodialysis requires angiography and when a potentially dilatable stenosis is found, a PTA is done. As mentioned earlier, the technique of using PTA has already been described elsewhere $[11,12]$, but will also be summarised here.

For dilatation of a Cimino fistula, a 5 French catheter, $50 \mathrm{~cm}$ in length, with a balloon length of $4 \mathrm{~cm}$ and diameter, when inflated, of 6 or $8 \mathrm{~mm}$, is used (Fig.1). A straight wire with a floppy tip is used. The

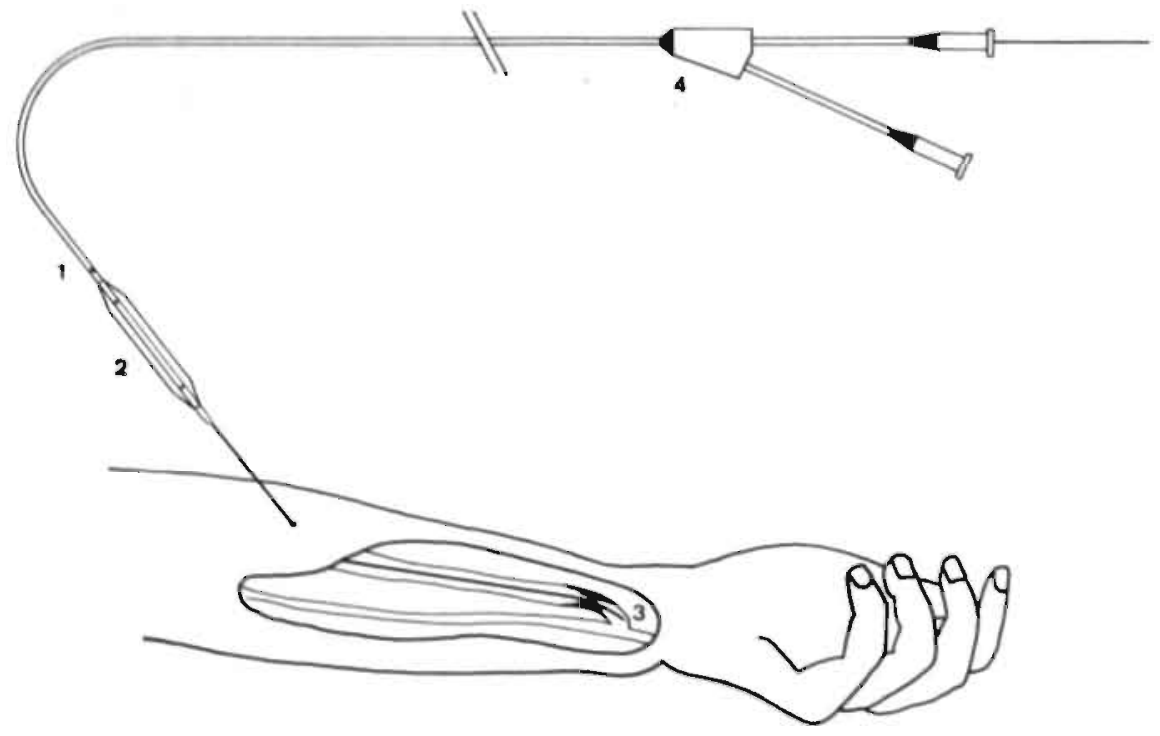

Fig 1. Cimino A.V fistula. (1) Side bole to flusb botb sides of the stenosis during the procedure. (2) Low profile balloon of $6.8 \mathrm{~mm}$. (3) Most common site of stenosis in Cimino fistulas (4) 5 Frencb catbeter, $50 \mathrm{~cm}$ in length. 
wire is $100 \mathrm{~cm}$ in length and has a diameter of $0.020 \mathrm{in}$. The balloon catheter is inserted cranially to the anastomosis of the Cimino fistula through a puncture of the venous limb using the Seldinger technique. The veins have thick walls and may be difficult to enter. They often require prolonged compression in order to achieve hemostasis after the procedure.

For dilatation of a Scribner shunt, a 4.3 French catheter with a balloon length of $2 \mathrm{~cm}$ and diameter, when inflated, of 3.7 or $4.3 \mathrm{~mm}$ is used. The diameter of the concomitant guide wire with a short floppy tip is $0.012 \mathrm{in}$. The way in which the Scribner balloon catheter is introduced is shown in Fig.2. The Teflon silastic tube of a Scribner shunt is curved. The resistance inside this curve can be diminished by lubricating the tube with radiodiagnostic contrast media. The diameter of the connection between blood vessels and silastic tube the vessel tip is the real limiting factor for catheter introduction. A 4.3 French catheter with a $3.7 \mathrm{~mm}$ balloon can be introduced even when the diameter of the connection is $1.6 \mathrm{~mm}$.

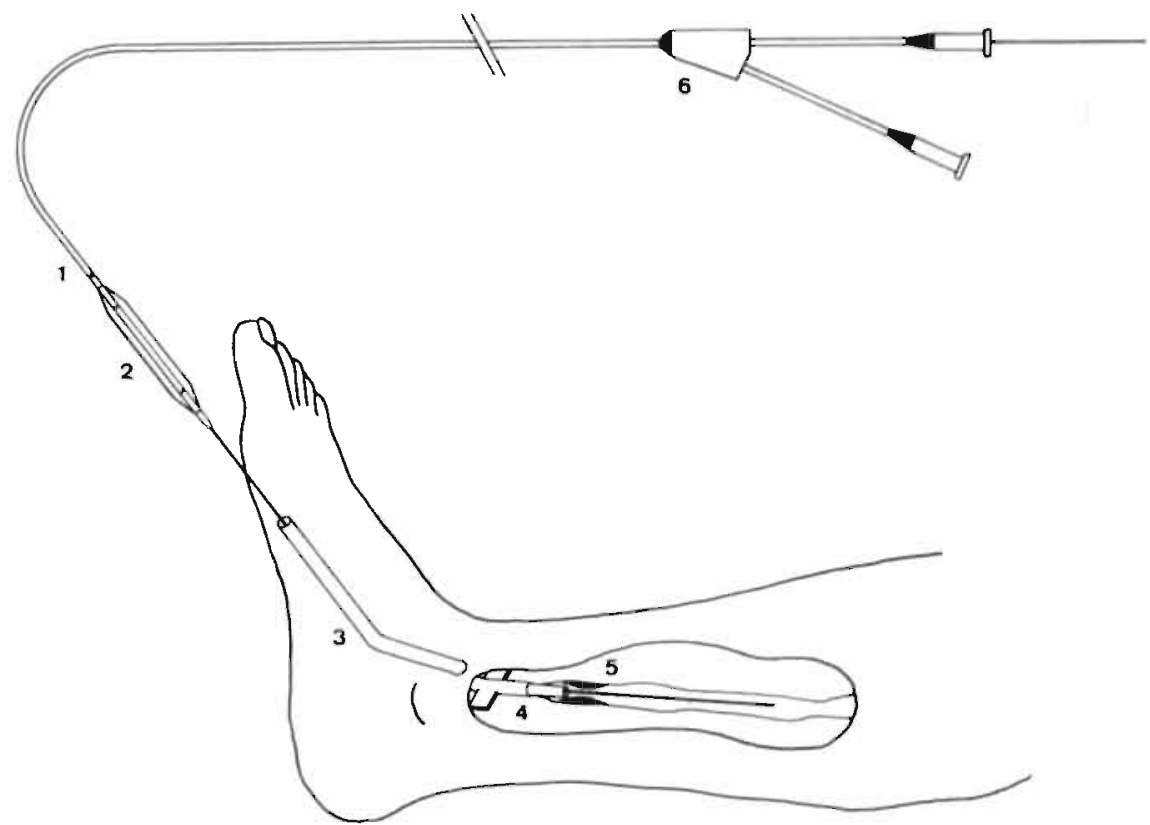

Fig.2. Scribner A.V shunt. (1) Side bole io flusb botb sides of the stenosis. (2) Super low profile balloon, circumference $3.7 .4 .2 \mathrm{~mm}$. (3) Venous limb of a Quinton-Scribner shunt, variant according to Ramirez. (4) Teflon vessel tip, circumference $1.6 .2 .8 \mathrm{~mm}$. (5) Most common site of stenotic area in Scribner sbunts. (6) 4.3 Frencb catbeter, tength $50 \mathrm{~cm}$. 


\section{Chapter 3}

In both procedures, the super low-profile balloon catheters (Schneider Europe AG, Switzerland) are flushed with a heparin solution during dilatation by withdrawing the feeder from the short catheter. A special feature of the catheters used in both procedures are the side holes just a few millimeters proximal to the balloon. During balloon inflation, both sides of the fistula or shunt can be flushed simultaneously, thus preventing clotting during occlusion.

Occlusion time can be as long as $30 \mathrm{~min}$. The procedure is terminated when no deformity of the balloon can be visualised. Inflation times of up to $30 \mathrm{~min}$ are often necessary.

In the present study, PTA was considered a success when the stenosis was dilated and the procedure resulted in a functioning shunt with decreased venous pressure or increased arterial pressure. An early failure implied the opposite. Thus, the number of failures was kept to a minimum. The early failures (i.e., those occurring within 4 days) are included in the results.

\section{RESULTS}

Over the course of the study period, a reduction in the number of surgical interventions and an increase in the number of PTA's was observed. Surgical interventions for stenosis decreased by $50 \%$. This decrease was more manifest with external shunts than with internal shunts, as illustrated in Table 1. There was an overall $30 \%$ decrease in the number of surgical interventions needed to maintain vascular access.

During the study period, the number of shunts fluctuated. In order to achieve a better understanding of the effects of PTA, the ratio between the number of shunts and the number of interventions with the indication of stenosis was calculated.

The number of PTA's and surgical interventions are illustrated in Tables 1 and 2. A success rate of $90 \%$ was atained in the first 95 PTA's.

The mean longevity after a PTA (inciuding the $10 \%$ that failed) was 310 days for an arteriovenous fistula and 54 days for an external shunt. When correcting for early failures (those in the first 4 days), the mean longevity was 347 days for an arteriovenous fistula and 59 days for an external shunt.

There were five complications with the PTA technique. In 95 PTA's, leakage of contrast from a ruptured vein was seen three times, but only the first time an operation was performed. Conservative treatment (i.e., light compression) later on sufficed. In one case, the tip of a Scribner shunt had to be surgically attached after a dilatation and in another 
Table 1. Surgical reinterventions for internal and external shunts and PTA from 1983 to 1988

\begin{tabular}{|c|c|c|c|c|c|c|}
\hline Year & 1983 & 1984 & 1985 & 1986 & 1987 & 1988 \\
\hline Total number of patients & 46 & 49 & 47 & 45 & 54 & 53 \\
\hline \multicolumn{7}{|l|}{ All internal shunts (all types } \\
\hline A.V fistulae) & 32 & 31 & 32 & 33 & 45 & 46 \\
\hline \multicolumn{7}{|l|}{ External shunts (Scribner- } \\
\hline Ramirez shunts) & 13 & 16 & 14 & 10 & 8 & 6 \\
\hline Biocarbon shunt & 1 & 1 & 1 & 1 & 1 & 1 \\
\hline $\begin{array}{l}\text { Reinterventions stenosis internal } \\
\text { shunts }\end{array}$ & 14 & 20 & 13 & 10 & 10 & 14 \\
\hline $\begin{array}{l}\text { Reinterventions stenosis external } \\
\text { shunts }\end{array}$ & 26 & 24 & 16 & 11 & 6 & 2 \\
\hline Reinterventions other indications & 3 & 4 & 10 & 3 & 12 & 11 \\
\hline All interventions & 43 & 48 & 39 & 24 & 28 & 31 \\
\hline PTA stenosis internal shunts & - & - & 1 & 5 & 13 & 20 \\
\hline PTA stenosis external shunts & - & - & - & 13 & 20 & 23 \\
\hline All PTA & & & & 18 & 33 & 43 \\
\hline
\end{tabular}

Table 2. The ratio between the number of surgical reinterventions neede to maintain vascular access and the number of arteriovenous shunts of a certain type from 1983 to 1988

\begin{tabular}{|c|c|c|c|c|c|c|}
\hline Year & 1983 & 1984 & 1985 & 1986 & 1987 & 1988 \\
\hline $\begin{array}{l}\text { Total number of patients as } \\
\text { of June } 30 \text { th }\end{array}$ & 46 & 49 & 47 & 45 & 54 & 53 \\
\hline Ratio all interventions/all shunts & 0.93 & 0.98 & 0.83 & 0.53 & 0.52 & 0.57 \\
\hline $\begin{array}{l}\text { Ratio reinterv. stenosis int. } \\
\text { shunts/int. shurnts }\end{array}$ & 0.44 & 0.64 & 0.40 & 0.30 & 0.22 & 0.30 \\
\hline $\begin{array}{l}\text { Ratio reinterv. stenosis ext. } \\
\text { shunts/ext. shunts }\end{array}$ & 2.00 & 1.50 & 1.42 & 1.10 & 0.75 & 0.33 \\
\hline $\begin{array}{l}\text { Ratio all reinterv. stenosis/all } \\
\text { shunts }\end{array}$ & 0.87 & 0.90 & 0.62 & 0.47 & 0.30 & 0.30 \\
\hline
\end{tabular}


case desobstruction was needed after dilatation of an anastomosis of a Biocarbon shunt followed by thrombosis.

\section{DISCUSSION}

Our group of patients was no different from a standard haemodialysis centre population [13]. During the 6 years of the study, the number of A.V fistulas increased, while the number of external shunts (Scribner) decreased, a trend which is apparent elsewhere [14]. We want to stress that a maximum effort to make the best possible A.V fistula or shunt at the start is the basis for a good access.

In the literature and also in our series, the arteriovenous fistulas need relatively few reinterventions, but with the application of PTA, the reintervention ratio for fistulas decreased even more. It is unlikely that the results were biased by interperson variation or change in policy. During the 6-year study period, $90 \%$ of all access surgery was done by one and the same surgeon and the indication to create a certain type of vascular access was established by two experienced nephrologists, together with this surgeon. It therefore seems reasonable to attribute the better results to the use of PTA.

The use of PTA has had a significant impact on the number of surgical interventions indicated for treatment of vascular stenosis in access surgery. PTA promises to be a real innovation in the management of vascular access and it positively affects the quality of life for the patient. An intervention on an out patient basis or during a short hospital stay is appreciated by patients much more than surgery, which comes at a higher cost. Surgical reinterventions can be performed without the need of hospital admission sometimes, but more extended surgery and the whole surgical procedure often require a stay in the hospital.

The fact that the access is available the next day, which after surgery cannot always be the case, is an improvement in the quality of haemodialysis. Elaborate procedures, such as temporary haemodialysis by catheters, can be avoided.

Surgical intervention for stenosis in a vein or artery of an A.V fistula usually means a venous or expanded polytetrafluoroethylene (P.T.F.E) patch, a transluminal angioplasty, or eventually a bypass procedure. In an external shunt, the vessel tip has to be reimplanted more proximally, which means loss of a venous or an arterial access site. All these disadvantages can be avoided using PTA.

PTA increases the longevity of an internal shunt by 310 days ( 347 days excluding early failure). In the present study, an external shunt 
had an increased longevity of 54 days ( 59 days excluding early failure).

Complications of PTA, such as thrombosis or the rupture of a blood vessel, do occur but can be managed without serious problems as they are usually diagnosed immediately by angiography $[6,12]$. The latter can often be treated conservatively. Three times we operated for a complication. Slight leakage is not an indication for operation anymore.

In a recent survey of access surgery in all centres in The Netherlands [13], it was found that PTA was never carried out in 28 centres, occasionally carried out in 19 centres and regularly carried out in only 5 centres.

The application of PTA means a very substantial reduction in both cost and the use of vessels for access. Moreover, it improves the quality of life of patients dependent upon haemodialysis.

\section{Acknowledgements}

We wish to thank P. Leffers for his epidemiological advice and E.P. Beenen for the illustrations.

\section{REFERENCES}

1. Dotter CT, Judkins MP. Transluminal treatment of arteriosclerotic obstruction: Des. cription of a new technique and a preliminary report of its application. Circulation 1964: 30: 654.670.

2. Lawrence PF, Miller FJ and Mineau DE. Balloon catheter dilatation in patients with failing arteriovenous fistulas. Surgery 1981; 89:439-442.

3. Gordon DH, Glanz S, Butt KM, Adamsons RJ, Koenig MA. Treatment of stenotic lesions in dialysis access fistulas and shunts by transluminal angioplasty. Radiology 1982; 143: $53-58$.

4. Gaux JC, Bourquelot P, Guidet B, Seurot M, Raynaud A, Blanchard D. Short-term follow -up of percutaneous transluminal angioplasty of stenoses located on fistulas used for haemodialysis. In: Kootstra G. Jorning PJG eds. Access Surgery, Lancaster: M.T.P. Press, 1983: 223.

5. Saeed M, Newman GA. Mc Cann RL, Sussman SK, Braun SD. Sienoses in dialysis fistulas: Treatment with percutaneous angioplasty. Radiology 1987; 164: 693-697.

6. Glanz S, Gordon DH, Butt KMH, Hong J, Lipkowiz GS. The role of percutaneous angioplasty in the management of chronic hemodiaiysis fistulas. Ann Surg 1987; 206: 77.81 .

7. Dapunt $\mathrm{O}$, Feurstein $\mathrm{M}$, Rendl $\mathrm{KH}$, Prenner $\mathrm{K}$. Transluminal angioplasty versus conventional operation in the treatment of haemodialysis fistula stenosis: results from a 5-year study. Br J Surg 1987; 74: 1004-1005.

8. Cada E, Karnel F, Mayer G, Langle F, Scurawitzki H, Graf H. Percutaneous transluminal angioplasty of failing arteriovenous dialysis fistulae. Nephrol Dial Transplant 1989; 4: 57.61 .

9. Gmelin E, Winterhoff $\mathrm{R}$, Rinast $\mathrm{E}$. Insufficient haemodialysis access fistulas: late results of treatment with percutaneous balloon angioplasty. Radiology 1989; 171: 657.660.

10. Brooks JL, Sigley RD. May KJ, Mack RM. Transluminal angioplasty versus surgical repair for stenosis of hemodialysis grafts. Am J Surg 1987; 153:530-531. 
11. Zijlstra J, Scholten AP, Kluchert SA, Burger H. First results of percutaneous transluminal angioplasty of Scribner shunts and Cimino fistulas. Journal of Medical Imaging 1987; 1: $155-159$.

12. Zijlstra J. Percutaneous transluminal angioplasty in vascular access for hemodialysis. A manual for the radiologist [Dissertation], Utrecht, 1989: 95-96.

13. Burger $\mathrm{H}$, de Charro $\mathrm{F}$, Kootstra G. A survey of vascular access in the Netherlands. Nephrol Dial Transplant 1991; 6: 5-10.

14. Haimov $M$. The subcutaneous arteriovenous fistula. In:Haimov $\mathrm{H}$, ed. Vascular access. New York: Futura Publishing Company 1987: 41-58. 
CHAPTER 4

\title{
Survival of vascular access for haemodialysis
}

\author{
H. Burger, S.A. Kluchert", G. Kootstra\#, \\ P.J.E.H.M. Kitslaar\#, D.Th. Ubbink\#.
}

From the Departments of Surgery and "Nephrology, Drechtsteden Ziekenhuis, Dordrecht and \#the Department of Surgery of the University Hospital, Maastricht.

European Journal of Surgery, in press. 
Objective - To formulate a standard for assessing functional patency of vascular access and to present long-term results of vascular access in a group undergoing dialysis, in particular the effects of percutaneous transluminal angioplasty (PTA).

Design - Retrospective study 1971-1980. Prospective study 1981-1991. Setting - A unit for haemodialysis in a regional hospital.

Subjects - All 259 patients treated from 1971 to 1991 in a programme for chronic haemodialysis.

Interventions - All interventions, surgical and radiological, needed to maintain vascular access.

Main outcome measures - Intervention free periods, patency of access, life expectancy of access, and early failure rate ( within 4 days). Patency of access before and after PTA.

Results - A total of 1179 interventions were made. 407 Arteriovenous (A.V) fistulas and shunts were constructed, and there were 519 surgical reoperations and 253 PTAs. The secondary cumulative patency rate for the autogenous distal A $\vee V$ fistulas (Cimino) was $79 \%$ at one year, $68 \%$ at two years and $59 \%$ at three years. Routine use of PTA from 1986 onwards resulted in a rise in secondary cumulative patency for Cimino A-V fistulas after two years from $65 \%$ to $80 \%$ ( $\mathrm{p}>0.05$ )

Conchusions - To describe and assess vascular access the patency rate alone is not sufficient; intervention free periods and life expectancy must also be given. Routine use of PTA. with the Cimino A.V fistula resulted in an appreciable but not significant increase patency at two years. 


\section{INTRODUCTION}

Adequate vascular access is the lifeline for a patient on haemodialysis. Access to the bloodstream can be obtained by surgically created arteriovenous (A.V) fistulas or by shunts. For practical reasons, in this paper we will use the general term "shunt" when we refer to both A.V fistulas and shunts. As is well known, shunts are susceptible to complications that threaten their function. Adequate function must be estimated and that means measuring it in several ways. Measuring only patency is not enough.

In general vascular surgery successful attempts have been made to standardise the reporting of results $[16,17]$, but comparable standardisation has yet to be established in vascular access surgery. Such reporting is needed to reach a consensus about the right methods in vascular access surgery. Two international congresses on access surgery have advanced the development of such a consensus [9,19].

As any criterion of the survival of a shunt has its limitations $[16,17,2]$, a truer picture of the results of access surgery is obtained when more than one criterion is used $[1,12,14,18]$. The intervention-free intervals for access shunts are important for patients because they influence their well-being. They also reflect the complication rate. The cumulative patency rate of a particular group of shunts, including the salvage operations, is relevant because it accentuates the possibilities of main taining vascular access, so sparing other locations. The life expectancy of a group of shunts, assumed to be equivalent to its median secondary survival, might be used to emphasise the potential survival of a shunt.

Early failure is a standardised concept in general vascular surgery, and means failure within the first days (up to a month) of a vascular operation. In access surgery, it is possible to be exact about failure. An access is used at intervals of no more than four days and each time the function is established beyond any doubt. It is, therefore, reasonable to define the upper limit for early failure as four days from the intervention. Because of its superficial position, function of the access can be monitored better than most other vascular interventions.

We report the results of access surgery in one centre for haemodialysis in a regional hospital over a period of 20 years during which time the same surgeon did most of the access surgery. From the beginning all relevant date about the procedures as well as the follow-up information were stored in prospectively and a standard way in a structured data base. The following changes in practice occurred in the course of the study period: after a period in which the arteriovenous shunt (Scribner) 
was the first choice access, there was a period when most accesses were converted to A.V fistulas -1974-. Graft fistulas were than introduced (in this department the autogenous vein graft - 1976 - and the expanded polytetrafluoroethylene (PTFE) graft - 1978 -), and extended the possibilities of second choice access. Finally, percutaneous transluminal angioplasty (PTA) $[4,6,7]$ was introduced as routine treatment for stenoses in arteries, veins and anastomoses of all shunts - 1985 - and this started a new era. These changes in policy over time have been taken into consideration in the analysis of our results.

The aim of this study was to propose standards for reporting on vascular access surgery, and to report our results of vascular access surgery over a 20 year period using these standards.

\section{PATIENTS AND METHODS}

\section{Patients}

All patients, who had been enrolled in the programme for chronic haemodialysis in the department of dialysis of the Drechtsteden Ziekenhuis in Dordrecht from 1971 to 1991 were registered and each intervention for vascular access was recorded. All shunts were included in the study (Table 1). The mean age rose from 35 years in the early 1970s to 44 years in 1980 and 56 years in 1990. Within the group of

Table 1. Details of the 290 patients entered in the study, 1 March 1971 - I November 1991. Figures are number (\%) unless otherwise stated.

\begin{tabular}{ll}
\hline Variable & No (\%) \\
\hline Sex: Male & 123 \\
$\quad$ Female & 97 \\
Mean age at start of dialysis (years) & 76 \\
$\quad$ Range & $7-80$ \\
Causes of end stage renal disease: & $51(23)$ \\
Chronic glomerulonephritis & $29(13)$ \\
Polycystic kidney disease & $18(8)$ \\
Chronic interstitial nephritis & $16(7)$ \\
Diabetes mellitus & $16(7)$ \\
Glomerulosclerosis & $14(6)$ \\
Chronic pyelonephritis & $76(35)$ \\
Other & 4.5 \\
Mean duration of chronic haemodialysis (years)
\end{tabular}


patients on chronic haemodialysis, 82 renal transplantations were done during this time.

\section{The centre}

The Department for Dialysis is a regional centre, that serves 354000 people and it includes a centre for home dialysis. Since 1990 we have had a growing number of patients who were treated with continuous ambulatory peritoneal dialysis (CAPD). The number of patients on haemodialysis rose steadily to 40 around 1980 and to 60 around 1990 .

\section{Definitions}

Primary survival: the time between the construction of a vascular access and its first failure.

Secondary survival: the time between the construction of a vascular access and its ultimate failure, all interim interventions included.

Patency: confirmed blood flow with sufficient function of the vascular access.

Cumulative primary patency: the percentage of shunts, that were functioning without salvage interventions of the total number of shunts at risk at any one time.

Cumulative secondary patency: the percentage of shunts, that were functioning with all salvage interventions included of the number of shunts at risk at any one time.

Failure: function of a vascular access inadequate.

Early failure: failure of a vascular access within four days (called also "initial failure") [2].

Intervention: any type of operation to create or maintain vascular access including percutaneous transluminal angioplasty.

Intervention-free period: the time between an intervention or reintervention and its failure.

Life expectancy: median value of secondary survival.

First choice access: a distal autogenous radiocephalic A.V fistula (for example a Cimino-Brescia fistula) or an A-V shunt (for example a Scribner shunt) when it was the surgeons first choice and not chosen because a Cimino fistula was impossible (sometimes also called "primary access"). Second choice access: al! those accesses constructed when the first choice access was impossible. These accesses include the graft A.V fistulas, the proximal autogenous A.V fistulas and the A.V shunts made as a second choice (also sometimes called "secondary access").

Revision: all those procedures that do not essentially change the type of a shunt. 


\section{Revision of sbunt or new shunt}

An access is generally regarded as having the same continuing function when it has been opened up without an operation (for example opening up a Scribner shunt) or treated with PTA; a simple thrombectomy does not change the status of an access. An operative transluminal angioplasty or a patch graft for stenosis also leaves the shunt in much the same state. A step further is a new anastomosis in an A-V fistula while the veins that are punctured remain the same. There is no real difference between a patch graft for a short stenosis and a small bypass. when the bypass is not meant to be punctured. for access. The line between a revision and a new shunt is drawn when the bypass itself is meant to be punctured.

\section{Statistical methods}

Calculations about the survival of the shunts were made with the help of a database for vascular access created by one of the authors (SAK) together with the Statistical Package for the Social Sciences (SPSS) [13]. Because it was likely that the distribution of the shunt survival was skewed, median values are presented. As mean values were used in some cases, these have been added in parentheses. The cumulative patency rate was calculated by Kaplan-Meyer survival analysis. From these data we used monthly intervals for the first year and yearly intervals thereafter. For the statistical analysis of the difference between median values of the different shunt groups and the patency rates we used the Mann Whitney test.

The survival of a shunt ends at the moment that occlusion or another stenotic complication prevents its use. After successful transplantation, or death of the patient, the shunt does not count any more. Transplan. tation, death and discontinuing dialysis with a functioning shunt implies that the patients were censored - that is, that they were regarded as no longer at risk - and so they were excluded from the study from that date.

\section{Percutaneous transluminal angioplasty}

Primary and secondary shunt survival, before and after the start of routine PTA, are presented separately. The influence of the availability of PTA on primary and secondary survival of each type of fistula or shunt was assessed by comparing the survival of the fistulas created in the last two six year periods of the study, During the first period, (1980 1985), PTA was not available. In the second period (1986 - october 1991) PTA was an additional means of dealing with serious stenosis 
of a fistula. The indications for intervention in both periods were assumed to be equal. Venous pressure and arterial flow measured during haemodialysis, were routinely followed. Bloodflow of less than $300 \mathrm{ml} / \mathrm{min}$ and venous pressure of more than $150 \mathrm{mg} \mathrm{Hg}$ was regarded as abnormal. When abnormal values persisted an angiography was done followed by an intervention. A PTA was always attempted in a case of a stenosis. Fistulas created during the first period that required PTA during its follow. up period were excluded from the comparison, so, 262 PTAs were done in 65 patients, who had had $72 \mathrm{~A} \cdot \mathrm{V}$ fistulas or shunts. Early failure was calculated for the different shunt groups and also for the reinterventions.

No lifetable values are given if the SE was $10 \%$ or more.

\section{RESULTS}

Over a period of 20 years, 220 first A.V fistulas and shunts and 187 subsequent ones were created in 220 patients. In total, 1179 interventions and reinterventions were done, including 262 PTAs.

A total of 208 autogenous Cimino-Brescia A.V fistulas at the wrist were constructed: 107 side to side, 96 end-to-side and 5 end-to-end. The 133 Scribner shunts were made with the Ramirez variation with an external bend. There were 46 graft A-V fistulas, among them 26 PTFE loop grafts, and 17 saphenous vein grafts (Table 2 ).

The primary cumulative patency rate for all shunts was $45 \%$ at one year, $29 \%$ at two years, $22 \%$ at three years, $19 \%$ at four years and $17 \%$ at five years (Figs 1 and 2). For the Cimino A-V fistula, these figures were $53 \%, 36 \%, 24 \%, 18 \%$ and $14 \%$; for the graft A.V fistula $37 \%, 21 \%$, $17 \%$ and $16 \%$; and for the Scribner A.V shunt for the first two years $18 \%$ and $6 \%$ respectively.

Table 2. Primary and secondary survival between 1971 and 1991 of A.V fistulas and shunts. Results are expressed as median (mean).

\begin{tabular}{lcll}
\hline Shunt & Number & $\begin{array}{l}\text { Primary survival } \\
\text { (days) }\end{array}$ & $\begin{array}{l}\text { Secondary survival } \\
\text { (days) }\end{array}$ \\
\hline Cimino A. V fistula & 208 & $364(669)$ & $630(1027)$ \\
Scribner A.V fistula & 133 & $78(178)$ & $231(531)$ \\
Graft A.V fistula & 6 & $238(436)$ & $457(888)$ \\
Total & 387 & & \\
\hline
\end{tabular}




\section{Numbers}

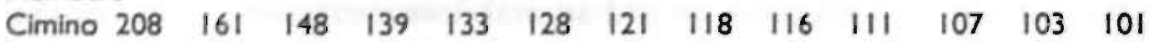
$\begin{array}{lllllllllllll}\text { Scribner } 133 & 91 & 72 & 58 & 48 & 42 & 39 & 36 & 32 & 31 & 28 & 26 & 23\end{array}$ $\begin{array}{llllllllllllll}\text { Graft } & 46 & 32 & 28 & 27 & 25 & 23 & 23 & 22 & 20 & 20 & 18 & 18 & 17\end{array}$

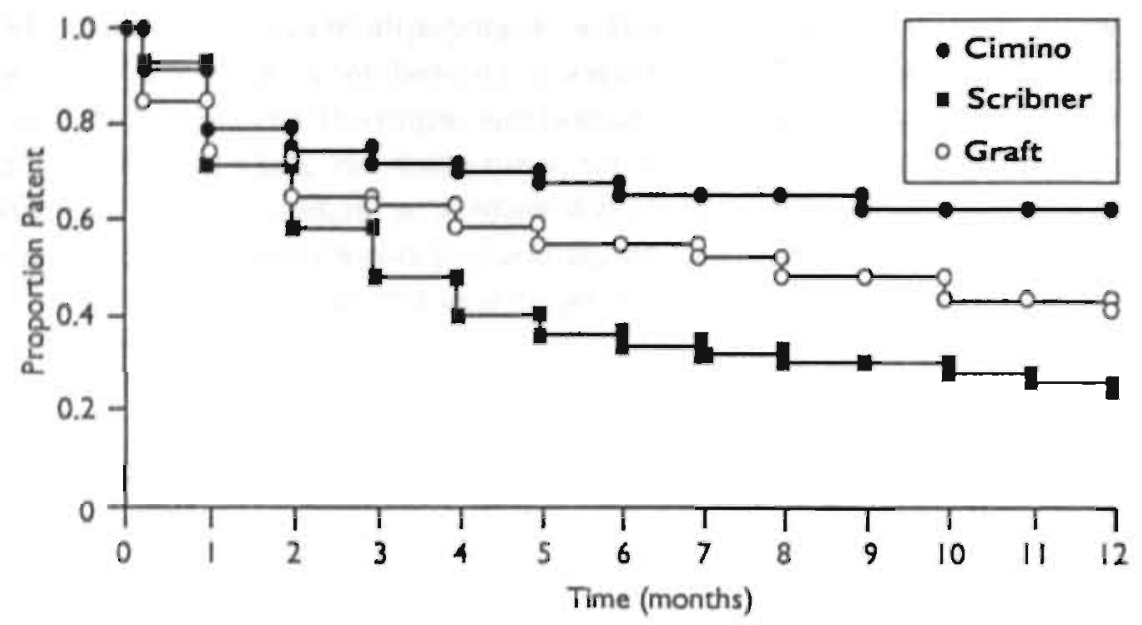

Figure 1. One year cumulative primary patency of A.V Cimino and graft fistulas and A. V Scribner shunts.

Number

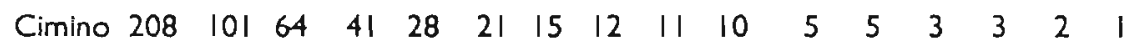
Seribner $133 \quad 23 \quad 7 \quad 2 \quad 1$ $\begin{array}{llllllll}\text { Graft } & 46 & 17 & 9 & 4 & 4 & 4 & 1\end{array}$

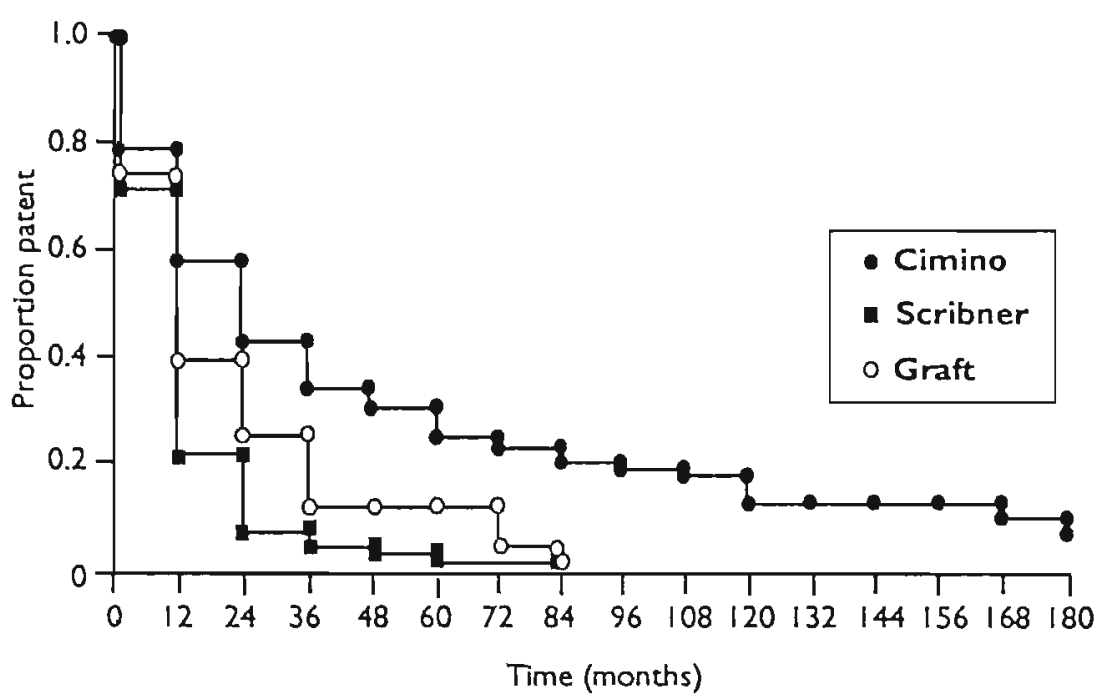

Figure 2. Long term cumulative primary patency of A.V Cimino and graft fistulas and A.V Scribner sbunts. 


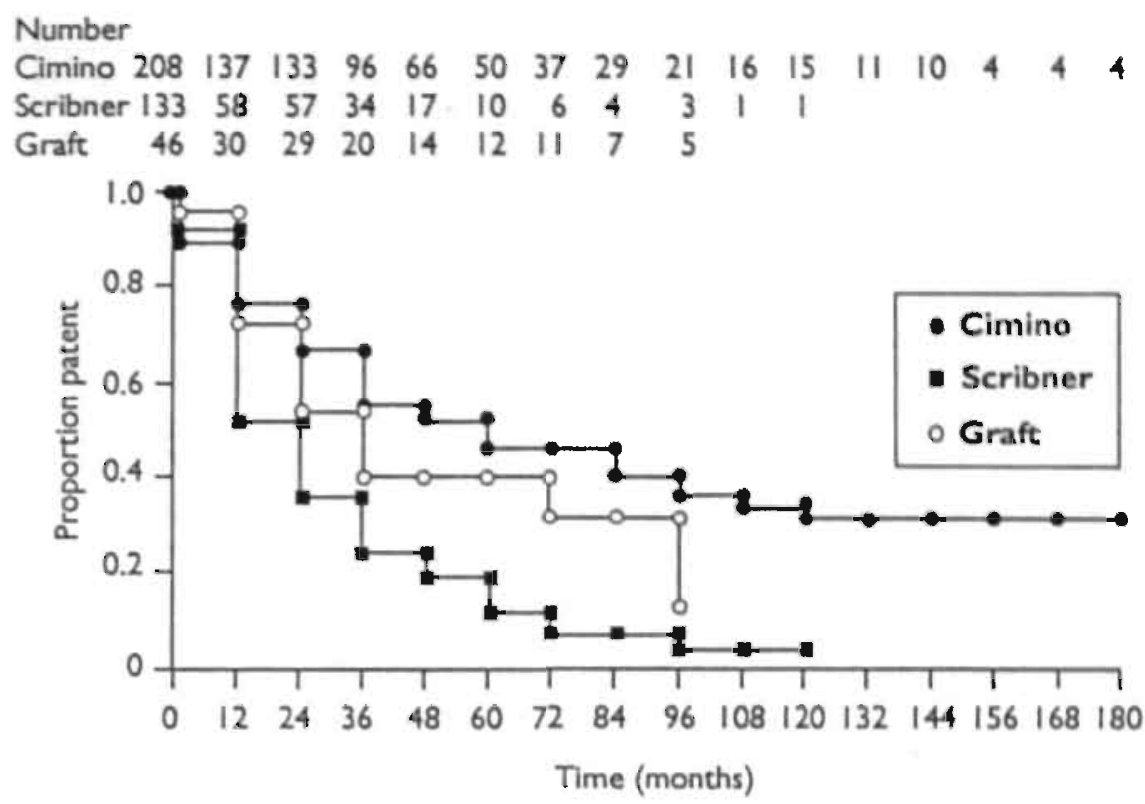

Figure 3. Long term cumulative secondary patency of A.V Cimino and graft fistulas and A.V Scribner shunts.

The secondary cumulative patency rate for all shunts, including early failures, was $69 \%$ at one year, $58 \%$ at two years, $48 \%$ at three years, $43 \%$ at four years and $39 \%$ at five years. There was a $28 \%$ survival rate at 10 years (Fig 3). For the Cimino A.V fistula, the secondary cumulative patency was $79 \%$ at one year, $68 \%$ at two years, $59 \%$ at three years, $55 \%$ at four years and $52 \%$ at five years, respectively. For the graft A.V fistula, these figures were $61 \%, 60 \%, 54 \%, 32 \%$ and $31 \%$ and for the Scribner A.V shunt $47 \%, 46 \%, 28 \%, 13 \%$ and $9 \%$.

The median intervention-free period for all shunts during the whole observation period, including every single intervention, was 80 days (mean 287, range 0-5701). For surgical interventions only, the value was 99 days (mean 335, range 0.5701 ).

The median secondary patency of the Cimino A-V fistulas was 836 days (mean 1044, range 0-6025), of Scribner shunts 262 days (mean 517, range 0-2827), of saphenous vein graft fistulas 510 days (mean 963 , range 0.3264 ) and of PTFE graft fistulas 506 days (mean 839 , range 0 3041). The median primary and secondary patency of all types of shunts is given in Table 3 .

Complications that required reinterventions are listed in Table 4 . Stenosis in the shunt vein was the most common complication, and 
Cbapter 4

Table 3. All 407 shunts constructed between March 1971 and December 1991.

\begin{tabular}{|c|c|c|c|}
\hline Type of shunt & $\begin{array}{l}\text { No }(\%) \text { of } \\
\text { shunts }\end{array}$ & $\begin{array}{l}\text { Median secon- } \\
\text { dary survival } \\
\text { (days) }\end{array}$ & $\begin{array}{l}\text { Mean, (range) of } \\
\text { survival } \\
\text { (days) }\end{array}$ \\
\hline Cimino $S$ to $S$ A.V fistula & $107(26)$ & 478 & $\begin{array}{l}927 \\
(0.5780)\end{array}$ \\
\hline Cimino E to S A.V fistula & $96(24)$ & 867 & $\begin{array}{l}1159 \\
(0-6025)\end{array}$ \\
\hline Cimino $E$ to E A V fistula & $5(1)$ & 96 & $\begin{array}{l}754 \\
(3-2480)\end{array}$ \\
\hline Scribner A.V shunt & $133(33)$ & 231 & $\begin{array}{l}513 \\
(0-2824)\end{array}$ \\
\hline PTFE loop A V fistula & $26(6)$ & 506 & $\begin{array}{l}839 \\
(0-3041)\end{array}$ \\
\hline PTFE straight A V fistula & $2(0.5)$ & 344 & 318 and 370 \\
\hline Saphenous vein A.V fistula & $17(4)$ & 510 & $\begin{array}{l}963 \\
(0-3264)\end{array}$ \\
\hline Proximal arm A.V fistula & $12(3)$ & 185 & $\begin{array}{l}568 \\
(50-4583)\end{array}$ \\
\hline $\begin{array}{l}\text { Biocarbon or Hemasite }{ }^{*} \mathrm{~A} \cdot \mathrm{V} \\
\text { shunt }\end{array}$ & $4(1.0)$ & 135 & $\begin{array}{l}691 \\
(25 \cdot 2469)\end{array}$ \\
\hline $\begin{array}{l}\text { Basilical vein transposition } \\
\text { A.V fistula }\end{array}$ & $4(1.0)$ & 82 & $\begin{array}{l}374 \\
(12-1029)\end{array}$ \\
\hline Varivas A.V fistula & $1(0.2)$ & 2051 & 2051 \\
\hline Total & $407(100)$ & 465 & $\begin{array}{l}827 \\
(0-6025)\end{array}$ \\
\hline
\end{tabular}

Table 4. Complications of vascular access surgery that required intervention between 1971 and 1991.

\begin{tabular}{lcc}
\hline Complication & No of interventions & Incidence (\%) \\
\hline Stenosis shunt vein & 257 & 29.8 \\
Thrombosis of unknown cause & 178 & 28.2 \\
Stenosis anastomosis & 47 & 5.5 \\
Venous hypertension & 7 & 0.8 \\
Steal syndrom & 4 & 0.5 \\
Aneurysm & 7 & 0.8 \\
Infection & 8 & 0.9 \\
Bleeding & 15 & 1.7 \\
Ulcer & 23 & 2.7 \\
Sienosis venous outifow Sctibner A.V shunt & 243 & 28.2 \\
Stenosis arterial inflow Scribner A.V shunt & 69 & 8.0 \\
Disconnection Scribner A.V shunt & 3 & 0.3 \\
\hline
\end{tabular}


in the Scribner A-V shunts, stenosis at the vessel tip was common. Thrombosis without a known cause was the second most frequent complication. Infection was a rare indication for operation.

The early failure rate for all new shunts was $4.9 \%$, for Cimino fistulas 6.3\% and for Scribner shunts 1.7\%. That for surgical reinterventions was $27 \%$ and for PTAs was 13\%.

After introduction of routine PTA the two year cumulative secondary patency rate rose from $65 \%$ to $80 \%$ for the Cimino AV fistulas ( $p>$ $0.05)$. Primary patency was shorter after PTA was started ( $<<0.05$; Table 5). Comparison of experience before and after PTA was introduced for the other shunts was not useful, because the numbers were too small (the graft fistulas) or there had been changes in indications over time (the Scribner shunts).

Table 5. Primary and secondary cumulative patency of the Cimino AV fistula before and after routine application of PTA.

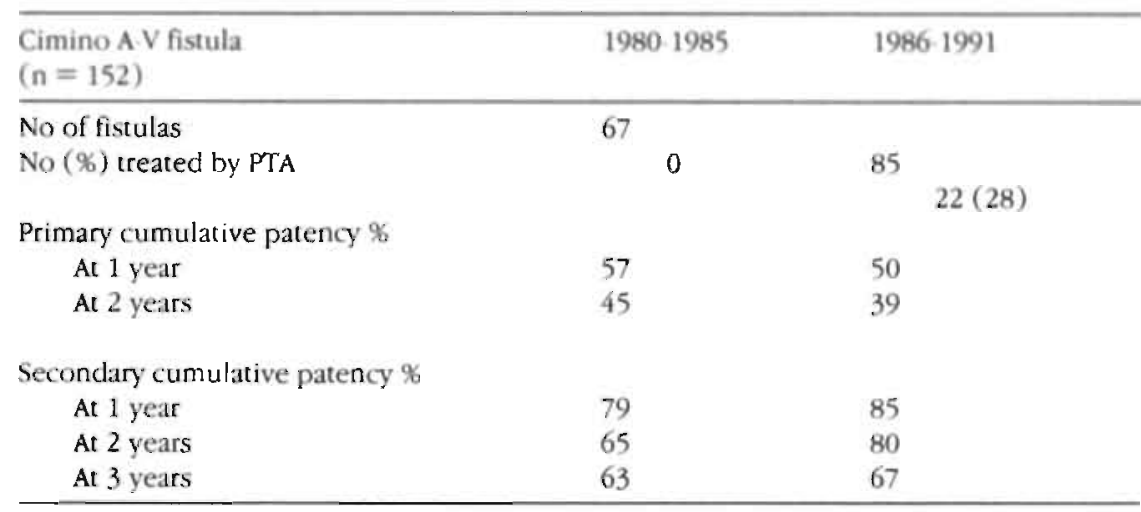

\section{DISCUSSION}

Survival of vascular access for haemodialysis, expressed as its functional patency, can be judged with certainty as long as the access is in use. Calculation of the patency of a vascular access for haemodialysis is more accurate than that of other vascular reconstructions, becaluse the regular use of fistulas and shunts establishes beyond any doubt their patency and function.

Our definition of "a new shunt" is clear, but is open for discussion. A partial replacement of a shunt vein by an implant, which can be punctured for access, means a new shunt. This situation is common after a long period of puncturing the vein, which has caused stenosis 
and if PTA has been used to treat the stenosis, after repeated dilatations. Partial substitution of a shunt vein by a graft (more a renovation than a totally new shunt, as it can be used immediately by puncturing the preserved part of the shunt vein), can mean satisfactory access. According to our definition it must be recorded as a new shunt.

Complications of vascular access surgery had been reported to be mainly stenosis, thrombosis and infection. A strict aseptic regimen and treatment with an antibiotic if infection developed resulted in few surgical interventions for infection.

In publications about the Scribner shunt, its survival is supposed to end when reimplantation is required [8]. Usually this involves the venous cannula, although of course the whole shunt can be lost. It has been said that the survival of a Scribner shunt is equivalent to its primary patency. We propose that reimplantations in the same veins and arteries be regarded as revisions, just as dilating a stenosis in an arteriovenous fistula by a patch graft is a revision. To make a comparison with other studies about the Scribner shunt possible, one must realize that in most reports secondary patency has not been distinguished from primary patency.

The relatively common use of the Scribner A.V shunt in this series requires comment. The arguments for using the Scribner shunt as a semipermanent access when there is, as yet, no A.V fistula available, are that it is a dependable access that can nearly always be constructed with a low early failure rate $(1.7 \%)$; it can be used immediately and can function for a number of months, if needed, without the risk of compromising an upper central vein; and if well cared for, it poses few problems and, with the help of PTA for stenoses at the vessel tip, it can survive while a long term access is created. We recommend the Ramirez variation with straight subcutaneous tubing and, near a joint, an extracutaneous bend. It makes catheterisation (for example for a PTA) much easier. The risk of problems with central veins in a patient, who may be dependent for years on an access in one arm makes us reluctant to catheterise a subclavian or jugular vein for vascular access haemodialysis [5]. Femoral vein catheterisation (Shaldon) [20] can be used but only for short periods.

A comparison of the results of different periods when a certain policy was in force (for example, using autogenous saphenous vein as a first choice interposition graft) is of limited value because of the small number of shunts involved, the length of the periods and the number of other variables. The effect of changing policies has its limits and makes comparison difficult. 
The reason that primary shunt survival was lower after the start of routine PTA is that stenoses were treated earlier by PTA. Secondary shunt survival ofthe whole group of A-V fistulas was longerafter 1986 but not significantly so), although there was no other change in treatment. Whenever a stenosis was diagnosed, a PTA was attempted and this resulted in treatment of $28 \%$ of all A.V fistulas by PTA. It seems probable that the combination of operation and PTA is more effective in prolonging the survival of A.V fistulas than operation alone, and our results are similar to those of a recent study from a experienced group in France [21]. They calculated patency after radiological interventions only. For the Scribner A-V shunt the primary and secondary survival rates were significantly lower during the last six years. There has been a change in the use of these shunts in the that they are now used for a shorter time, so one should not conclude that PTA for Scribner A.V shunts results in shorter survival. The data have been given, to show a complete picture of our recent results including the Scribner shunts.

Table 6. Survey of cumulative secondary patency rates (in percentages) of the autogenous distal A.V fistula reported by other authors. Patency at 4 weeks is given in parentheses. "Snuff box A-V fistula. " Some authors probably, after having reported early failure, report patencies of the remaining group of fistulas. ** Routine FTA used when indicated (1986. 1991).

\begin{tabular}{|c|c|c|c|c|c|c|c|}
\hline \multirow[t]{2}{*}{ First author } & \multirow{2}{*}{$\begin{array}{l}\text { Reference } \\
\text { No }\end{array}$} & \multirow{2}{*}{$\begin{array}{l}\text { Patent at four } \\
\text { days }\end{array}$} & \multicolumn{5}{|c|}{ Time (years) } \\
\hline & & & 1 & 2 & 3 & 4 & 5 \\
\hline $\begin{array}{l}\text { Bonalumi } \\
(n=177)\end{array}$ & 3 & 88.8 & 83.1 & 78 & 70 & & 52.5 \\
\hline $\begin{array}{l}\text { Reilly } \\
(\mathrm{n}=145)\end{array}$ & 15 & (90) & 80 & 75 & 72 & 65 & \\
\hline $\begin{array}{l}\text { Palder } \\
(n=99)\end{array}$ & 14 & $(76)$ & 60 & & 42 & & \\
\hline $\begin{array}{l}\text { Ota } \\
(n=865)\end{array}$ & 13 & 97 & & & & & 76.5 \\
\hline $\begin{array}{l}\text { Landmann } \\
(n=148)\end{array}$ & 10 & & 65 & & 60 & & \\
\hline $\begin{array}{l}\text { Landmann } \\
(\mathrm{n}=216)\end{array}$ & 10 & & 74 & & 64 & & \\
\hline $\begin{array}{l}\text { Wehrli } \\
(n=181) *\end{array}$ & 29 & $(88.8)$ & 88.7 & & 60.2 & & 36.6 \\
\hline $\begin{array}{l}\operatorname{Marx} \\
(\mathrm{n}=1476)\end{array}$ & 11 & & 65 & & & & \\
\hline $\begin{array}{l}\text { Present study } \\
(n=208)\end{array}$ & & 93.7 & 79 & 68 & 59 & 55 & 52 \\
\hline $\begin{array}{l}\text { Present study } \\
(n=85) * *\end{array}$ & & 93.8 & 85 & 80 & 67 & & \\
\hline
\end{tabular}


We define early failure as failure within four days. Others have defined it as failure within four weeks. It can be argued that four weeks is a reasonable period to decide whether an A.V fistula will function, but it is an arbitrary choice because many fistulas need a longer time to ripen and may still be used. We have analysed the time of failure of shunts and have shown that in our series a certain, steady percentage of A.V fistulas failed, after a larger number during the first days. The early failure rate can be kept low when little risk is taken with the shunt veins. On the other hand, trying to establish an A.V fistula with a doubtful prognosis can cause real harm to a patient. The high early failure rate for surgical reinterventions (27\%) may reflect poor selection, because in the case of stenoses PTA is attempted first; it also, however, reflects the wellknown problems of salvage operations.

Reported results are not easy to compare, but they do give some indication of the figures involved. Even the first choice access, the radiocephalic A.V fistula (Cimino- Brescia), regarded by every author as the best one, is not easy to compare. A survey of survival data is offered (Table 6), that shows the difficulty in comparing different studies $\{3,10-12,14,22\}$ and puts our results in perspective. There are interesting differences in the patency rates reported in the various studies. They may be related to the patient group, the surgeons, or the users of the shunts, but the patency rates are of the same order; this suggests that the results can reasonably be achieved.

\section{CONCLUSIONS}

We have proposed a standardised way of reporting vascular access surgery and have tested it on actual figures in our practice. We can draw the following conclusions: The radiocephalic A-V fistula has, over many years, consistently proved to be the vascular access with the best survival. PTA seemed to improve secondary survival rates of the radiocephalic A.V fistula, but not statistically so. The fact that in only $28 \%$ of the Cimino $A \cdot V$ fistulas the indication for a PTA arose, means that beneficial effects can only become significant when a large group is studied for a longer period. The A-V shunt (Scribner) has a place as a semipermanent vascular access with a reasonable secondary survival when treated with PTA as soon as clinically important stenoses occur.

\section{Acknouledgments}

We thank Jan Zijlstra, who has beeñ pioneering percutaneous transluminal angioplasty for vascular access in our clinic and in the Neth. erlands and Pamela Falger for her language editing. 


\section{REFERENCES}

1. Aman LC, Smith DW, Oh HK, Levin NW. Vascular access survival in diabetic and non-diabetic haemodialysis patients. In: Kootstra G, Jorning PJG, eds. Access Surgery. Lancaster: M.T.B. Press, 1983: 179-190.

2. Armitage P, Berry G. Statistical methods in medical research. 2nd ed. Oxford, Blackwell Scientific Publications, 1987: 421-38.

3. Bonalumi U, Civalleri D, Rovida S, Adami GF, Giannetta E, Griffanti-Bartoli F. Nine years experience with end to end arteriovenous fistula at the "anatomical snuffbox" for maintenance haemodialysis. Br J Surg 1982; 69: 486-488.

4. Burger H, Zijlstra J, Kluchent SA, Scholten AP. Percutaneous transluminal angioplasty improves longevity in. fistulas and shunts for haemodialysis. Nephrol Dial Transplant 1990; 5: 608-611.

5. Dupuy CA, Cavillon C, Houlgatte A, Mouton A, Angot M, Bourquelot P. Major proximal vein obstruction coexisting with angioaccess for chronic hacmodialysis. In: Tordoir JHM, Kitslaar PJEHM, Kootstra G, eds. Progress in access surgery. Maastricht: Datawyse, 1991: 88.92.

6. Glanz S, Gordon D, Butt K, Hong J. Lipkowitz G. The role of percutaneous angioplasty in the management of chronic hemodialysis fistulas. Ann Surg 1987; 206: 777.781 .

7. Gmelin E, Wintherhoff R, Rinast E. Insufficient Hemodialysis access fistulas: late results of treatment with percutaneous balloon angioplasty. Radiology 1989; 171: 657-660.

8. Ishihara AM, Myers CH. Longevity of arterio venous shunts for hemodialysis, Ann Surg 1968; 168: 281286

9. Kootstra G, Jorning PJG, eds. Access Surgery. Proceedings of the International Congress on Access Surgery, Maastricht 1982. Lancaster: MTP Press, 1983.

10. Landmann J. Die arterio venöse fistel für die chronische Haemodialyse. Helv Chir Acta 1987; 54:603-610.

11. Marx AB, Landmann J, Harder FH. Surgery for vascular access. Current Problems in Surgery $1990 ; 27: 28 \cdot 29$.

12. Norusis MJ. Statistical Package for Social Sciences 4.0 Manual. Chicago: SPSS Inc., 1990.

13. Ota K. The patency rate of various blood accesses. In: Ota K, ed. An atlas of vascular access. Edinburgh: Churchill Livingstone, 1987: 167.70.

14. Palder SB, Kirkman RL, Whittemore AD, Hakim RM, Lazarus JM, Tilney NL. Vascular access for hemodialysis: patency rates and results of revision. Ann Surg 1985; 202: 235-9.

15. Reilly DT, Wood RFM, Bell PRF. Prospective study of dialysis fistulas: Problem patients and their treatment. Br j Surg 1982; 69:549.553.

16. Rutherford RB, Presion FD, Gupta SK, et at. Suggested standards for reports dealing with lower extremity ischemia. J Vasc Surg 1986; 4: 80-94.

17. Rutherford RB. Standards for evaluating results of interventional therapy. Circulation 1991; 83 [suppl I] : 16 1-11.

18. Tordoir JHM, Kitslaar PJEHM, Kootstra G, eds. Progress in Access Surgery. Proceedings of the 2nd International Congress on Access Surgery, Maastricht 1990. Maastricht: Datawyse, 1990.

19. Tordoir JHM, Herman JMMPH, Kwan TS, Diderich PM Long term follow-up of the polytetrafluoroethylene (PTFE) prosthesis as an arteriovenous fistula for hemodialysis. Eur J Vasc Surg 1988; 2: 37.

20. Shaldon S, Chiandussi i., Higgs B. Haemodialysis by percutaneous catheterisation of femoral artery and vein with regional heparinisation. Lancet $1961 ; 2: 857-859$. 
Chapter 4

21. Turmel-Rodrigues L, Pengloan J, Blanchier D, et al. Insufficient Dialysis shunts: Improved long-term patency rates with close hemodynamic monitoring, repeated percutaneous balloon angioplasty and stent placement. Radiology 1993; 187: 273 . 278.

22. Wehrli $\mathrm{H}$, Chenevard $\mathrm{R}$, Zaruba $\mathrm{K}$. Chirurgische Erfahrungen mit arteriovenöse Haemodialyse-Shunts (1970-1988). Helv Chir Acta 1989; 56: 621-627. 


\section{CHAPTER 5}

\section{Cost Analysis of Vascular Access for Haemodialysis}

H. Burger, C. van Halem +, P. Heesters \#, F.Th. de Charro*

From the Departments of Surgery and \#Economics of the Drechtsteden Ziekenhuis, Dordrecht, the Faculty of Economics of the Free University of Amsterdam and "the Centre of Health Policy and Law of the Erasmus University of Rotterdam.

Submitted 


\section{ABSTRACT}

The costs of vascular access surgery make up a considerable part of the total costs of renal replacement therapy. For that reason they are the subject of the present study.

A permanent vascular access is needed for haemodialysis. In this report, the costs of access surgery as well as those of specific interventions are calculated per patient per year.

The method of percutaneous transluminal angioplasty (PTA) has increasingly become a useful adjuvant in the treatment of stenoses in arteriovenous fistulas and shunts. The costs of establishing and maintaining vascular access before and after the routine application of PTA are analysed by comparing two periods: 1980-1985 and 1986-1991. PTA, when routinely used, carries with it added costs, in particular for secondary access procedures. Then again, secondary access, with its higher costs and complications rates, may be postponed or even averted by using PTA. Overall costs per patient per year for creating and maintaining vascular access, surgery and PTA were about USD $3640^{*}$ (Dfl 6500 ), or $7.9 \%$ of the costs of haemodialysis during the period 1986 . 1991. For Cimino A-V fistulas alone these overall costs amounted to USD 1600 (Dfl 2850) per patient per year over the last 6 years. Yet, for less than USD 785 (Dfl 1400) extra per patient per year, the Cimino A.V fistulas prolonged cumulative survival of the access by $7 \%$ in the first year and by $15 \%$ in the second year when PTA was used as an adjuvant to surgery.

- 1 United States Dollar (USD) $=1.8$ Dutch guilders (Dfl); 1 Dfl $=0.56$ USD 


\section{INTRODUCTION}

A precondition for haemodialysis is the presence of a long term or permanent vascular access that will allow an adequate supply of blood to flow through the artificial kidney. Scribner et al. were in 1960, the first to make a permanent vascular access by implanting Teflon vessel tips in an artery and a vein and linking the two outside the skin with silicon rubber tubing, the arteriovenous (A.V) shunt. In 1966, Cimino et al. devised the subcutaneous A.V fistula between the radial artery and the cephalic vein at the wrist as an effective vascular access. The superficial arterialised venous net could be punctured frequently for a long time, providing a sufficient flow of blood through the artificial kidney. This Cimino A.V fistula is still widely regarded as the best and probably the least expensive vascular access. When it is not possible to make an A.V fistula at the wrist, other possibilities are available, among them an A.V fistula that is more proximal, often at the elbow, or an A.V fistula with interpositioning of a graft, when suitable superficial veins are absent. Several graft materials have been tried, a transplanted vein of the patient, a transplanted vein of another person (homologous vein) or animal (heterologous vein or artery), or an artificial blood vessel e.g., extended polytetrafluoroethylene (PTFE). At the moment, the most frequently used graft material for a vascular access for haemodialysis is PTFE.

Treatment for end-stage renal disease (ESRD) presently includes haemodialysis, peritoneal dialysis, or kidney transplantation. On 1 January 19923318 people in the Netherlands (population at the time 15102 231) were on dialysis: 2454 on haemodialysis and 864 on peritoneal dialysis. Chronic haemodialysis is an important part of the treatment for ESRD and the costs for treating ESRD have been the subject of substantial rescarch. As chronic haemodialysis requires a permanent vascular access, an analysis of the costs of vascular access surgery is appropriate.

A cost-effectiveness analysis of treatment for ESRD in the Netherlands was carried out by De Charro in 1988 [1]. In that study the costs of centre haemodialysis (passive or active) were estimated as being USD 59475 (Dfl 106 206) per patient per year, based on "billing" figures, i.e., costs based on the reimbursement rates. The costs to society referred to later as "total costs" or "full costs" for active centre haemodialysis were calculated as being USD 43020 (Dfl 76 830) per patient per year and those for passive centre haemodialysis as USD 49240 (87 930) per patient per year. Home haemodialysis costs amounted to USD 36590 


\section{Chapter 5}

(65 340) per patient per year after an initial training period that cost of USD 49450 (Dfl 88 300) for the first year.

Some studies on the costs of ESRD have taken the role of access surgery into account [2-6]. Chapman et al. [5] published the results of a cost analysis of vascular and peritoneal access for ESRD in a community hospital. Their estimates, based mainly on reimbursement rates, were USD 19600 for haemodialysis per patient per year, with USD 18000 representing the approximate reimbursement rate per patient per year for dialysis, and USD 1600 the rate for vascular and peritoneal access. The costs of continuous ambulatory peritoneal dialysis (CAPD) were not lower than the costs of haemodialysis, owing to more complications in the CAPD group. The costs for the associated hospital care were most likely not included in the costs for access procedures but in the nonspecified costs for dialysis. Chapman et al. concluded that an initial access procedure of any sort carried a price tag of USD 2500 and that maintenance procedures cost about the same. The differences in costs per year for the different types of access were determined by the number of maintenance procedures and the survival rate of an access. In the thesis of Zijlstra [6], describing a cohort of patients on haemodialysis in a regional hospital, the costs of treating a stenosis in a dialysis shunt were calculated on the basis of direct costs, i.e., those directly attributable to personnel, material and doctor's fees. He then added the cost of the associated hospital stay, i.e., the average cost per bed per day, computed as the total hospital costs per year, divided by the product of 365 and the number of beds. The price of an operation for a stenosis in the vessels of an A.V fistula (including a 5 day stay in the hospital) was USD $720+(5$ $x$ USD 336) $=$ USD 2400 (Dfl 4290). For an A-V shunt, the price was USD $680+(5 \times$ USD 336$)=$ USD $2360($ Dfl 4220$)$.

In the medical literature, costs are frequently based on reimbursement rates. Economists are used to expressing the costs in terms of the value of the resources involved [1-5].

As costs can be attributed to specific procedures in various ways, there is a need to clearly define concepts involved in the calculation of costs. While medical economists have, of course, always been well aware of the pitfalls of cost analysis, their conclusions are often open to different interpretations. We will try to present different approaches in order to minimise prejudice.

As normally all hospital costs are included in the calculation of the cost per day of a hospital bed, the costs of hospital stays associated with vascular access operations are often exaggerated. Being able to separate the direct costs for the patient in a hospital bed from the costs 
allocated to the hospital bed is essential. The direct costs for a patient undergoing a relatively simple operation are fairly low. For a patient on dialysis or a patient who is being prepared for dialysis, there may be a number of reasons for prolonging the stay in the hospital that will most likely affect the costs incurred. Diagnostic tests, consultations with other specialists and special care in connection with ESRD generate additional hospital costs that are difficult to separate from the hospital costs incurred for the operation alone.

The use of percutaneous transluminal angioplasty (PTA) as an adjuvant to vascular surgery in treating vascular stenoses by balloon dilatation has signified the beginning of a new era in access surgery with beneficial effects for the patients [6-8]. Vascular accesses have a longer survival and require fewer surgical interventions thanks to PTA, which can nearly always be done on an outpatient basis. No length of blood vessel has to be sacrificed and PTA increases the quality of life for the patients on haemodialysis $[6,7,9]$. While the costs of treatment of coronary insufficiency by surgery and PTA have been compared [9], only a few publications make the comparison for surgery and PTA for access surgery. Brooks [11] calculated higher costs for PTA while Zijlstra [7] suggested cost savings. One of the aims of the present study was to further analyse data in order to confirm some of these earlier findings.

\section{MFTHODS AND MATERIAIS}

The costs of access procedures for haemodialysis were calculated in a regional centre for dialysis - the Department for Dialysis of the Drechtsteden Ziekenhuis in Dordrecht - over the 12-year period, from 1980 until 1991. Calculations were made on the basis of direct costs and total costs. Two periods - 1980-1985 and 1986-1991 - were compared to determine the effect of routine use of PTA on costs.

The costs of a stay in a hospital bed were calculated on the basis of the real costs, not of the reimbursement rate. The costs of the surgeon and the anaesthesiologist are always difficult to assess. While Dutch law sets fixed rates for doctors, these rates do not always adequately reflect services rendered. Yet, they are probably the best estimate available and include indirect costs. It should be noted that doctor's fees for a stateinsured patient are lower than those for a privately insured patient. Fees are averaged, making allowances for the ratio of privately versus stateinsured patients, which is now $33 \%$ versus $66 \%$. The costs of specific procedures, as well as the costs per patient per year, are calculated. 
Amounts of money totalling more than USD 100 are rounded off to the nearest USD 10.

\section{The centre}

In the course of 10 years, an evolution of the population of the centre took place. The number of patients on haemodialysis rose from 45 to 56. At the end of 1991, six patients were on CAPD. The average age rose from 46.6 to 56.5 years. The average treatment period remained fairly constant, ranging from 4 to 5.5 years. The duration of a hospital stay was calculated by taking the total period of hospitalization associated with the vascular access surgery and subtracting the period not attributable to surgery. All hospital stays in connection with access surgery were reviewed by the surgeon and, when in doubt, they were reconsidered by the nephrologists.

Patients in this department are normally dialysed three times a week or, in other words, 156 times per year. The costs per year per dialysis are well known, so the share of the costs attributed to access surgery can easily be calculated.

\section{Definitions}

Total cost (also called "full cost"): the sum of the direct costs and the indirect costs.

Costs based on reimbursement rates or "billing figures": the costs that the health care institutions that provide the funding pay to health care providers, according to the agreements that exist between the financing institutions and the health care providers.

Direct costs (also called "variable costs"): costs directly attributable to procedures.

Indirect costs: those nor directly attributable or traceable to procedures. Indirect costs can be allocated to procedures by means of different costing models.

Mark-up refers to the amount obtained by multiplying the direct costs by a certain percentage required to calculate the indirect costs. This percentage is different for each department and differs from year to year. First choice access: a distal autogenous radiocephalic A.V fistula (for example a Cimino-Brescia fistula) or an A-V shunt (for example a Scribner shunt) when it was the surgeons first choice and not chosen because a Cimino fistula was impossible (sometimes also called "primary access"). Second choice access: all those accesses constructed when the first choice access was impossible. These accesses include the graft $\mathrm{A} \cdot \mathrm{V}$ fistulas, the proximal autogenous $\mathrm{A} \cdot \mathrm{V}$ fistulas and the $\mathrm{A} \cdot \mathrm{V}$ shunts made as a second choice (also sometimes called "secondary access"). 
A-V shunt: generally means any type of vascular access (in the Index Medicus: arteriovenous shunt, surgical) in which an artery is linked to a vein and, in particular, a Scribner A.V shunt.

\section{RESULTS}

The costs of vascular access surgery were reported for two periods, 1980 1985 and 1986-1991. The number and type of all interventions, surgical

Table 1. The number of first and subsequent shunts, the number of surgical reinterventions, the number of PTA's on A.V fistulas and A.V shunts (Scribner), the total number of interventions, and the number of patients treated by haemodialysis in the Department for Dialysis of the Drechtsteden Ziekenhuis Dordrecht from 1980 until 1992.

\begin{tabular}{lcclcccc}
\hline Year & $\begin{array}{l}\text { First } \\
\text { shunts }\end{array}$ & $\begin{array}{l}\text { Subse- } \\
\text { quent } \\
\text { shunts }\end{array}$ & $\begin{array}{l}\text { Reinter } \\
\text { ventions } \\
\text { surgical }\end{array}$ & $\begin{array}{l}\text { PTA's A.V } \\
\text { fistula. }\end{array}$ & $\begin{array}{l}\text { PTA's } \\
\text { A.V shunt }\end{array}$ & $\begin{array}{l}\text { All inter } \\
\text { ventions } \\
\text { incl. PTA, } \\
\text { excl. first } \\
\text { shunts }\end{array}$ & $\begin{array}{l}\text { Number of } \\
\text { dialysis on }\end{array}$ \\
\hline 1980 & 6 & 12 & 25 & 0 & 0 & 37 & 39 \\
1981 & 12 & 14 & 35 & 0 & 0 & 49 & 41 \\
1982 & 8 & 15 & 45 & 0 & 0 & 60 & 45 \\
1983 & 11 & 11 & 37 & 0 & 0 & 48 & 46 \\
1984 & 8 & 9 & 40 & 0 & 0 & 49 & 49 \\
1985 & 12 & 6 & 36 & 0 & 0 & 42 & 47 \\
1986 & 13 & 11 & 23 & 5 & 1.3 & 52 & 45 \\
1987 & 16 & 6 & 27 & 1.3 & 20 & 66 & 54 \\
1988 & 12 & 7 & 24 & 20 & 23 & 74 & 54 \\
1989 & 13 & 9 & 27 & 23 & 20 & 79 & 55 \\
1990 & 12 & 8 & 40 & 36 & 34 & 123 & 50 \\
1991 & 20 & 19 & 44 & 39 & 38 & 140 & 56 \\
\hline
\end{tabular}

Table 2. Average duration of hospital stay in days for reinterventions - surgery and percutaneous transluminal angioplasty (PTA) - in vascular access (Cimino A.V fistula) in two periods: $1980-1985$ and $1986-1991$.

\begin{tabular}{lllll}
\hline Period & 1980.1985 & \multicolumn{3}{l}{$1986-1991$} \\
\hline Type of intervention & Surgery & PTA & Surgery & PTA and Surgery \\
\hline Days in hospital, average & 3.79 & 0.19 & 3.36 & 1.54 \\
$\begin{array}{l}\text { Days in hospital, } \\
\text { minimum-maximum }\end{array}$ & $0-60$ & $0-2$ & $0-15$ & $0-15$ \\
\hline
\end{tabular}




\section{Chapter 5}

Table 3. Total costs of creating and maintaining vascular access for hemodialysis (ind. stay in hospital) in the periods 1980-1985 and 1986-1991, taking into account the effects of routine adjuvant application of percutaneous transluminal angioplasty (PTA). Price level 1991.

\begin{tabular}{|c|c|c|c|c|}
\hline & \multicolumn{2}{|c|}{ 1980-1985 } & \multicolumn{2}{|c|}{$1986-1991$} \\
\hline Number of surgical interventions & \multicolumn{2}{|l|}{342} & \multicolumn{2}{|c|}{331} \\
\hline Number of PTA's & \multicolumn{2}{|c|}{0} & \multicolumn{2}{|c|}{286} \\
\hline Number of all interventions & \multicolumn{2}{|l|}{342} & \multicolumn{2}{|c|}{617} \\
\hline Average number of patients & \multicolumn{2}{|c|}{44.5} & \multicolumn{2}{|c|}{52.3} \\
\hline Sum of total costs of all access interventions & \multicolumn{2}{|c|}{ Dff 944340} & \multicolumn{2}{|c|}{ Dfl 2031830} \\
\hline Average total costs of any intervention & Dfl & 2760 & Df & 3290 \\
\hline Sum of total costs of surgical interventions & \multicolumn{2}{|c|}{ Df 944340} & Dfl & 881580 \\
\hline Average total costs of a surgical intervention & \multirow[t]{3}{*}{ Dfl } & 2760 & Df & 2660 \\
\hline Sum of total costs of PTA & & - & \multicolumn{2}{|c|}{ Df 1150250} \\
\hline Average total costs of a PTA & & - & Df & 4020 \\
\hline Costs per patient per year (surgery only) & \multirow[t]{2}{*}{ Dfl } & 3540 & Dfl & 2810 \\
\hline Costs per patient per year (PTA only) & & - & DA & 3670 \\
\hline Costs per patient per year (surgery and PTA) & Dfl & 3540 & Dfl & 6480 \\
\hline
\end{tabular}

Table 4. Costs of percutaneous transluminal angiopiasty of A V fistulas and Scribner A.V shunts. Price level 1991.

\begin{tabular}{lrc}
\hline & $\begin{array}{l}\text { PTA A V fistula } \\
\text { (Dfl) }\end{array}$ & $\begin{array}{l}\text { PTA scribner shunt } \\
\text { (Dfl) }\end{array}$ \\
\hline Schneider balloon catheter and guide wire & 1400 & 1890 \\
Disposables & 100 & 140 \\
All materials & 1500 & 2030 \\
Personnel ractiology & 60 & 60 \\
Personnel dialysis & 80 & 80 \\
All personnel & 140 & 140 \\
Fee radiologist & 390 & 390 \\
All direct costs (excl. doctor's fee) & 1600 & 2170 \\
Ail direct costs (incl. doctor's fee) & 2030 & 2560 \\
Mark up indirect costs personnel. 52.7\% & 70 & 70 \\
Mark up indirect costs materials, 111.3\% & 1670 & 2250 \\
All hospital costs indirect and direct & 3380 & 4990 \\
(excl. doctor's fee) & & 4880 \\
Total costs (incl. doctor's fee) & 3770 & \\
\hline
\end{tabular}


and radiological, were determined per year (Table 1). In the first period, 57 first shunts were created and 218 surgical reinterventions were needed for an average of $\mathbf{4 4 . 5}$ patients in the centre. In the second period, 86 first shunts were created and, 185 surgical reinterventions were done for an average of 52.3 patients. In addition, 266 PTA's (136 for A V fistulas and 148 for Scribner A.V shunts) were carried out in the second period. The average associated hospital stay for surgery was 3.79 days in the first period and 3.36 days in the second period. PTA's were usually carried out on an outpatient basis and required an average hospital stay of 0.19 days (Table 2). The total costs of a stay in the hospital in the nephrology ward were USD 130 (Dfl 230) per day in 1991, operations, dialysis and special treatments excluded. The total costs for a surgical intervention were slightly lower in the second period: USD 1600 (Dfl 2860) in the

Table 5. Costs of creating new Cimino A.V fistulas, Scribner A.V shunts, autologous saphenous vein (VSM loop), and PTFE graft A.V fistulas. Price level 1991.

\begin{tabular}{|c|c|c|c|c|}
\hline & $\begin{array}{l}\text { New } \\
\text { Cimino } \\
\text { fistula } \\
\text { (Dfl) }\end{array}$ & $\begin{array}{l}\text { New } \\
\text { Scribner } \\
\text { shunt } \\
\text { (Dfi) }\end{array}$ & $\begin{array}{l}\text { New VSM } \\
\text { loop } \\
\text { A V fistula } \\
\text { (Dfl) }\end{array}$ & $\begin{array}{l}\text { New PTFE } \\
\text { loop A V } \\
\text { fistula } \\
\text { (DA) }\end{array}$ \\
\hline Disposables & 190 & 190 & 190 & 190 \\
\hline Scribner-Ramirez shunt & & 230 & & 1270 \\
\hline All materials & 190 & 420 & 190 & 1460 \\
\hline $\begin{array}{l}\text { Personnel surgery and } \\
\text { anesthesia }\end{array}$ & 540 & 540 & 880 & 680 \\
\hline All personnel & 540 & 540 & 880 & 680 \\
\hline $\begin{array}{l}\text { Fee surgeon and } \\
\text { anesthesiologist }\end{array}$ & 640 & 430 & 1100 & 1110 \\
\hline $\begin{array}{l}\text { All direct costs } \\
\text { (excl. doctor's fee) }\end{array}$ & 730 & 960 & 1070 & 2140 \\
\hline $\begin{array}{l}\text { All direct costs } \\
\text { (incl. doctor's fee) }\end{array}$ & 1360 & 1390 & 2170 & 3240 \\
\hline $\begin{array}{l}\text { Mark up indirect costs } \\
\text { personnel, } 52.7 \%\end{array}$ & 280 & 280 & 460 & 360 \\
\hline $\begin{array}{l}\text { Mark up indirect costs } \\
\text { materials, } 111.3 \%\end{array}$ & 210 & 470 & 210 & 1630 \\
\hline $\begin{array}{l}\text { All hospital costs, direct } \\
\text { and indirect } \\
\text { (excl. doctor's fee) }\end{array}$ & 1230 & 1710 & 1740 & 4120 \\
\hline $\begin{array}{l}\text { Total costs. } \\
\text { (incl. doctor's fee) }\end{array}$ & 1860 & 2150 & 2840 & 5220 \\
\hline
\end{tabular}


second period versus USD 1650 (Dfl 2940) in the first period. The total costs per patient per year for vascular access in the second period, including hospital stay and PTA if needed, were USD 3620 (Dfl 6470) (Table 3).

Direct and indirect costs were computed for PTA's for A.V fistulas and for Scribner A.V shunts (Table 4). The same was done for the different surgical interventions used to reconstruct failing fistulas and shunts. Table 5 presents these calculations for the Cimino A.V fistulas, the Scribner A.V shunts, the autologous saphenous vein and the PTFE graft A-V fistulas. A summing up of the calculations of all types of surgical interventions performed to create or maintain dialysis accesses is presented in Table 6.

Table 6. Direct (excl. doctor's fee) and total costs (indirect and direct costs, incl. doctor's fee) of all surgical interventions for vascular access. Doctor's fee for surgeon and anesthesiologist. Price level 1991.

\begin{tabular}{|c|c|c|}
\hline & Direct costs (Dfl) & Total costs (Dfl) \\
\hline A.V fistula Cimino & 730 & 1860 \\
\hline A $V$ fistula elbow & 800 & 1950 \\
\hline A. $V$ shunt Scribner & 960 & 2150 \\
\hline A.V fistula PTFE loop graft & 2140 & 5220 \\
\hline A. V fistula saphenous vein loop graft & 1070 & 2840 \\
\hline A.V fistula PTFE straight graft & 2050 & 4960 \\
\hline Biocarbon or Hemasite access device & 2870 & 6760 \\
\hline Desobstruction & 730 & 1860 \\
\hline New $A \cdot V$ anasiomosis & 730 & 1870 \\
\hline New arterial implant Scribner A.V shunt & 780 & 1220 \\
\hline New venous implant Scribner A.V shunt & 710 & 1700 \\
\hline skin plasty & 360 & 880 \\
\hline Adhesiolysis & 460 & 1130 \\
\hline Patch PTFE & 900 & 2640 \\
\hline Patch venous & 870 & 2530 \\
\hline Bypass PTIE & 1270 & 3380 \\
\hline Bypass venous & 930 & 2630 \\
\hline Surgical balloon dilatation & 1210 & 2880 \\
\hline Aneurysm resection & 830 & 2540 \\
\hline Basilical vein transposition & 730 & 2320 \\
\hline Ligature of a vein & 360 & 840 \\
\hline
\end{tabular}


Table 7. Costs per year per patient of maintaining Cimino A V fistulas and second choice access in two periods: 1980-1985 and 1986-1991, and average number of patients, with second choice vascular access. Price level 1991.

\begin{tabular}{llc}
\hline & $1980-1985$ & $1986-1991$ \\
\hline $\begin{array}{l}\text { Surgical reinterventions for } \\
\text { Cimino A.V fistulas }\end{array}$ & Df 1480 & Df 1110 \\
PTA's for Cimino A V fistulas & Df 1740 \\
Total costs for Cimino A V fistulas & Df 1480 & Dfl 2850 \\
$\begin{array}{l}\text { Average number of patients with second choice access } \\
\text { and percentage of all patients }\end{array}$ & $15.7(35 \%)$ & $11.2(21 \%)$ \\
$\begin{array}{l}\text { Surgical interventions for second choice vascular access } \\
\text { PTA's for second choice vascular access }\end{array}$ & Df 4950 & Dfl 4870 \\
Total costs for second choice vascular access & Df 8600 \\
\hline
\end{tabular}

For the Cimino A.V fistula, a detailed cost analysis resulted in a cost of USD 830 (Dfl 1480) per patient per year for revisions in the first period (1980-1985) and of USD 1600 (Dfl 2860) (PTA included) for the second period (19861991) (Table 7). From the calculations it is evident that for an extra USD 770 (Dfl 1370) per patient per year, routine PTA can be carried out, resulting in prolonged survival of the Cimino A- $V$ fistula.

The costs of second choice access surgery were also computed (Table 7). In the first period (1980-1985), 140 interventions were done at a cost of USD 2780 (Df 4950) per patient per year. In that same period, $35 \%$ of the patients had a second choice access. In the second period, 101 surgical interventions were done at a cost per patient per year of USD 2730 (Dfl 4870). In addition to that, 120 PTAs were carried out, the majority on Scribner shunts, at a cost of USD 4820 (Dfl 8600) per patient per year. Creating and maintaining the second choice access carried a price tag of USD 7540 (Dfl 13 470) per patient per year for an average of 11 patients, or $21 \%$ of the whole group of patients on haemodialysis. 


\section{DISCUSSION}

Cost analysis of vascular access for haemodialysis should be considered in decisions involving the appropriate approach to the treatment of ESRD. As expected, first choice access surgery is less expensive than second choice access surgery. Second choice access surgery tends to be more difficult, may require an expensive vascular prosthesis and is associated with a longer stay in the hospital.

The duration of the hospital stay for vascular surgery cannot easily be calculated. One needs to take the recorded hospital stay associated with the period in which access surgery was carried out and then subtract the period not attributed to the vascular surgery. Thus, the surgeon must give serious thought to each case.

The evolution of the population in centres for dialysis in the Netherlands differs from one centre to the next but, in general, the tendency is towards older patients and those with a more compromised general health [10].

We determined that the patency rate for Cimino A.V fistulas increased by $7 \%$ in the first year and by $15 \%$ after two years with the use of PTA as a routine adjuvant procedure in the maintenance of fistula function [12]. However this increase in survival was not significant in a group of all 85 Cimino A.V fistulas during the period 1986-1991 compared with the period 1980-1985. Of these fistulas $28 \%$ was treated with PTA. Probably the numbers were still too small for significance. The extra costs incurred in order to achieve this improvement in fistula function were Dfl 1370 per patient per year.

While we conclude that routine application of PTA carries with it an extra cost of nearly Dfl 1400, we must also bear in mind that if no simple new Cimino AV fistula could be created, a second choice access would have to be made and this would cost considerably more. Besides second choice access has a shorter survival time. Therefore the high costs incurred by the routine use of PTA are at least partly offset by the higher costs of second choice access surgery. Maintaining a reduced number of second choice accesses in the second period (35\% of the accesses in the first period were second choice versus $21 \%$ in the second) was more costly when PTA was routinely used (Table 7) and these high costs were largely generated by repeated PTA's for second choice semipermanent scribner shunts for only a few patients. These shunts, which could otherwise only be replaced by semipermanent catheters, were maintained with few complications other than stenosis. The repeated PTA's were carried out on an outpatient basis. The overall costs. 
of maintaining second choice vascular access, surgery and PTA amounted to USD 7560 (Dfl 13500 ) per patient per year, or $16 \%$ of the costs of haemodialysis (USD 49 or Dfl 87 per dialysis).

Under the circumstances of acute need at the start of haemodialysis the costs of the Scribner A.V shunt as a semipermanent shunt would appear to be acceptable. For use in complicated situations during haemodialysis the shunt is helpful but the costs are relatively high when repeated PTAs are necessary to maintain its function.

As the PTFE graft A.V fistula is now probably the most popular second choice access procedure and may be the best according to literature with a good survival time [13], its costs, though higher than any first choice access, can still be considered acceptable. The cheaper autologous saphenous vein graft fistula is not often constructed, mainly because of limited availability of an adequate vein and of good patency rates only in the hands of some surgeons.

\section{CONCLUSIONS}

The costs per patient per year for vascular access aie about USD 3640 (Dfl 6500), or $7.9 \%$ of the costs of haemodialysis per year (USD 24 or Dfl 42 per dialysis).

The added costs of routine PTA as an adjuvant to maintain Cimino A.V fistulas are, on the average, USD 770 (DFL 1370) per patient per year. For these fistulas PTA may mean a savings since an expensive second choice access is not needed or can be postponed.

With PTA as an adjuvant to second choice access surgery, something which results in an improvement in the quality of life of the patients, costs incurred are higher, up to $16 \%$ of the cost of haemodialysis. Seeing as how other procedures are also expensive, in a limited number of cases a more costly but safe and reliable, method to maintain vascular access would still appear to be acceptable.

\section{Acknowledgements}

We wish to thank G. Schreurs, head of the medical archives, for his help in providing data regarding hospital stay. 


\section{REFERENCES}

1. Charro de FTh. [Cost-effectiveness analysis of the end stage renal disease program in The Netherlands]. [Dissertation] Rotterdam, 1988.

2. Jones KR. Factors associated with hospitalization in a sample of chronic hemodialysis patients. Health Serv Res 1991; 26: 671-699.

3. Croxson BE, Ashton T. A cost effectiveness analysis of the treatment of end stage renal failure. N Z Med J 1990; 103: 171-174.

4. Mandel SR, Martin PL., Blumoff RL, Mattern WD. Vascular access in a university transplant and dialysis program; results, costs, and manpower implications. Arch Surg 1977; 112: $1375 \cdot 1380$.

5. Chapman JE, Sinicrope RA, Clark DM. Angio and peritoneal access for endstage renal disease in the community hospital: a cost analysis. Am Surg 1986; 52: 315-319.

6. Zijlstra II. Percutaneous transluminal angioplasty in vascular access for hemodialysis. [Dissertation] Utrecht, 1989: 98-99.

7. Glanz S, Gordon DH, Butt KMH, Hong J, Lipkowitz GS. The role of percutaneous angioplasty in the management of chronic hemodialysis fistulas. Ann Surg 1987; 206: 77.81 .

8. Van den Brand M, Van Halem C, Van den Brink F, De Feyter P, Serruys P, Suryapranata H. Meeter K. Bos E, Van Dalen F. Comparison of costs of percutaneous transluminal coronary angioplasty and coronary bypass surgery for patients with angina pectoris. Eur Heart J 1990: 11: 765-771.

9. Burger H, Zijlstra IJ, Kluchen SA, Kootstra G. Long term results of routine application of percutaneous transluminal angioplasty as an adjuvant to access surgery. In: Progress in Access Surgery, Tordoir JHM, Kitslaar PJEHM, Kootstra G, eds. Maastricht: Datawyse, 1990: $165 \cdot 170$.

10. Burger H, Kootstra G, de Charro F, Leffers P. A survey of vascular access in The Netherlands. Nephrol Dial Transpl 1991; 6: 5 10.

11. Brooks U, Sigley RD, May KJ, Mack RM. Transluminal angioplasty versus surgical repair for stenosis of hemodialysis grafts. Am J Surg 1987; 153: 530-531.

12. Burger $H_{4}$ Kluchen SA, Kootstra G, Kitslaar PJEHM, Ubbink DTh. Survival of arte riovenous fistulas and shunts for haemodialysis. Eur J Surg 1994; in press.

13. Mueller Wieffel H. Graft AN fistulas. In: Progress in Access Surgery, Tordoir JHM, Kitslaar PJEHM, Kootstra G eds. Maastricht: Datawyse, 1990: 14-17. 


\section{GENERAL DISCUSSION AND CONCLUSIONS}

\section{INTRODUCTION}

Vascular access for haemodialysis has developed from its modest beginnings in the sixties to a specialised form of surgery. We have investigated the state of vascular access in the Netherlands, the impact of the use of the new technique of PTA and its overall effects on the survival of shunts. The costs of vascular access as a part of all the costs of the treatment of end-stage renal disease and the cost effects of percutaneous transluminal angioplasty in particular have been investigated.

\section{PRIMARY AND SECONDARY ACCESS}

There is an informal consensus that the autogenous radiocephalic (Cimino) A.V fistula should be the first choice for a good, long term vascular access [1]. Our study confirms this view.

Often, extensive medical treatment preceding dialysis results in a high percentage of patients with peripheral veins that are of insufficient quality for vascular access. In such cases, some surgeons will nevertheless try their utmost to create a Cimino A-V fistula. Others will choose a graft fistula when there is any doubt about the quality of the peripheral veins or arteries. In such cases, it is always difficult to prove that trying to create an $A \cdot V$ fistula is better than creating a graft fistula. Good overall results from clinics performing a high percentage of autogenous $\mathrm{A}-\mathrm{V}$ fistulas suggest that in less favorable cases it is also worthwhile trying to create a distal A-V fistula [2]. On the other hand, graft fistulas may function for a long time [3]. They are often easier to puncture and can be reconstructed by PTA or surgery if the need arises.

The right choice of graft material for a second choice A.V fistula has not yet been clearly established. Over the past years, there has been a steadily growing worldwide acceptance of PTFE as the graft material of choice [4]. Homologous vein grafts have not been used on a wide scale, but good long term results have been reported [5]. An autologous 
vein transplant makes for a very acceptable graft when the quality of the vein is good; however its application has become limited.

Our survey of the actual state of vascular access in the Netherlands supports the view that the choice of access is strongly influenced by personal preferences. No objective arguments can clarify the observed differences in choice for access.

A consensus about the right choices for vascular access and the correct techniques for the establishment and maintenance of vascular access is important. A working group for access surgery has been active in the Netherlands since 1990. This group takes an active part in organizing congresses and symposia to promote the quality of access surgery. Plans for a national registration of vascular access are being prepared with a view to promoting high standards for access surgery. Surgeons, nephrologists, radiologists and dialysis nursing staff all take part in this working group.

\section{STANDARDISED REPORTING ON THE RESULTS OF VASCULAR ACCESS}

A proposal for standardised reporting on vascular access surgery has been put forth and has been tested in a concrete situation. Comparing reports on the results of access surgery has been difficult, because of a lack of consensus about minimum requirements in reporting results. A report on the results of vascular access surgery must present data on cumulative patency rates, including and excluding salvage procedures. Furthermore intervention free periods and life expectancy of shunts must be reported. Definitions of the various terms are given.

\section{EARLY FAILURE OF VASCULAR ACCESS}

We have defined early failure as failure within 4 days. A vascular access that is used for dialysis will always be examined within this period. Others have defined early failure of newly constructed $A \cdot V$ fistulas as failure within 4 weeks. It can be argued that 4 weeks is a reasonable period to decide whether an A-V fistula will function. Yet, it is an arbitrary choice because many fistulas need a longer time to ripen and may still be utilised. We analysed the time of failure of shunts and were able to prove, in our material, that a certain, steady percentage of A.V fistulas failed after an accelerated failure rate in the first few days. The early failure rate can be kept low when little risk is taken with regard to the quality of veins and arteries to be used for the shunt. But also the avoidance of technical pitfalls, learned through experience, will protect 
the access from early failure. The high early failure rate for surgical reinterventions in our study (27\%) may reflect a negative selection since, in the case-of stenoses, a PTA is attempted first; however, it also reflects the well-known problems of salvage in access surgery.

\section{CHANGES IN VASCULAR ACCESS PATTERNS}

During the last 10 years, the percentage of patients with an $\mathrm{A} . \mathrm{V}$ fistula of the forearm (Cimino), generally accepted as the first choice for vascular access, has not changed substantially. There has however, been a sig. nificant change in the frequency of use of other types of access. The Scribner shunt is used much less. Among the grafts, the use of PTFE and the homologous vein (Varivas ${ }^{*}$ ) is steadily increasing and the use of the autologous vein is decreasing.

\section{THE COSTS OF VASCULAR ACCESS SURGERY}

Cost analysis of vascular access for haemodialysis should be considered when making decisions involving the appropriate approach to the treatment of end stage renal disease. As expected, first choice access surgery is less expensive than second choice access surgery. Second choice access surgery tends to be more difficult, may require an expensive vascular graft and is associated with a longer stay in the hospital.

The evolution of the population in centres for dialysis in the Neth. erlands differs from one centre to the other. In general, the tendency towards the treatment of older patients and patients in poorer health will make the construction of vascular access more difficult in the future. In our studies, no calculations were made for the different age groups.

We determined that the patency rate for Cimino A $V$ fistulas increased by $7 \%$ in the first year and by $15 \%$ after 2 years with the use of PTA as a routine adjuvant procedure in the maintenance of fistula function [13]. The extra costs incurred in order to achieve this improvement in fistula function were Dfl 1380 (USD 775) per patient per year. While we conclude that routine application of PTA carries with it an extra cost of nearly Dfl 1400 , we must also bear in mind that if no simple new Cimino A-V fistula can be created, a second choice access will have to be constructed with a considerable increase in the costs.

Under the circumstances of acute need at the start of haemodialysis, the costs of the Scribner A-V shunt as a semipermanent shunt are fairly low. For use in complicated situations during haemodialysis, the shunt is helpful but the costs are relatively high when repeated PTA's are necessary to maintain its function. 
Since the PTFE graft A.V fistula is now probably the most popular second choice access procedure and may be the best according to the literature, with a good survival rate [14], its costs, though higher than any first choice access, can still be considered acceptable. The cheaper autologous saphenous vein graft fistula is not often constructed, mainly because of the limited availability of an adequate vein and of the good patency rates in the hands of some surgeons only.

The costs per patient per year for vascular access are about USD 3640 (Dfl 6500), or $7.9 \%$ of the costs of haemodialysis per year (USD 24 or Dfl 42 per dialysis).

The added costs of routine PTA as an adjuvant to maintain Cimino A.V fistulas are, on the average, USD 785 (DFL 1400) per patient per year. For these fistulas, PTA may mean a saving since an expensive second choice access is not needed or can be postponed.

With PTA as an adjuvant to second choice access surgery, something which results in an improvement in the quality of life of the patients, costs incurred are higher, up to $16 \%$ of the cost of haemodialysis. In a limited number of cases, a more costly, but safe and reliable, method to maintain vascular access would still appear to be acceptable.

\section{Acute access}

Central venous catheters provide a relatively easy and rapid vascular access. These catheters, however, can cause serious trouble. Complications of central venous catheters include subclavian vein thrombosis, stenosis and sepsis $[5,6]$. Recent reports show fewer complications with jugular vein catheters $[7,8]$. The Scribner shunt, as a means of acute access, needs to be reconsidered. It can be used when acute haemodialysis is indicated as a semi permanent first choice access. It should be placed distally in a leg to spare arm vessels for an A.V fistula. Dubious arterial circulation of the legs makes a Scribner shunt in a leg undesirable because a distal artery has to be sacrificed. A Scribner shunt, preferably the Ramirez variation without a subcutaneous bend, which allows easier treatment for thrombosis and access for transluminal angioplasty, can serve well for many months without any serious complication. Twardowski [10] foresees greater use of the transcutaneous vascular access, especially the intravenous catheters. Perhaps we may even see a revival of Scribner shunt varieties or better implantable transcutaneous vascular accesses.

\section{Percutaneous transluminal angioplasty}

The routine application of PTA in the treatment of stenoses and, hence, in the maintenance of vascular access influences the number of operations 
required, the primary and secondary survival of fistulas and shunts and the costs of vascular access.

The conditions that are necessary for a successful routine application of PTA have to be agreed upon, because they fall outside the normal routine. They demand that nephrologists, surgeons and dialysis staff adopt a special attitude and that radio-interventionalists and vascular access surgeons especially be readily available. These conditions also include the accurate and timely diagnosis of stenoses in a vascular access. The problem is that all A.V fistulas have stenoses and that the functionally relevant stenoses must be detected. Monitoring and reporting of the arterial and venous pressures during dialysis provide an opportunity for that detection [9]. In the case of poor dialysis parameters, dilatation without delay is essential, as are the proper technical skills and sufficient care during the intervention. That involves training of personnel and monitoring of results. The new technique of PTA is effective and inexpensive for the maintenance of Cimino A.V fistulas. Graft A V fistulas can also be treated well with PTA when stenoses occur.

\section{Surveillance of vascular access}

Prevention of complications starts with creating a shunt of the best possible quality. The right puncture technique of the shunt, avoidance of infection and careful compression after removing the needle or cannula from the shunt after dialysis comes next. And then an adequate surveillance of the shunt must lead to a timely intervention in case of a threat to good function.

A method to organise or improve surveillance is to record details of performance of the access during each dialysis on a special chart on which interventions on the shunt are noted also with a drawing of the actual configuration of the access (Appendix 1).

These studies give an insight in vascular access and its development. Comparing subsequent periods of course cannot provide scientific proof such as a randomised trial might offer. However, some conlusions can be drawn.

\section{CONCLUSIONS}

1. Vascular access surgery in the Netherlands is developing into a branch of general vascular surgery. Further development must be stimulated as is done by the Working group for Access surgery, which promotes training and research. 
2. The long term results of vascular access surgery in the Drechtsteden Ziekenhuis Dordrecht of the different types of vascular access are in short: Before the application of PTA a 2-year secondary cumulative patency of $65 \%$ autogenous distal A.V fistula, of $52 \%$ for the graft A.V fistula and of $37 \%$ for the Scribner shunt was noted. After routine application of PTA an increased survival of a 2 -year secondary cumulative patency of $80 \%$ for the autogenous distal A.V fistulas was found, which was not statistically significant. Less surgical interventions were needed. For graft fistulas no increased survival was noted, but less surgical interventions were required. The Scribner shunts were succesfully treated with PTA and needed far less surgical revisions. Their survival as a group could not be compared validly with an earlier period, because their use was limited for the majority of the patients, more so during the last ten years than before.

3. Since the distal autogenous Cimino A.V fistula is the first choice access, considerable efforts to establish such a fistula are justified. For patients who may have to be dialysed, attempts must be made to save the veins of at least one arm from puncture for diagnosis and intravenous infusions.

4. There may still be a valid place for the Scribner shunt, in the Ramirez variation with an external bend, as a safe and easy access since it is associated with few serious complications when constructed with great care and maintained with the help of PTA $[7,8]$.

5. Structured, disciplined monitoring of vascular access is more relevant when a relatively moderate intervention (PTA) can cure the problem. Monitoring must include regular measurement and evaluation of venous and arterial pressure, blood flow and clinical signs and symptoms. Timely interventions - medical, surgical or radio-interventional - not only save shunts but probably also greatly contribute to the welfare of the patient. This has to be investigated.

6. Routine application of PTA leads to less vascular surgery and good survival for shunts. The use of PTA has had a distinct impact on the number of surgical interventions indicated for the treatment of vascular stenosis in access surgery. A PTA increases the longevity of an internal shunt by 310 days ( 347 days excluding early failure). In the present study, an external shunt had an increased longevity of 54 days ( 59 days excluding early failure). 
7. PTA may be an improvement in the management of vascular access and it positively affects the quality of life for the patient. Such an intervention which can be performed on an out-patient basis or during a short hospital stay, is appreciated by patients much more than surgery.

8. A statistically significant increased survival for an entire group of shunts of a certain type, when PTA is routinely applied, has not yet been proven. It may very well be possible to demonstrate a significant increase in survival of vascular access for an entire group when more patients have been treated.

9. Complications of PTA, such as thrombosis or the rupture of a blood vessel, do occur but can be managed without serious problems because the bloodvessels are superficial. They are usually diagnosed immediately as angiography is part of the PTA procedure. Ruptures can often be treated conservatively.

10. The costs of vascular access for haemodialysis vary from $3.5 \%$ of the total costs of haemodialysis for the most simple access to $16 \%$ for the more complicated types of access. The extra costs for routine application of PTA for the first choice access are low. The increased survival of first choice access may even mean a netto saving. The costs for second choice access have been higher after application of PTA. Whether they are justified, as more difficult treatments can be avoided, should be the subject of further investigations.

\section{REFERENCES}

1. Reilly DT, Wood RFM, Bell PRF. Arteriovenous fistulas for dialysis: Blood Flow, Viscosity and long term patency. World J Surg 1982; 6: 628.633.

2. Reilly DT, Wood RFM, Bell PRF. Prospective study of dialysis fistulas: problem patients and their treatment. Br J Surg 1982; 69: 549-53.

3. Müller-Wieffel H, Haug M. Zur Frage des geeigneten Gefassersatzes in der Dialyse Shunt Chirurgie. Angio 1983; 5: 199-209.

4. Eikelboom $\mathrm{BC}$. What material should be used in secondary haemodialysis access surgery. Eur J Vasc Surg 1988; 2:1-2.

5. Staal RP, Brom HLF. Homologous venous grafts for access surgery. In: Progress in surgery. Tordoir JHM, Kitslaar PJEHM, Kootstra G. eds. Datawyse, Maastricht, 1990: 22.25.

6. Andersen JT, Gammelgaard J, Nielsen LM. Subclavian vein catheterization for acute and chronic haemodialysis. A safe temporary vascular access. Int Urol Nephr 1986; 18: 327-332. 
7. Vanherweghem JL, Yassine T, Goldman M, Vandenbosch G, Delcour C, Struyven J, Kinnaert P. Subclavian vein thrombosis: a frequent complication of subclavian vein cannulation for haemodialysis. Clin Neph 1986; 25: 235.238.

8. Tesio F. A two catheter internal jugular vein cannulation: For long-term vascular access for hemodialysis. 38th Annual ASAIO Meeting, 1992, Nashville, TN, USA.

9. Blanchier D, Pengloan J, Turmel-Rodriques L, Haillot O. Pressure monitoring during dialysis session and early detection of vascular access stenoses by angiography. In: Progress in access surgery. Tordoir JHM, Kitslaar PJEHM, Kootstra G eds. Datawyse, Maastricht, 1990: 141-144.

10. Twardowski ZJ. How will chronic dialysis change over the next decade?' Seminars in Dialysis 1991; $4: 231-232$. 


\section{CHAPTER 7}

\section{SUMMARY}

In this thesis vascular access for haemodialysis is investigated. Fifty years ago the first successful haemodialysis was carried out by Kolff at Kampen in the Netherlands. After twelve dialyses in nearly six weeks this treatment had to be terminated because of a lack of vascular access.

Only in 1960 Quinton, Scribner and associates succeeded in constructing a permanent vascular access, the arteriovenous (A.V) shunt. From that time onwards a growing number of patients, now hundreds of thousands around the world, can live with the help of an artificial kidney. Some years later Brescia, Cimino and associates succeeded in constructing a better vascular access, an A-V fistula. By such a fistula the superficial veins are filled with arterial blood. In this way the opportunity is given to let many litres of blood pass through the artificial kidney by puncturing the arterialised veins.

Apart from haemodialysis, two other treatment modalities are available for end stage renal disease, continuous ambulant peritoneal dialysis (CAPD) and renal transplantation, the most desirable treatment.

The aims of this thesis were:

1. To establish the state of vascular access for haemodialysis in the Netherlands.

2. To investigate the long term results of the different types of vascular access and the effect of percutaneous transluminal angioplasty (PTA) on the results.

3. To investigate the effects of the routine application of PTA for treatment of stenotic complications in vascular access on the number of surgical interventions needed to maintain an adequate vascular access for haemodialysis.

4. To investigate the costs of vascular access surgery and PTA and the effects of routine application of PTA on the total costs of vascular access. 
In Chapter 1 a survey of the more recent general literature on vascular access for haemodialysis is given and the Dutch theses on the subject are mentioned. A few historical remarks are made. Quinton, Scribner and associates succeeded in 1960 to construct a permanent vascular access that functioned well. From that year onward chronic haemodialysis was possible. The vascular anastomosis already pioneered by Carrel in the beginning of the century proved effective in providing a ready vascular access.

Vascular access surgery has developed from modest beginnings to a subspeciality, because a wide range of possibilities to gain and maintain vascular access are available.

Foremost is the A.V fistula developed in 1966 by Brescia, Cimino and associates. This vascular access is still the most effective because of its lower rate of complications and longer overall survival.

Reviewing the most available possibilities for a vascular access also are mentioned the proximal A.V fistula, the graft fistula and implantable systems. A number of graft materials, biological grafts and allografts have been tested. Some, especially the homologous vein graft give good results, but over the last years there is a clear preference for expanded polytetrafluoroethylene (PTFE).

The importance of a good surveillance of the vascular access for early detection of complications is stressed. The diagnostic methods, invasive (angiography) and non invasive (duplex scanning) play a role. The complications of vascular access, thrombosis, stenosis and infection and a number of less frequent ones with emphasis on their treatment is given.

Acute vascular access demands immediate usability and a different approach. While at first the AV shunt (Scribner) was the self evident choice, central venous catheters became a much easier and also preferred solution because no vessels had to be sacrificed, or so it seemed. However, the complications of central venous catheters, especially subclavian vein thrombosis, can obviate an access in the same arm. Jugular vein catheterization may turn out to be superior to the use of the subclavian vein.

The introduction is concluded by calling attention to the emergence of percutaneous transluminal angioplasty (PTA) for vascular access. The technique of dilating stenoses in bloodvessels called transluminal angioplasty or Dotter technique after its originator Dotter, has been quite useful for the treatment of stenoses in vascular access. It can often be carried out percutaneously, i.e., without an operation. Over the last seven years experience has been obtained in Dordrecht with routine application 
of PTA for all stenoses in vascular access. In this study on vascular access the effects of this method are analysed.

In Chapter 2 the results are offered of a survey of vascular access for haemodialysis in the Netherlands. On 1 January 1988, 2195 patient in 52 centres were on long term haemodialysis and 588 on CAPD. Of all the patients on haemodialysis $70 \%$ had a Cimino fistula, $22 \%$ a graft fistula, $6 \%$ a proximal arm fistula and $2 \%$ had a Scribner shunt. As graft material 58\% had a PTFE graft, 25\% homologous vein graft, $13 \%$ a autologous vein graft and $4 \%$ a graft of other materials.

For acute access $46 \%$ of the centres positively preferred the subclavian vein catheter, $33 \%$ preferred femoral vein catheters. The Scribner shunt was applied only in selected cases in $22 \%$ of the centres.

In 1987 routine use of PTA was limited to a few centres.

In Chapter 3 the effects of PTA on longevity of fistulas and shunts for haemodialysis and the number of surgical interventions needed to maintain vascular access are described. During three years PTA was applied 94 times in a haemodialysis population of about 50 patients. A reduction of surgical reinterventions of $30 \%$ was achieved, as compared to the three preceding years. There was a $50 \%$ reduction in surgical interventions with stenosis as indication. Longevity of A.V shunts was increased with 2 months and of A.V fistulas with 1 year for every PTA.

In Chapter 4 a standard for assessing functional patency of vascular access is formulated and long term results of vascular access in a dialysis population, in particular the effects of PTA are presented. Primary and secondary patency of an access, as well as intervention-fiee periods are reported. The life expectancy of a group of A-V shunts or fistulas is assumed to be equivalent to the median secondary survival.

During a period of 20 years $407 \mathrm{~A} \cdot \mathrm{V}$ fistulas and shunts were constructed for 259 patients on chronic haemodialysis. In total 1179 interventions were performed, including 519 surgical reinterventions and 253 PTA's. The overall secondary cumulative patency rate for the autogenous distal A-V fistulas (Cimino) was $79 \%$ for one year, $68 \%$ for two years and $59 \%$ for three years. Routine application of PTA from 1986 onward resulted in a rise of secondary cumulative patency for Cimino A.V fistulas after two years from $65 \%$ in the $1980-1985$ period till to $80 \%$ in the 1985 1991 period. 


\section{Chapter 7}

In Chapter $\mathbf{5}$ a cost analysis of vascular access for haemodialysis is presented. The costs of haemodialysis make up a considerable part of renal replacement therapy. These costs amounted to DFL 106000 reimbursable costs and to DFL 81000 full costs. Calculation of the costs of access surgery, as well as the costs for special interventions per patient per year, has been carried out.

As PTA has increasingly become a useful adjuvant in the treatment of stenoses in vascular access comparing of the costs before and after application of was done. Two periods: 1980-1985 and 1986-1991 were contrasted. The higher quality of life that results when PTA is routinely used, carries with it added costs, especially for secondary access procedures. Overall costs per patient per year for creating and maintaining vascular access, surgery and PTA were about Dfl $6500^{\circ}$, or $7.9 \%$ of the costs of haemodialysis during the period 1986-1991. For Cimino A.V fistulas these costs amounted to Dfl 2850 per patient per year. Yet for Dfl 1400 extra per patient per year, the Cimino A.V fistula had a prolonged survival of the access of $7 \%$ in the first year and $15 \%$ in the second year when PTA was used as an adjuvant to surgery. PTA increases the costs of access surgery to a modest extent, while clearly improving the patients quality of life.

In Chapter 6 the investigations are discussed and conclusions are reached. Attention is paid to the fact that these studies provide no scientific proof but that an insight in vascular access is provided. 


\section{SAMENVATTING}

In dit proefschrift wordt de toegang tot de bloedbaan voor hemodialyse onderzocht. Vijftig jaar geleden werd de eerste geslaagde hemodialyse uitgevoerd in Nederland te Kampen door Kolff. Na twaalf dialyses in bijna zes weken moest deze behandeling worden beẽindigd bij gebrek aan een goede toegang tot de bloedbaan.

Pas in 1960 gelukte het Quinton, Scribner c.s. een voor een langere tijd bruikbare toegang tot de bloedbaan te maken, de arterioveneuze shunt. Vanaf die tijd kan een groeiend aantal patiēnten, nu honderd. duizenden over de gehele wereld, leven met hulp van een kunstnier. Enkele jaren later, in 1967 gelukte het Brescia en Cimino c.s. een betere toegang tot de bloedbaan te maken in de vorm van een arterio-veneuze fistel bij de pols. Door deze fistel worden de oppervlakkige aderen met arteriëel bloed gevuld, hetgeen de mogelijkheid geeft meer malen per week d.m.v. venepunctie van de geärterializeerde venen vele liters bloed door de kunstnier te laten stromen.

Naast hemodialyse bestaan er nog twee behandelingswijzen voor ernstige nierinsufficiëntie: peritoneaal dialyse en de meest gewenste behandeling, niertransplantatie.

De doelen van dit proefschrift zijn:

1. Vaststelling van de toestand van de vasculaire toegangschirurgie in Nederland.

2. Onderzoek van de lange termijn resultaten van de verschillende types van vasculaire toegang en het effect van percutane transluminale angioplastiek (PTA) op de resultaten.

3. Onderzoek van de effecten van routinematige toepassing van PTA op de behandeling van stenoses (vernauwingen) in vasculaire toegangen op het aantal chirurgische ingrepen, dat nodig is voor het onderhouden van adequate vasculaire toegang voor hemodialyse.

4. Onderzoek van de kosten van vasculaire toegangschirurgie en PTA en de effecten van routinematige toepassing van PTA op de totale kosten van vasculaire toegangen. 
In Hoofdstuk 1 wordt een overzicht van de meer recente literatuur over toegang tot de bloedbaan gegeven en de Nederlandse proefschriften over dit onderwerp worden genoemd. Enkele historische opmerkingen worden gemaakt. Quinton, Scribner en medewerkers gelukte het in 1960 een toegang tot de bloedbaan te maken, die goed functioneerde. Vanaf die tijd was chronische dialyse mogelijk. De A.V anastomose waarvoor het pionierswerk al in het begin van de eeuw door Carrel werd verricht, bleek effectief om een goed bruikbare toegang tot de bloedbaan te verkrijgen.

Van groot belang is de A.V fistel in 1966 ontwikkeld door Brescia, Cimino en medewerkers. Deze toegang tot de bloedbaan is nog steeds de meest effectieve, omdat hij het laagste aantal complicaties heeft en de langste levensduur. De meeste beschikbare toegangen tot de bloedbaan overziend worden ook genoemd de proximale A.V fistel, de transplantaat A.V fistel en de implanteerbare systemen. Gedurende de laatste jaren is er een duidelijke voorkeur voor geëxpandeerde polytetrafluoroethyleen (PTFE) transplantaten, maar sommige andere transplantaten, speciaal de homologe venetransplantaten geven ook goede resultaten.

Het belang van een goed bewaking van toegangen tot de bloedbaan om complicaties vroeg te kunnen ontdekken wordt benadrukt. De diagnostische methoden, de invasieve (angiografie) en de niet invasieve (duplex scanning) spelen een belangrijke rol. De complicaties van toegangen tot de bloedbaan, thrombose, stenose en infectie en een aantal minder frequente complicaties met een nadruk op hun behandeling wordt gegeven.

Acute toegang tot de bloedbaan vraagt onmiddellijke bruikbaarheid en een andere benadering. Terwijl aanvankelijk de A-V shunt (Scribner) de vanzelf sprekende keuze was, werden later centraal veneuze catheters de eerste keus, angezien geen vaten hoefden te worden opgeofierd, tenminste dat leek zo. Echter, de complicaties van centraal-veneuze catheters, speciaal thrombose van de vena subclavia, kunnen een toegang tot de bloedbaan in de betreffende arm onmogelijk maken. Catheterisatie van de vena jugularis lijkt beter te zijn dan het gebruik van de vena subclavia.

Tenslotre wordt de introductie besloten met een bijzondere aandacht voor de percutane transluminale angioplastiek (PTA) voor toegang tot de bloedbaan. De techniek van het verwijden van stenoses (vernauwingen) in bloedvaten, ook wel dotteren genoemd naar de initiator Dotter, is gebleken een zeer bruikbare behandeling te zijn bij stenoses in A. $\mathrm{V}$ fistels en shunts. De methode kan vaak worden uitgevoerd d.m.v. een punctie van een shunt bloedvat, d.w.z. zonder operatie. Gedurende de 
laatste zeven jaar is te Dordrecht veel ervaring opgedaan met de routinematige toepassing van PTA voor alle stenosen in toegangen tot de bloedbaan. In dit proefschrift worden de effecten van deze methode geanalyseerd.

In Hoofdstuk 2 worden de resultaten van een gegeven van een overzicht van toegang tot de bloedbaan voor hemodialyse in Nederland. Op 1 januari 1988, waren 2195 patienten in 52 centra in chronische hemodialyse en 588 werden met CAPD behandeld. Van alle patiēnten in hemodialyse had $70 \%$ een Cimino fistel, $22 \%$ een transplantaat fistel, $6 \%$ een proximale A.V fistel in de arm en $2 \%$ een Scribner shunt. Als transplantatie materiaal had $58 \%$ een PTFE transplantaat, $25 \%$ een homoloog vene transplantaat, $13 \%$ een autoloog venetransplantaat.

Voor acute toegang prefereerde $46 \%$ van de centra duidelijk de $v$. subclavia catheter, $33 \%$ prefereerde de v. femoralis catheter. De Scribner A.V shunt werd slechts toegepast in geselecteerde gevallen in $21 \%$ van de centra. In 1987 was het routinegewijs toepassen van PTA beperkt tot slecht enkele centra.

In Hoofdstuk 3 worden de effecten beschreven van PTA op de levensduur van. fistels en shunts en het aantal chirurgische ingrepen nodig om de toegang tot de bloedbaan in stand te houden. PTA werd in een periode van drie jaar 94 keer toegepast in een groep van 50 hemodialyse patiënten. Er werd een afname van chirurgische ingrepen van $30 \%$ gezien, vergeleken met de drie voorafgaande jaren. De chirurgische ingrepen met stenose als indicatie namen af met $50 \%$. De levensduur van A.V shunts nam gemiddeld toe met twee maanden en die van $\mathrm{A} \cdot \mathrm{V}$ fistels met één jaar na elke PTA.

In Hoofdstuk 4 wordt de levensduur van A.V fistels en shunts voor hemodialyse behandeld en de behoefte aan gestandariseerde rapportage van de resultaten. Primaire en secundaire functionele (bruikbare) doorgankelijkheid van een toegang, zowel als de interventie-vrije perioden moeten worden gerapporteerd. De levensverwachting van een groep A-V shunts of fistels wordt geacht equivalent te zijn aan hun mediane secundaire overleving.

Gedurende een periode van 20 jaar, van 1971 tot 1991, werden voor 259 patiënten in chronische hemodialyse $407 \mathrm{~A} \cdot \mathrm{V}$ fistels en shunts aangelegd. In totaal werden 1179 interventies uitgevoerd, waaronder 519 chirurgische reinterventies en 253 PTAs. De cumulatieve doorgankelijkheid voor de gehele periode voor de autogene distale A.V fistels (Cimino) 
was $79 \%$ na één jaar, $68 \%$ na twee jaar en $59 \%$ na drie jaar. Routine toepassing van PTA vanaf 1986 resulteerde in een stijging van de secundaire cumulatieve functionele doorgankelijkheid van Cimino A-V fistels na twee jaar van $65 \%$ in de periode $1980-1985$ tot $80 \%$ in de periode 1986-1991.

În Hoofdstuk 5 wordt een kostenanalyse van vasculaire toegangschirurgie in het Drechtsteden Ziekenhuis beschreven. De kosten van hemodialyse zijn een aanzienlijk deel van niervervangingstherapie. Deze kosten bedroegen in 1988 ongeveer FI 106000 in declarabele kosten en Fl 81000 in werkelijke kosten per patiënt per jaar. De kosten van vasculaire toegangschirurgie in Nederland zijn tot nu toe niet uitgerekend of althans niet gepubliceerd. Berekening van deze kosten, zowel als de kosten voor de verschillende interventies per patiënt per jaar zijn uitgevoerd.

Aangezien PTA in toenemende mate een bruikbare methode is geweest voor de behandeling van stenoses van toegangen tot de bloedbaan is een vergelijkend onderzoek gedaan naar de kosten voor en na toepassing van PTA. Twee perioden: 1980-1985 en 1986-1991 werden tegenover elkaar gezet. De hogere kwaliteit van leven die resulteert als PTA routinematig wordt toegepast geeft hogere kosten, speciaal voor secundaire toegangs procedures. De globale kosten per patiënt per jaar voor het maken en onderhouden van een toegang tot de bloedbaan, chirurgie en PTA, waren ongeveer Fl 6500 , of $7,9 \%$ van de kosten van hemodialyse gedurende de periode 1986-1991. Voor de Cimino A-V fistel bedroegen deze kosten Fl 2850 per patiënt per jaar. Voor Fl 1400 extra per patiënt per jaar hadden de Cimino A.V fistels een toegenomen levensduur van $7 \%$ in het eerste jaar en $15 \%$ in het tweede jaar, toen PTA als steun bij het onderhoud van de vasculaire toegang werd gebruikt. PTA doet de kosten van vasculaire toegangschirurgie matig toenemen, terwijl het de kwaliteit van leven van de patiënten verbetert.

In Hoofdstuk 6 worden de onderzoeken besproken en worden conclusies getrokken. Deze onderzoeken geven een inzicht in de vasculaire toegangschirurgie. De vergelijking van opvolgende periodes levert natuurlijk geen wetenschappelijk bewijs, zoals een "randomised trial" zou leveren. Echter enige conclusies kunnen worden getrokken:

1. Vasculaire toegangschirurgie in Nederland ontwikkelt zich tot een tak van algemene vaatchirurgie. Verdere ontwikkeling moet worden gestimuleerd zoals wordt gedaan door de Werkgroep voor Toegangschirurgie, die training en onderzoek bevordert. 
2. De lange-termijn resultaten van chirurgie voor de toegang tot de bloedbaan zijn in het kort de volgende: Vór de toepassing van PTA een 2-jaars secundaire "patency" van $65 \%$ voor de autogene distale A.V fistel, van $52 \%$ voor de transplantaat A.V fistel en van $37 \%$ voor de Scribner shunt.

$\mathrm{Na}$ routine toepassing van PTA was er een toename van de cumulatieve secundaire "patency" tot $80 \%$ voor de Cimino A.V fistel, welke toename toch niet significant was. Minder chirurgische ingrepen waren nodig. Voor transplantaat A. V fistels werd geen toegenomen "patency" opgemerkt, maar minder chirurgische ingrepen waren nodig. De Scribner shunts werden met succes behandeld met PTA en hadden veel minder chirurgische ingrepen nodig. Hun overleving als groep kon niet zinvol worden vergeleken met een eerdere periode, omdat hun toepassing beperkt was voor de meeste patienten, in de laatste tien jaar nog meer dan vroeger.

3. Omdat de distale autogene Cimino A.V fistel de eerste keus voor toegang tot de bloedbaan voor hemodialyse is, zijn aanzienlijke inspanningen gerechtvaardigd om te zorgen dat zo'n fistel gemaakt wordt. Het sparen van de venen van tenminste één arm met vermijden van diagnostische puncties en intraveneuze infusen moet nadrukkelijk worden nagestreefd voor patiënten die mogelijk zullen moeten worden gedialyseerd.

4. Er is waarschijnlijk nog steeds een nuttige plaats voor de Scribner shunt, in de Ramirez variatie met uitwendige bocht, als een veilige en relatief gemakkelijke toegang tot de bloedbaan met zeer weinig ernstige complicaties, wanneer hij gemaakt wordt met grote zorg. Waneer de stenoses bij de vaattip worden behandeld met PTA kan het aantal operatieve interventies om de shunt in stand te houden laag z.ijn.

5. Een gestructureerde gedisciplineerde controle van vasculaire toegangen is nog zinvoller nu een relatief lichte ingreep het probleem van stenosering mogelijk kan oplossen. De controle moet mede inhouden regelmatige meting van de veneuze drukken en de bloedstroom en beoordeling van de klinische verschijnselen en symptomen. De controle spaart niet alleen shunts door tijdige nefrologische, chirurgische of radio interventionele ingrepen, maar hij draagt waarschijnlijk in hoge mate bij aan het welbevinden van de patiënt. Dit moet nader onderzocht worden.

6. Routinematige toepassing van PTA leidt tot minder vaatoperaties en een waarschijnlijk verhoogde secundaire overleving van A.V fistels en shunts. Gemiddeld geeft een PTA een toename van de overleving 
van een inwendige shunt van 310 dagen ( 347 dagen excl. vroege mislukking). Voor de uitwendige shunt werd een toegenomen levensduur van 5.4 dagen ( 59 dagen excl. vroege mislukking) gevonden.

7. PTA kan een verbetering zijn bij het beheer van de toegangen tot de bloedbaan en beĭnvloed $t$ de kwaliteit van leven positief. Een poliklinische interventie of één met een opname van een dag wordt door de patiënten bijna altijd verkozen boven een chirurgische ingreep.

8. Een statistisch significant toegenomen levensduur voor de hele groep van shunts van enig type, als PTA routinematig wordt toegepast, is nog niet bewezen. Het zou heel wel mogelijk kunnen zijn een dergelijk significante toename aan te tonen, als meer patiënten behandeld zijn.

9. Complicaties van PTA, zoals thrombose en ruptuur van een bloedvat komen voor maar kunnen relatief gemakkelijk behandeld worden omdat de vaten oppervlakkig liggen. Zij worden gewoonlijk onmiddellijk ontdekt omdat angiografie deel van de PTA procedure is. Een ruptuur kan meestal conservatief worden behandeld.

10. De kosten van een toegang tot de bloedbaan variëren van $3,5 \%$ van de totale kosten voor hemodialyse voor de eenvoudigste toegang tot $16 \%$ van de totale kosten voor de meer gecompliceerde soorten toegangen. De extra kosten voor routine toepassing van PTA voor de eerste keus toegang zijn laag. De toegenomen levensduur van eerste keus toegangen zou zelfs een netto besparing kunnen betekenen. De kosten van tweede keus toegangschirurgie zijn hoger geworden na toepassing van PTA. Of deze kosten gerechtvaardigd zijn, omdat moeilijker behandelingen kunnen worden vermeden zou nader onderzocht moeten worden. 


\section{LITERATURE}

Alwall N, Norvit L, Steins AM. On the artificial kidney VII. Acta Med Scand $1949 ; 132: 589.602$.

Aman LC, Sмттн. DW, Oн HK, Levin NW. Vascular access survival in diabetic and non-diabetic haemodialysis patients. In: Kootstra G, Jorning PJG, eds Access Surgery, Proceedings of the International Congress on Access Surgery. Lancaster: M.T.P. Press, 1983: 179-190.

Andersen JT, Gammelgando J, Nielsen LM. Subclavian vein catheterization for acute and chronic haemodialysis. A safe temporary vascular access. Int Urol Nephr 1986; 18: 327.332.

Anderson CB, Jendrisak MJ. Complications of prosthetic arteriovenous fistulas. In: Progress in Access Surgery. Tordojr JHM, Kitslaar PJEHM, Kootstra G eds. Maastricht: Datawyse, 1990: 58-65.

Anderson CB, Gilula LA, Harter HR, Etheredge EE. Venous angiography and the surgical management of subcutaneous hemodialysis fistulas. Ann Surg 1977; 187: 194-204.

Armitage. P, Berry G. Statistical methods in medical research. 2nd ed. Oxford: Blackwell Scientific Publications, 1987: 421-38.

Baltard JL, Bunt TJ, Malone JM. Major complications of angioaccess surgery. Am J Surg 1992; 164: 229-232.

Bambauer R, Jutzler. GA. Transcutaneous insertion of the Shaldon catheter through the internal jugular vein as access for acute hemodialysis. Dial Transplant 1982; 11: 766 773 .

Bast TJ. De toegang tot de bloedbaan voor geregelde dialyse behandeling. [Dissertation]. Amsterdam, 1974. 
Bel. DD, Rosenthas. JJ. Arteriovenous graft life in chronic hemodialysis. Arch Surg 1988; 123: 1169-1172.

BeLL PRF, Vertch PS. Vascular access for hemodialysis. In: Clinical dialysis. Nissenson AR, Fine RN, Gentile DE eds. London: Prentice Hall, 1990: 26.44.

Beu. PRF, Calman KC. Surgical aspects of hemodialysis. Edinburgh: Churchill Livingstone, 1974.

Berne TV, Turner A, Barbour BH. Angiographic evaluation of QuintonScribner shunt malfunction. Surgery $1971 ; 69: 588-594$.

Blanchier D, Pengloan J, Turmel Rodriques L, hallot O. Pressure monitoring during dialysis session and early detection of vascular access stenoses by angiography. In: Progress in access surgery. Tordoir JHM, Kitslaar PJEHM, Kootstra G eds. Maastricht: Datawyse, 1990: 141-144.

Boen ST, Mion CM, Curtis FK, Shilipetar G. Periodic peritoneal dialysis using the repeated puncture technique and an automatic cycling machine. Trans Am Soc Artif Intern Organs 1964; 10: 409.

Bonalumi U, Civalleri D, Rovida S, Adami GF, Giannetta E, Griffantr. Bartoli F. Nine years experience with end-to-end arteriovenous fistula at the 'anatomical snuffbox' for maintenance haemodialysis. Br J Surg 1982; 69: $486 \cdot 488$.

Bonnaud Ph, Man NK. Ten years experience on 310 homologous vein grafts for arteriovenous fistula. In: Access Surgery, Kootstra G, Jorning PJG eds. Lancaster: MTP Press Lid, 1983: 117.

Boomsma JH, Beukhof JR, Geerl.ings W. Intravenous digital subtraction angiography of arteriovenous fistulas and shunts for hemodialysis. Diagn Imag Clin Med 1984; 22: 258261.

Brescia MJ, Cimino JF, Appel K, Hurwich JB. Chronic Hemodialysis using venipuncture and a surgically created arteriovenous fistula. New Eng J Med 1966; 275: 1089-1092. 
Brooks JL, SigLEy RD, MAY KJ, MACK RM. Transluminal angioplasty versus surgical repair for stenosis of hemodialysis grafts. Am J Surg 1987; 153: 530-531.

Broyer M, Brunner FP, Brynger H, Fassbinder W, Gullou PJ, Oules $\mathbb{R}$. EDTA Registry Centre Survey, 1985. Nephrol Dial Transplant 1987; 2: 475-487.

Burger H, Kunchert SA, Kootstra G, Krtslanr PJEHM, Ubink DTh. Survival of arteriovenous fistulas and shunts for haemodialysis. Eur J Surg 1994; in press.

Burger H, Zulstra J, Kunchert SA, KoOtstra G. Long-term results of routine application of percutaneous transluminal angioplasty as an adjuvant to access surgery. in: Progress in access surgery. Tordoir JHM, Kitslaar PJEHM, Kootstra G eds. Maastricht: Datawyse, 1990: 165-170.

Burger H, Kootstra G, de Charro F, Lefrers P. A survey of vascular access in The Netherlands. Nephrol Dial Transpl 1991; 6: 5-10.

Burger H, Zulstra JJ, Kunchert SA, Scholten AP. Percutaneous transluminal angioplasty improves longevity in fistulae and shunts for haemodialysis. Nephrol Dial Transplant 1990; 5: 608-611.

Cada E, Karnei. F, Mayer G, Langle F, Scurawtizki H, Graf H. Pefcutaneous: transluminal angioplasty of failing arteriovenous dialysis fistulae. Nephrol Dial Transplant 1989; 4: 57-61.

Canaud B, Beraud J, Joyeux H, Mion C. Internal jugular vein cannulation using two silastic catheters. Nephron 1986; 43: 133-138.

Canaud B, Cristol JP, Klouche K, Béraud JJ, Mion C. Silastic twiñ catheters: A flexible solution for temporary or long-term vascular access problems: in hemodialysis patients. In: Blood Purification in perspective. Man NK, Botella J, Zuchelli P. eds. Cleveland: ICAOT Press, 1992: 25-29.

CARREl A. La technigue opératoire des anastomoses vasculaires et les transplantations des viscères. Lyon Med 1902; 98: 859.

Carrel. A, Guthrie CC. Functions of a transplanted kidney. Science 1905; 22: 473 . 


\section{Literature}

Chapman JE, Sinicrope RA, Ciark DM. Angio and peritoneal access for endstage renal disease in the community hospital: a cost analysis. Am Surg 1986; 52: 315-319.

Charro DE FTH. [Cost-effectiveness analysis of the end stage renal disease program in The Netherlands] [Dissertation]. Rotterdam, 1988.

Clark DD, Albina JE, Chazan JA. Subclavian vein stenosis and thrombosis: a potential serious complication in chronic hemodialysis patients. Am J Kidney Dis 1990; 15: 265-268.

Coluns AJ, Shapiro Fl, Keshavia P, Ilstrup K, Andersen R, O'Brien T, Cosinto LC. Multicentre clinical experience with the Hemasite blood access device. In: Access Surgery Kootstra G, Jorning PJG eds. Lancaster: MTP Press Ltd, 1983: 297-301.

Croxson BE, Ashron T. A cost effectiveness analysis of the treatment of end stage renal failure. N Z Med J 1990; 103: 171.174.

Dapunt O, Feurstein M, Rfndi KH, Prenner K. Transluminal angioplasty versus conventional operation in the treatment of haemodialysis fistula stenosis: Results from a 5-year study. Br J Surg 1987; 74: 1004-1005.

Davis GB, Dowd CF, Maroney TP, Lang EV, Halasz N. Thrombosed Dialysis Grafts: Efficacy of intrathrombic deposition of concentrated urokinase, clot maceration, and angioplasty. AJR 1987; 149: 177-181.

DOTTER CT, Judkins MP. Transluminal treatment of arteriosclerotic obstruction: Description of a new technique and a preliminary report of its application. Circulation 1964; 30: 654-670.

Dupuy CA, Cavilion C, Houlgatte: A, Mouton A, Angot M, Bourquelot P. Major proximal vein obstruction coexisting with angioaccess for chronic haemodialysis. In: Tordoir JHM, Kitslaar PJEHM, Kootstra G, eds. Progress in Access Surgery. Maastricht: Datawyse, 1990, 88.92.

EDTa (European Dlalysis and Transplantation Assoclation) Report: 1978, 53-6. 
EFfeney DJ, Stoney RJ. Acute and chronic access to the circulation. In Wylie's atlas of vascular surgery, volume VI. Philadelphia: J.B. Lippincott Comp., 1993: 72-113.

Eıкецвоом BC. What material should be used in secondary haemodialysis access surgery. Eur J Vasc Surg 1988; 2: 1.2.

Erben J, Kvasnicka J, Bastecky J, Vortel V. Experience with routine use of subclavian vein cannulation in haemodialysis. Proc Eur Dial Transplant Assoc 1969; 6: 59-64.

Fernando ON. Arteriovenous fistulas by direct anastomosis. In: Vascular Access Surgery, Wilson SE ed. 2nd ed., Chicago: Yearbook Medical Publishers Inc., 1988: 197-212.

FrANKL. WS. A comparison of coronary artery bypass surgery and percutaneous transluminal angioplasty in the treatment of coronary artery disease, part 2. Modern Concepts Cardiovasc Dis 1990; 59: 37-42.

Gaux JC, Bourquelot P, Guidet B, Seurot M, Raynaud A, Blanchard D. Short-term follow-up of percutaneous transluminal angioplasty of ste noses located on fistulas used for haemodialysis. In: Kootstra $G$, Jorning PJG eds. Access Surgery. Lancaster: M.T.P. Press, 1983: 223.

Glanz S, Gordon D, Butt K, Hong J, Lipkowtrz G. The role of percutaneous angioplasty in the management of chronic hemodialysis fistulas. Ann Surg 1987; 206: $777-781$.

GMelin E, Wintherhoff R, Rinast E. Insufficient Hemodialysis access fistulas: late results of treatment with percutaneous balloon angioplasty. Radiology 1989; 171: 657-660.

Gordon DH, Gianz S, Butt KM, Adamsons RJ, Koenig MA. Treatment of stenotic lesions in dialysis access fistulas and shunts by transluminal angioplasty. Radiology 1982; 143: 53.58.

Gracz KC, Ing TS, Soung LS, Armbruster KF, Seim SK, Merkel. FK.

Proximal forearm fistula for maintenance hemodialysis. Kidney Int 1977; 11: 71-75. 
Gróntzig A, Hopff H. Perkutane Rekanalisation chronische arterielle Verschlusse mit einem neuen Dilatationskatheter. Modifikation der Dotter Technik. Dtsch Med Wochenschr 1974; 99: 2502-2505.

Haimov M, JAcoBson JH. Experience with modified bovine arterial heterografting peripheral vascular reconstruction and vascular access for hemodialysis. Ann Surg 1974; 180: 291-295.

Haimov M. The peripheral subcutaneous arteriovenous fistula. In: Haimov M, ed. Vascular Access. New York: Futura Publishing Company 1987: 41.58.

Haimov M ed. Vascular Access, a Practical Guide. New York: Futura Publishing Company, 1987.

Hylander B, Fernstróm A, Swedenborg J. Interposition graft fistulas for hemodialysis. Acta Chir Scand 1988; 154: 107-110.

Ishihara AM, Myers CH. Longevity of arterio-venous shunts for hemodialysis, Ann Surg 1968; 168: 281.286.

JONES KR. Factors associated with hospitalization in a sample of chronic hemodialysis patients. Health Serv Res 1991; 26: 671-699.

Kahn D, Pontin aR, Jacobson Je, Mathey P, Beningfield S, van Zijl-Smit R. Arteriovenous fistula in the presence of subclavian vein thrombosis: a serious complication. Brit J Surg 1990; 77: 682.

Kinnafrt P, Morus C. Arteriovenous fistula at the elbow for maintenance haemodialysis. In Access Surgery, Kootstra G, Jorning PJG eds. Lancaster: MTP Press Lid, 1983: 25-29.

Kuchert SA. Vena axillaris-obstructie [Dissertation]. Leiden, 1982.

KoLfF W]. De kunstmatige nier [Dissertation]. Kampen: Kok, 1946.

KolfF WJ, Berk HTJ, Welue ter M, LeY van der AJW, Dujk van EC, NoordWuK van J. De Kunstmatige nier. Een dialysator met groot oppervlak. Ned Tijdschr Geneeskd 1943; 87: 1684-1688. 
Kolff WJ, Berk HTJ, Weue ter M, Ley van der AJW, Duk van EC, Noordwuk van J. The artificial kidney: a dialyser with a great area. Acta Med Scand 1944; 67: 122-134.

KolfF WJ, Berk HTJ, Weue ter M, Ley van der AJW, Duk van EC, Noordwuk vaN J. De kunstmatige nier: een dialysator met groot oppervlak. Geneesk Gids 1943; 21 : 409-421.

Kootstru G, Jorning PJG, eds. Access Surgery, Proceedings of the International Congress on Access Surgery, Maastricht 1982. Lancaster: MTP Press, 1983.

Kоотsтra G. Quality-of-life assessment in end-stage renal disease. Theor Surg 1992; 7: 24:26.

Kоoтstra G. Secondary procedures for A.V fistula failure. Proc Eur Dial Transplant Assoc 1982; 19: 99-105.

Landmann J. Die arterio-venöse fistel für die chronische Haemodialyse. Helv Chir Acta 1987; 54: 603-610.

Lawrence PF, Miluer FJ and Mineau DE. Balloon catheter dilatation in patients with failing arteriovenous fistulas. Surgery 1981; 89: 439.442.

LINDBLAD A, NOVAK JW, NOLPH KD eds. Continuous ambulatory peritoneal dialysis in the USA - Final report of the National CAPD Registry 1981. 1988. Dordrecht: Kluwer, 1989.

Macdougall IC, Davies ME, Hallett I, Cochun DL, Hutton RD, Coles Ga, Wiшамs JD. Coagulation studies and fistula blood flow during erythropoietin therapy in haemodialysis patients. Nephrol Dial Transplant 1991; 6: $862 \cdot 867$.

Mandel SR, Martin PL, Blumoff RL, Mattern WD. Vascular access in a university transplant and dialysis program; results, costs, and manpower implications. Arch Surg 1977; 112: 1375.1380.

marx aB, landmann J, Harder FH. Surgery for vascular access. Current Problems in Surgery 1990; 27: 28-29. 


\section{Literature}

May J, Tuler D, Johnson J, Stewart J, Ross Sheil AG. Saphenous vein arteriovenous fistula in regular dialysis treatment. $\mathrm{N}$ Engl J Med 1969; 280: $770-771$.

Middeleton WD, Picus DD, Marx MV, Melson GL. Color Doppler sonography of hemodialysis vascular access: Comparison with angiography. AJR 1989; 152: 633-639.

Monnens LAH, Donckerwolcke RamG, Ploos van Amstel SLB, Ten Velden GHM, Wotp ED. Children with terminal renal failure in the Netherlands 1979- 1986. Ned Tijdschr Geneeskd 1989; 133: 1364-1366.

Móler. Wiefel. H. Graft AV fistulas. In Progress in access surgery, Tordoir JHM, Kitslaar PJEHM, Kootstra G. eds. Maastricht: Datawyse, 1990: 1417.

Moller Wieffel H, Haug M. Zur Frage des geeigneten Gefässersatzes in der Dialyse Shunt Chirurgie. Angio 1983; 5: 199-209.

Netheriands Central. Bureau of Statistics. Pocket Yearbook 1988. The Hague: Staatsuitgeverij 1988.

Norusis MJ. Statistical Package for Social Sciences 4.0 Manual Chicago: SPSS Inc., 1990.

OTA K. An atlas of vascular access. Edinburgh: Churchill Livingstone, 1987.

OтA K. The patency rate of various blood accesses. In: Ota K, (ed) An atlas of vascular access. Edinburgh: Churchill-Livingstone, 1987: 167-170.

Palder SB, Kirkman RL, Whittemore AD, hakim RM, Lazarus JM, Tilney NL. Vascular access for hemodialysis: patency rates and results of revision. Ann Surg 1985; 202: 235.239.

Porter JA, Sharp WV, Watsh EJ. Complications of vascular access in a dialysis population. Current Surgery 1985; 42: 298-300.

Quinton W, Dillard D, Scribner BH. Cannulation of bloodvessels for prolonged hemodialysis. Trans Am Soc Artif Intern Organs 1960; 6: 104 . 113. 
Ramirez O, Swartz C, Onesti G, Marloux L, Brest AN. The winged in line shunt. Trans Amer Soc Artif Intern Organs 1966; 12: 220-221.

ReILY DT, WOOD RFM, BEu PRF. Arteriovenous fistulas for dialysis: Blood Flow, Viscosity, and long-term patency. World J Surg. 1982; 6: 628-633.

ReIuY DT, WOOD RFM, BEu. PRF. Prospective study of dialysis fistulas: Problem patients and their treatment. Br J Surg 1982; 69: 549.553.

ROBERTS AC, VALI K, BOOKSTEIN JJ, HVE RJ. Pulse-spray pharmacomechanical thrombolysis for treatment of thrombosed dialysis access grafts. Am I Surg 1993; 166: 221-226.

Rubio PA, FArreu. EM. Atlas of Angioaccess Surgery. Chicago: Year Book Medical Publishers, 1983.

RUTHERFORD RB. Standards for evaluating results of interventional therapy. Circulation $1991 ; 83$ [suppl I] : 6-11.

Rutherford RB, Fianigan DP, Gupta SK, Johnston KW, Karmody A, Whitemore AD, Baker JD, Ernst CB, Jamieson C, Memta S. Suggested standards for reports dealing with lower extremity ischemia. J Vasc Surg $1986 ; 4: 80-94$.

Sabanayagam P, Schwartz AB, Soricelli RR, Chinttz JL, Lyons P. Experience with one hundred reinforced expanded PTFE grafts for angioaccess in hemodialysis. Trans Am Soc Artif Intern Organs 1980; 26: 582-583.

Saerd M, Newman Ga, Mc Cann RL, Sussman SK, Braun SD. Stenoses in dialysis fistulas: Treatment with percutaneous angioplasty. Radiology 1987; 164: 693.697.

Schulz V, Zehle J, Kindler J, Sieberth HG. DipyridamolAzetylsalizylsäure zur Prophylaxe von Shunt-Thrombosen bei chronischen Dialysepatienten. Nieren-und Hochdruckkrankheiten 1981; 10:49-52.

Schwab SJ, Raymond JR, Saefd M, Newman GE, Dennis Pa, Randal. Bollinger R. Prevention of hemodialysis fistula thrombosis. Early detection of venous stenoses. Kidney Int 1989; 36: 707-711. 
Scribner BH, Caner JEZ, Burı R, Quinton W. The technique of continuous hemodialysis. J Am Soc Artif Int Organs 1960; 6: 88-103.

Shamdon S, Chindussi L, Higgs B. Hemodialysis by percutaneous catheterization of femoral artery and vein with regional heparinisation. Lancet $1961 ; 2: 857-859$.

SINGER A. The external arteriovenous silastic cannula shunt. In: Haimov M, ed. Vascular Access. New York: Futura Publishing Company 1987: 25-39.

Stoof MJH. Secondary access surgery for hemodialysis and chemotherapy [Dissertation]. Groningen, 1981.

Smits PJH, Slooff MJH, Lichtendahl DHE, Van Der Hem GK. The Biocarbon vascular access device (DiaTAB) for hemodialysis. Proc EDTA 1984; 21: 267.269 .

Stakt RP, Brom HLF. Homologous venous grafts for access surgery. In: Progress in surgery. Tordoir JHM, Kitslaar PJEHM, Kootstra G. eds. Maastricht: Datawyse, 1990: 22-25.

Surratt RS, Picus D, Hicks ME, Darcy MD, Kieinhoffer M, Jendrisak M. The importance of preoperative evaluation of the subclavian vein in dialysis access planning. AJR 1991; 156: 623-625.

TAPSON JS. Temporary vascular access in British hemodialysis units. Artif Organs $1985 ; 9: 239-242$.

Taylor Je, Mclaren M, Henderson IS, Belch JJF, Stewart WK. Prothrombotic effect of erythropoietin in dialysis patients. Nephrol Dial Transplant 1992; 7: $235 \cdot 239$.

Tesio F. A two catheter internal jugular vein cannulation: For long.term vascular access for hemodialysis. 38th Annual ASAIO Meeting, 1992 , Nashville, TN, USA. 
TorDoIr JHM. Noninvasive diagnostic studies of arteriovenous fistulas for hemodialysis [Dissertation]. Maastricht, 1989.

Tordorr JHM, Krtslan PJEHM, Kootstra G, eds. Progress in Access Surgery, Proceedings of the 2nd International Congress on Access Surgery, Maastricht 1990. Maastricht: Datawyse, 1990.

Tordotr JHM, Herman JMMPH, Kwan TS, Diderich PM. Long-term follow. up of the polytetrafluoroethylene (PTFE) prosthesis as an arteriovenous fistula for hemodialysis. Eur J Vasc Surg 1988; 2: 3-7.

Turmel Rodrigues L, Pengloan J, Blanchier D, Abuza M, Birmele B, Hallot O, BLANCHARD D. Insufficient dialysis shunts: Improved long-term patency rates with close hemodynamic monitoring, repeated percutaneous balloon angioplasty, and stent placement. Radiology 1993; 187: 273.278.

Twardowskı ZJ. How will chronic dialysis change over the next decade? Seminars in Dialysis 1991; 4: 231-232.

Valenta J, Bilfk J, Opatrnky $K$. Autogenous saphenous vein graft as secondary vascular access for hemodialysis. Dial Transplant 1985; 14: 567.571 .

Van den Brand $M$, Van Halem C, Van den Brink F, De Feyter P, Serruys P, Suryapranata H, Meeter K, Bos E, Van Dalen FJ. Comparison of costs of percutaneous transluminal coronary angioplasty and coronary bypass surgery for patients with angina pectoris. Eur Heart J 1990; 11: 765-771.

Vanherweghem Jl, Yassine $T$, Goldman M, Vandenbosch G, Delcour C, Strurven J, Kinnaert P. Subclavian vein thrombosis: a frequent complication of subclavian vein cannulation for haemodialysis. Clin Neph 1986; 25: $235-238$.

VANHOLDER V, HOENICH N, RINGOIR S. Morbidity and mortality of central venous catheter hemodialysis: A review of ten years experience. Nephron $1987 ; 47: 274.279$.

Wehrli H, Chenevard R, Zaruba K. Chirurgische Eifahrungen mit arteriovenöse Haemodialyse-Shunts (1970-1988). Helv Chir Acta 1989; 56: 621-627. 


\section{Literature}

WHITE GH, MAY J. Use of autogenous vein for fistulas and interpositional grafts. In: Vascular access surgery, Wilson ed., 2nd ed. Chicago: Year book Medical Publishers, 1988: 263-272.

WIIson SE. Vascular Access Surgery. 2nd ed., Chicago: Year Book Medical Publishers, 1988.

Zibari GB, Rohr MS, landreneau MD, Bridges RM, Devault Ga, Petty FH, Costley KJ, Brown ST, McDonald JC. Complications from permanent hemodialysis vascular access. Surgery 1988; 104: 681-686.

Zutstra JI, SCholten AP, KuChert SA, Burger H. First results of percutaneous transluminal angioplasty of Scribner shunts and Cimino fistulas. Journal of Medical Imaging 1987; 1: 155-159.

Zuıstra J. Percutaneous transluminal angioplasty in vascular access for hemodialysis. A manual for the radiologist [Dissertation]. Utrecht, 1989. 


\section{DANKWOORD}

Het verschijnen van dit proefschrift geeft mij de gelegenheid om vele mensen te bedanken die er toe hebben bijgedragen. Goede contacten en vriendschappen zijn voortgekomen uit het werk aan dit proefschrift.

Aan mijn leraren aan het Stedelijk Gymnasium te Utrecht en mijn leermeesters aan de Rijksuniversiteit te Leiden bewaar ik zeer goede herinneringen. Zij legden de grondslag voor mijn medische vorming, waarop dit werk stoelt.

Mijn leermeester in de chirurgie, dr. M.W. van Weel, opleider in het Gemeenteziekenhuis aan de Bergweg te Rotterdam, gedenk ik met dankbaarheid. Zijn integere karakter, zijn nauwkeurige techniek en ook zijn oog voor de grenzen van de heelkunde leidden tot uitstekende resultaten en waren het navolgen waard.

Prof. Kootstra, beste Gauke, in Groningen heb ik je voor het eerst leren kennen, toen je me rond leidde op de transplantatieafdeling. Je enthousiasme en hartelijkheid zijn een inspiratie geweest bij het tot stand komen van dit werk. Je kennis van en gevoel voor de vasculaire toegangschirurgie hebben dit proefschrift vorm gegeven.

Prof. Kitslaar, beste Peter, je heldere en systematische aanpak van de problemen die zich voordoen bij het beschrijven van deze tak van vaatchirurgie is een grote hulp geweest.

Dr. Kluchert, beste Bert, je enthousiasme voor de dialyse en een goede toegangs chirurgie en je doordachte registratie van gegevens in het door jou gemaakte computerprogramma voor de dialyse zịn onmisbaar ge weest.

Drs. Scholten, beste Alie, vanaf 1971, toen je uit Groningen aankwam en je de leiding van de dialyse affleling overnam van dr. Bouke Hazenberg, de stichter van de dialyseafdeling, heb je de afdeling en ons allen hoge maatstaven van werk bijgebracht.

Dr. de Jong, beste Gị̣s, jij hebt, uit de Groningse en Leuvense school stammend, weer een nieuwe dimensie aan de afḍeling toegevoegd. In het laatste jaar heb je constructief mee willen denken bij de afwerking van het proefschrift. 
Voor de nefrologen was het vanzelfsprekend dat toegangschirurgie in de nauwste samenwerking tussen nefroloog en chirurg en later ook radioloog plaats zou vinden. Deze samenwerking werd gekenmerkt door wederzijdse aanmoediging en zelden door verwijten.

Dr. Zijlstra, beste Jan, je inventiviteit bij het dilateren van shunts en je onvermoeide inzet, die al uitmondde in een voortreffelijk proefschrift over de percutane transluminale angioplastiek bij de toegang tot de bloedbaan voor hemodialysis heeft het beschrijven van de resultaten van de toegangschirurgie in ons ziekenhuis zinvol gemaakt. Een consequent toegepaste nieuwe methode kon vergeleken worden met de algemeen gangbare methode. Zonder de goede en vriendschappelijk verhoudingen die wij daarbij hadden was dat waarschijnlijk niet gelukt.

De leden van mijn chirurgische maatschap wil ik danken voor hun vriendschap en de tijd die zij mij hebben willen geven om dit proefschrift tenslotte tot een goed einde te brengen.

Niet allen die hebben bijgedragen tot dit proefschrift kan ik noemen, maar met name wil ik mijn medeauteurs vermelden dr. Frank de Charro, prof. dr. Cees van Halem, drs. Pieter Heesters, ir. Pieter Leffers en dr. Dirk Ubbink, die een aanzienlijke hoeveelheid tijd en aandacht hebben willen geven. Hen dank ik zeer. Patricia Falger heeft een belangrijk aandeel gehad met haar "language editing" en Erik Beenen met zijn tekeningen. Marina de Lint heeft menig uur besteed aan het intelligent inbrengen van de acces gegevens in het computerbestand.

De leden van de beoordelingscommissie: Prof. dr. J.P. van Hooff (voorzitter), Dr. A. Ament, Prof. dr. B. Janevski, Prof. dr. R.A. Janknegt en Prof. dr. H. van Urk dank ik voor hun bereidwilligheid het proefschrift te beoordelen en voot hun commentaar.

Ook wil ik wèl de patiënten noemen, die vaak met grote moed het leven met nierfunctievervanging dragen en daarbij de zorgen om hun shunt. Geen dialyse is denkbaar zonder de bijzondere verpleging, die daarbij hoott. De verpleegkundigen van de dialyseafdeling en allen die werken op de operatieafdeling, die zo'n grote rol spelen bij de zorg voor de shunts, verdienen een ereplaats in dit dankwoord.

Mijn kinderen en vooral mị̣n vrouw hebben de lasten mee moeten dragen van de talloze uren die de toegangschirurgie vraagt, vaak op ongelegen tijden. Het maken van dit proefschrift hebben zij vaak gesteund, soms verdragen, met meer of minder plezier, maar ook zij hebben volgehouden. Cobie, Pim, Hens, Kees en Marjon \& Ronald, dit proefschrift is mede jullie werk. 


\section{CURRICULUM VITAE}

De schrijver van dit proefschrift werd geboren op 2 augustus 1934 te Alkmaar. Hij was leerling van het Stedelijk Gymnasium te Utrecht, waar hij in 1952 eindexamen gymnasium \& deed. In 1961 legde hij het artsexamen af aan de Rijksuniversiteit te Leiden. Zijn opleiding in de chirurgie kreeg hij op de chirurgische afdeling van het Gemeente Ziekenhuis aan de Bergweg te Rotterdam (opleider dr. M.W. van Weel). $\mathrm{Na}$ zijn registratie als chirurg in 1967 was hij chef de clinique in hetzelfde ziekenhuis tot hij zich in 1970 vestigde te Dordrecht in het Diakonessenhuis Refaja. Nu werkt hij in dat zelfde, inmiddels door fusie vergrote ziekenhuis, het Drechtsteden Ziekenhuis, in maatschapsverband met W.F. Blom, dr. W.L.E.M. Hesp, dr. C. Mahabier, M. de Mos, dr. B. van Ooijen, L. Stam en dr. O.C.M. Varin. 

ENQUETE NAAR DE TOESTAND VAN DE ACCESS-CHIRURGIE IN DE NEDERLANDSE CENTRA VOOA CHRONISCHE HEMODIALYSE OP 31 DECEMBER 1987.

Codenummer centrum

Hoołd Dialyse aldeling

Naam van de invuller van de enquete
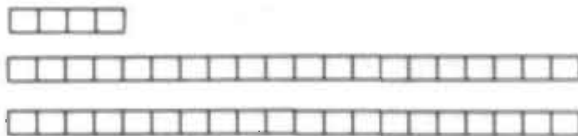

1. Hoeveel patienten zijn er met nierfunctievervangende behandeling op Uw afdeling? HOEFT NIET BEANTWOORD TE WORDEN (RENINE-ENQUETE)

2. Hoeveel patienten met nierinsulficientie worden met hemodialyse behandeld op de peildatum? HOEFT NIET BEANTWOORD TE WORDEN (RENINE-ENQUETE)

3. Hoeveel patienten hebben een arterio-veneure fistel (A.V fistel) volgens Cimino?

Toelichting

Bij patienten met meer functionerende shunts

Alle A-V shunts tellen.

$4 \quad H o e v e e l$ patienten heben een A-V shunt volgens Scribner?

5. Hoeveal patienten hẹben een primaire loegang iọ de bloedbaan?

(zie toelichting)

Toelichting

Onder primarre toegang wordt verstaan een $\mathbf{A}-\mathbf{V}$ fistel volgens Cimino en een A-V shunt voigens Scribner, tenxij de laatste wordi aangelegd omdat de primaire toegangen gefaald hebbenn, of onmogelijk zijn

6. Hoeveel patienten hebben een secundaire toegang tot de bloedbaan? (zie toelichting)

Toelichting

Onder secundaire toegang worth verstaan de toegangschirurgie vermeld onder vraag 7 .

7. Hoeveel patienten met een secundaife toegang toi de bloedbaan hebben 1 Vaatiransplantaten
la Autologe venien
ib Homologe venen
1 b1 Vascogref
1 b2 Dardik
ib3 overige
1c Heterologe vaten
1c1 Bovine
1c2 overige
PTFE

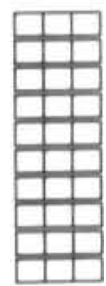


2. A. $V$ fisteis in de elleboogsholte

3. Scribner shunts (secundaire d.w.z omdat andere shunts faalden)

4 Bijzondere vormen?

4a Biocarbon

4b Hemasite

$4 c$ overige

8. Hoeveel patienten worden met de single needle methode behandeld

1 incidenteel

2. Als routine voor een langere periode?

9 Voor welke toegangsweg(en) wordt gekozen wanneer iemand gedialyseerd moet worden terwijl de permanente toegang tot de bloedbaan uitgevallen is of er nog geen permanente toegang is? (geschatte percentages)
1. Subclavia catheter
2 Shaldon (lies)catheter
3. Scribner shunt
4 Andere methode

Wordt bij stenoses by $A-V$ fistels en shunts de percutane transluminale angioplastiek (P.T.A), de techniek volgens Dotter, toegepast?
1 Incidenteel
2. Regeimatig
3. Nooit
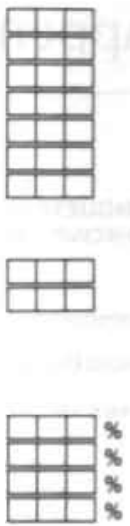

Wordt de toegangschirurgie uitgevoerd door (geschatte percentages)
1 eèn chirurg
2 enkele vaste chirurgen
3 ieder van de chirurgen
4 assistenten

Is hot mogelijk het aantal operatieve interventies voor access-chirurgie voor alle patienten per jaar op te leveren zonder veel moette?

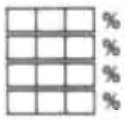

Zo ja, hoe groot is dat getal

13 Stemt $U$ toe in het door de Stichting Renine aan ons ter beschikking stellen van de hierboven on hieronder mot name genoemde gegevens? Wij vestigen or de aandacht op dat de gegevans anoniom gemaakt worden per patient en per centrum

\title{
haindiekening
}

stempel of naam in blokletters

\begin{abstract}
Vant ieder van de patientien zijn de volgende gegevens van belang leeftıj, geslacht, aantal doorgemaakte transplantaties an de vrang of zij aan diabeies mellitus lijden. Het aantal patienten in thuisdialyse wordt gevraaghd Deze gegevens zijn doer de Stichting RENINE verzameid en zouden wij graag bij het onderzoek gebruiken
\end{abstract}

\section{De gegevens worden zowel per patient als per centrum anoniem gemaakt}




\section{Shuntcontrole}

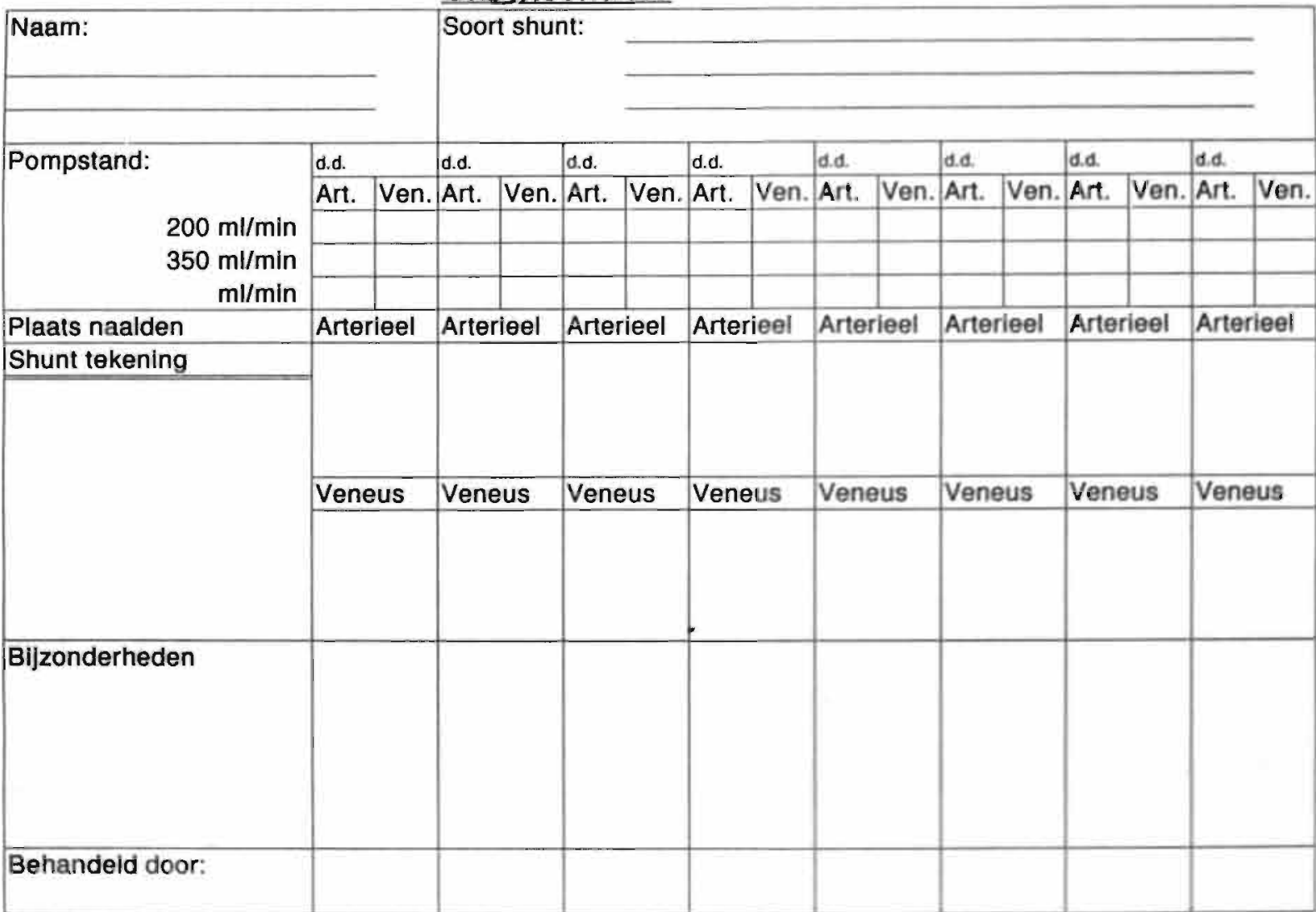




\section{COLOFON}

Omslag : Onrwerp Cobie Burger-Speelpenning

Tekeningen : Erik Beenen

Foto : Renée Zeegers Nieuwendijk Hoek

Lettertype : Garamond

Drukker : ICG Printing, Dordrecht

Binder : Drechtwerk Grafisch Centrum, Dordrecht 

